IZA DP No. 5357

Great Expectations: Law, Employment Contracts, and Labor Market Performance

W. Bentley MacLeod

December 2010 


\title{
Great Expectations: Law, Employment Contracts, and Labor Market Performance
}

\author{
W. Bentley MacLeod \\ Columbia University \\ and IZA
}

\section{Discussion Paper No. 5357 \\ December 2010}

\author{
IZA \\ P.O. Box 7240 \\ 53072 Bonn \\ Germany \\ Phone: +49-228-3894-0 \\ Fax: +49-228-3894-180 \\ E-mail: iza@iza.org
}

Any opinions expressed here are those of the author(s) and not those of IZA. Research published in this series may include views on policy, but the institute itself takes no institutional policy positions.

The Institute for the Study of Labor (IZA) in Bonn is a local and virtual international research center and a place of communication between science, politics and business. IZA is an independent nonprofit organization supported by Deutsche Post Foundation. The center is associated with the University of Bonn and offers a stimulating research environment through its international network, workshops and conferences, data service, project support, research visits and doctoral program. IZA engages in (i) original and internationally competitive research in all fields of labor economics, (ii) development of policy concepts, and (iii) dissemination of research results and concepts to the interested public.

IZA Discussion Papers often represent preliminary work and are circulated to encourage discussion. Citation of such a paper should account for its provisional character. A revised version may be available directly from the author. 
IZA Discussion Paper No. 5357

December 2010

\section{ABSTRACT \\ Great Expectations: Law, Employment Contracts, and Labor Market Performance}

This chapter reviews the literature on employment and labor law. The goal of the review is to understand why every jurisdiction in the world has extensive employment law, particularly employment protection law, while most economic analysis of the law suggests that less employment protection would enhance welfare. The review has three parts. The first part discusses the structure of the common law and the evolution of employment protection law. The second part discusses the economic theory of contract. Finally, the empirical literature on employment and labor law is reviewed. I conclude that many aspects of employment law are consistent with the economic theory of contract - namely, that contracts are written and enforced to enhance ex ante match efficiency in the presence of asymmetric information and relationship specific investments. In contrast, empirical labor market research focuses upon ex post match efficiency in the face of an exogenous productivity shock. Hence, in order to understand the form and structure of existing employment law we need better empirical tools to assess the ex ante benefits of employment contracts.

JEL Classification: J08, J33, J41, J5, K31

Keywords: employment law, labor law, employment contract, employment contract, law and economics

Corresponding author:

W. Bentley MacLeod

Columbia University

Department of Economics

420 West 118th, MC 3308

New York, NY 10027-7296

USA

E-mail: bentley.macleod@columbia.edu

\footnotetext{
* I am grateful to Janet Currie, Harold Demsetz, Victor Goldberg, Lance Liebman, and seminar participants at the Columbia Law School Faculty seminar and the American Law and Economics Association meetings for helpful discussions and comments. I am also grateful to Elliott Ash, Wil Lim, and Uliana Logina for invaluable research assistance.
} 
"Now, I return to this young fellow. And the communication I have got to make is, that he has great expectations."

"Take nothing on its looks; take everything on evidence. There's no better rule."

- Charles Dickens, Great Expectations

\section{Introduction}

New jobs and relationships are often founded with great expectations. Yet, despite one's best efforts, jobs and relationships may end prematurely. These transitions might be the result of an involved search for better opportunities elsewhere, or in the less happy cases they may stem from problems in the existing relationship. These endings can be difficult, especially when parties have made significant relationshipspecific investments. The purpose of this chapter is to review the role that employment and labor law play in regulating such transitions. This body of law seeks a balance between the need to enforce promises made under great expectations and the need to modify those promises in the face of changed circumstances.

The chapter's scope complements the earlier chapter on labor-market institutions in Volume 3 of this handbook by Blau and Kahn (1999). That chapter focused on policies affecting wage-setting institutions. Like much of modern empirical labor economics, Blau and Kahn (1999) use the competitive model of wage determination as the central organizing framework. Economists begin with the competitive model because it provides an excellent first-order model of wage and employment determination. The competitive model assumes that wages reflect the abilities of workers as observed by the market; this information, combined with information about a worker's training, provides sufficient information for the efficient allocation of labor.

Even if a labor market achieves production efficiency, it may nevertheless result in an inequitable distribution of income, as well as inadequate insurance for workers against unforeseen labor shocks. A number of institutions - such as a minimum wage, unions, mandated severance pay, unemployment insurance, and centralized bargaining - are viewed as ways to address these inequities and risks. Given that a competitive market achieves allocative efficiency, then these interventions necessarily result in allocative inefficiency. Hence, the appropriate policy entails a trade-off between equity and efficiency. For example, Lazear (1990) views employment law as the imposition of a separation cost upon firms wishing to terminate or replace workers. From this perspective, the policy issue is whether or not the equity gains from employment law are worth the efficiency costs. Many policymakers, such as the OECD and the World Bank, have taken the view that these employment regulations have for the most part gone too far-that they restrict the ability of countries to effectively adjust to economic changes and make workers worse off in the long run. ${ }^{1}$

\footnotetext{
${ }^{1}$ See the influential Jobs Study by the OECD (1994) and the recent work by the World Bank economists Djankov and Ramalho (2009).
} 
Notwithstanding the mainstream skepticism toward efforts to regulate the employment relationship, it remains true that some form of employment law has operated in every complex market society for at least the last 4000 years - for example, the first minimum wage laws on record date back to Hammurabi's code in $2000 \mathrm{BC}$. This chapter therefore takes a somewhat different perspective, drawing upon the literature in transaction-cost economics pioneered by Coase (1937), Simon (1957), and Williamson (1975), as well as the work on law and institutions by Posner (1974) and Aoki (2001). This research on the economics of institutions, like empirical labor economics, begins with the hypothesis that long-lived institutions are successful precisely because they are solving some potential market failure. Accordingly, this chapter is organized around the following question: How can labor-market institutions be viewed as an efficient response to some market failure? Just as the competitive-equilibrium model supposes that wages are the market's best estimate of workers' abilities, the institutional-economics program views successful institutions as solving a resource-allocation problem.

This approach does not assume that these institutions are perfect. On the contrary, just as the competitive model yields predictions regarding how wages and employment respond to shock, the hypothesis that institutions efficiently solve a resource-allocation problem generates predictions regarding the rise and fall of these institutions. Important precursors to this approach are found in labor economics. In a classic paper, Ashenfelter and Johnson (1969) suggest that we should be able to understand union behavior, including the strike decision, as the outcome of the interaction between several interested parties. The work of Card (1986) demonstrates that observed contracts cannot be viewed as achieving the first best, and hence transaction costs are a necessary ingredient for understanding the observed structure of negotiated employment contracts. Despite this early progress, the literature I review is still undeveloped. We do not have a good understanding of how the law works, nor do we understand the impact of legal rules on economic performance. In an effort to summarize what is known, this review is divided into three sections that correspond to coherent bodies of research.

Section 2 briefly reviews the structure of employment law and discusses some exemplary cases. A full review of employment law is not provided-for an excellent review, see Jolls (2007). My more modest goal is to provide some relevant insights into what law is and how it works. This sort of targeted inquiry is desirable because the standard assumption in economics is that the law enforces contracts as written. In practice, private law imposes no restrictions on behavior. It is mainly an adjudication system that can, after a careful review of the evidence, exact monetary penalties upon parties who have breached a duty. Hence, private law is a complex system of incentive mechanisms that affects the payoffs of individuals but does not typically constrain their choices. The distinction is important for economics because it is convenient to model legal rules as hard constraints on behavior-that is, as structuring the available moves in a game rather than just altering some of the expected payoffs. This approach also implies, wrongly, that rules apply equally to all individuals. Treating private law as an incentive system, instead, implies that the impact of the law is heterogeneous - an individual's response to a legal rule will vary with an individual's characteristics, such as wealth, attitudes toward risk, and the evidence that one can present in court. 
Heterogeneity and information also play key roles in the theory of employment contracts reviewed in Section 3 . The past forty years have witnessed tremendous progress in the economic theory of contract, especially in terms of teasing out how a particular set of parties should design a contract given the transaction costs characterizing the employment relationship. The influential principal-agent model, for example, was developed in the context of the insurance contract, which specifies state-contingent payments. ${ }^{2}$ The modern theory of contract, building on the work of Grossman and Hart (1986), recognizes that an important function of economic institutions and contracts is the efficient allocation of authority and decision rights within a relationship.

Most economists agree that unions and employment law affect the relative bargaining power of individuals. These institutions are usually interpreted as mere re-distribution of rents, and so any allocation of bargaining power that results in prices diverging from competitive levels is inherently inefficient. The modern literature on contract views authority as an instrument for mitigating transaction costs due to asymmetric information and holdup. This perspective also naturally admits a role for fairness in decision-making, and hence can provide an economic rationale for why fairness concerns are important in the adjudication of a dispute. $^{3}$

Section 3 also discusses the empirical content of these models. The modern empirical literature is concerned with identifying a causal link between various labor-market interventions and performance. Unfortunately, much of the economic theory of contract is not amenable to this approach. These models typically describe how matches with certain observable features ( $X$ variables) result in an employment-compensation package ( $Y$ variables). As Holland (1986) makes clear, these are not causal relationships, but merely associations. For example, the predicted relation between the sex of a worker and the form of his/her employment contract is not causal, since the sex of a worker is not a treatment variable.

This distinction is useful because it helps explain the gulf between much of the theory discussed in Section 3 and the empirical evidence discussed in Section 4. It is also worthwhile to keep in mind that all economic models are false. This does not imply that these models are not useful. As Wolfgang Pauli quipped regarding a paper by a young colleague - "it's not even wrong!" ${ }^{4}$ Rather, economic models are decision aids that guide further data collection and help in selecting between different policy interventions. The upshot for empirical researchers is that one typically tests the associations that the theory predicts, rather than the theory itself. Empirical determinations of the validity of these associations can help us decide whether and to what extent we can rely on the model as a decision aid.

The theory section discusses how contract theory can be used to understand employment law, and the conditions under which it may be desirable. We begin with a discussion of how contract design is affected by the interplay between risk, asymmetric information and the holdup that arises from the need for parties to make relationship specific investments. These models can be used to explain the role of the courts in

\footnotetext{
${ }^{2}$ See Pauly (1968).

${ }^{3}$ See ? for a fuller discussion of this point.

${ }^{4}$ See Peierls (1960). It is also worthwhile to point out that even though Newtonian physics is false, it is all that one needs for most practical applications.
} 
enforcing the employment contract. The recent property rights theory of the firm developed by Grossman and Hart (1986) illustrates the importance of governance and the associated allocation of decision rights in order to achieve an efficient allocation. ${ }^{5}$ A contract is an instrument that explicitly allocates certain decision rights between the contract parties. This can also be achieved with unions. This section discusses how the appropriate allocation of power and decision rights can enhance productive efficiency. Thus, these theories provide conditions under which union power may enhance productive efficiency, as suggested by Freeman and Medoff (1984).

Section 4 reviews the empirical evidence on employment and labor law. Here we are concerned with explicitly causal statements such as the question of whether or not a reduction in dismissal barriers will reduce unemployment. This is a causal inquiry because it compares the outcomes from two different choices: having more or less employment protection law. Subsection 4.2 discusses the literature on unions that addresses two questions. First, does unionization of a workforce increases productive efficiency? Second, does unionization increase or decrease firm profits? Even if a union increases productive efficiency, if the increase in rents extracted by the unions is greater than the increase in productive efficiency, then profits would fall as a consequence, which in turn may lead to a decrease in unionization. The chapter concludes with an assessment of the evidence and a discussion of future directions for research.

\section{The Law}

"The law embodies the story of a nation's development through many centuries, and it cannot be dealt with as if it contained only the axioms and corollaries of a book of mathematics. In order to know what it is, we must know what it has been, and what it tends to become."

Oliver Wendell Holmes, The Common Law, 1881.

The purpose of this section is not to provide a comprehensive review of employment law. Rather, the goal is to provide a sense of how the employment law has developed so that one might better understand its impact on the employment relationship. ${ }^{6}$ In the United States, employment law is primarily the domain of the states. Section 4 reviews several empirical studies that have exploited the natural experiments resulting from variations in state laws to measure the impact of various laws on economic performance. Overlaying the state laws are a number of federal statutes affecting the employment relationship, including the National Labor Relations Act of 1935 (allowing workers to organize collective bargaining units), Fair Standards Act of 1938 (establishing minimum employment standards), Employee Retirement Income Security Act of 1973 (ERISA) (ensuring that employee benefits meet national standards), Occupational Safety and Health Act of 1970 (OSHA) (establishing minimum health and safety standards in the workplace), and Family and Medical Leave Act (establishing protections for leave related to personal sickness or family emergencies). These laws are enumerated in Table 1.

\footnotetext{
${ }^{5}$ See Hart (1995) for a full discussion of this approach.

${ }^{6}$ See Jolls (2007) for a survey of employment law, and Rothstein and Liebman (2003) for a more comprehensive review of US law. Gould IV (2004) provides an accessible discussion of American labor law, and how it differs from European labor law.
} 
Table 1: United States Employment Laws

\begin{tabular}{|c|c|c|c|}
\hline $\begin{array}{l}\text { Racial Discrim- } \\
\text { ination }\end{array}$ & $\begin{array}{l}\text { Civil Rights Acts of } 1866 \text {, } \\
1964\end{array}$ & 1866 & Bars racial discrimination by employers. \\
\hline Social Security & Social Security Act & 1935 & Distributes social security benefits to those of retirement age. \\
\hline $\begin{array}{l}\text { Minimum } \\
\text { Wage }\end{array}$ & Fair Labor Standards Act & 1938 & Establishes a minimum hourly wage. \\
\hline $\begin{array}{l}\text { Overtime } \\
\text { Rights }\end{array}$ & Fair Labor Standards Act & 1938 & $\begin{array}{l}\text { Requires that employers pay a higher wage for work exceeding } 40 \\
\text { hours a week. }\end{array}$ \\
\hline Child Labor & Fair Labor Standards Act & 1938 & Places limits on many forms of child labor. \\
\hline $\begin{array}{l}\text { Gender Dis- } \\
\text { crimination }\end{array}$ & Civil Rights Act of 1964 & 1964 & Prohibits gender-based discrimination. \\
\hline $\begin{array}{l}\text { Religious Dis- } \\
\text { crimination }\end{array}$ & Civil Rights Act of 1964 & 1964 & Prohibits discrimination against employees on the basis of religion. \\
\hline $\begin{array}{l}\text { Age Discrimi- } \\
\text { nation }\end{array}$ & $\begin{array}{l}\text { Age Discrimination in Em- } \\
\text { ployment Act }\end{array}$ & 1967 & Prohibits discrimination against workers above the age of 40 . \\
\hline $\begin{array}{l}\text { Workplace } \\
\text { Safety }\end{array}$ & $\begin{array}{l}\text { Occupational Safety and } \\
\text { Health Act }\end{array}$ & 1970 & Establishes minimum standards for workplace safety. \\
\hline $\begin{array}{l}\text { Good Faith Ex- } \\
\text { ception }\end{array}$ & $\begin{array}{l}\text { Fortune v. National Cash Reg- } \\
\text { ister Co., } 373 \text { Mass. } 96\end{array}$ & 1977 & $\begin{array}{l}\text { Provides for a wrongful discharge claim against employers violating } \\
\text { the common-law contract duty of good faith and fair dealing. }\end{array}$ \\
\hline $\begin{array}{l}\text { Public Policy } \\
\text { Exception }\end{array}$ & $\begin{array}{l}\text { Tameny v. Atlantic Richfield } \\
\text { Co., } 27 \text { Cal.3rd } 167\end{array}$ & 1980 & $\begin{array}{l}\text { Provides for a wrongful discharge claim against employers when the } \\
\text { discharge would be a violation of public policy, for example, when the } \\
\text { employee is fired for refusing to commit a crime. }\end{array}$ \\
\hline $\begin{array}{l}\text { Implied Con- } \\
\text { tract Exception }\end{array}$ & $\begin{array}{l}\text { Wooley v. Hoffmann-La Roch, } \\
99 \text { N.J. } 284\end{array}$ & 1985 & $\begin{array}{l}\text { Provides for a wrongful discharge claim against employers when an } \\
\text { employment contract is implied. }\end{array}$ \\
\hline $\begin{array}{l}\text { Sexual Harass- } \\
\text { ment }\end{array}$ & $\begin{array}{l}\text { Meritor Savings Bank v. Vin- } \\
\text { son, } 477 \text { U.S. } 57\end{array}$ & 1986 & $\begin{array}{l}\text { Recognizes sexual harassment as a violation of the Civil Rights Act of } \\
1964 .\end{array}$ \\
\hline Layoff Notice & $\begin{array}{l}\text { Worker Adjustment and Retr- } \\
\text { raining Notification Act }\end{array}$ & 1988 & Companies must give 60 days' notice before large-scale layoffs. \\
\hline $\begin{array}{l}\text { Whistleblower } \\
\text { Protection }\end{array}$ & $\begin{array}{l}\text { Whistleblower Protection Act } \\
\text { of } 1989\end{array}$ & 1989 & $\begin{array}{l}\text { Prohibits retaliation against employees for reporting illegal acts against } \\
\text { the federal government. }\end{array}$ \\
\hline $\begin{array}{l}\text { Disability Dis- } \\
\text { crimination }\end{array}$ & $\begin{array}{l}\text { Americans with Disabilities } \\
\text { Act }\end{array}$ & 1990 & Prohibits discrimination based on disability. \\
\hline $\begin{array}{l}\text { Pregnancy Dis- } \\
\text { crimination }\end{array}$ & Civil Rights Act of 1991 & 1991 & Probits discrimination against employees because they are pregnant. \\
\hline $\begin{array}{l}\text { Medical Leave } \\
\text { Protection }\end{array}$ & $\begin{array}{l}\text { Family and Medical Leave } \\
\text { Act }\end{array}$ & 1993 & $\begin{array}{l}\text { Requires employers to allow workers } 12 \text { weeks of unpaid medical leave } \\
\text { for certain medical conditions of themselves or close relatives. }\end{array}$ \\
\hline
\end{tabular}


While the primary concern of the present chapter is the United States, studies of employment law in other countries are also discussed. Blanpain (2003), for example, provides a comprehensive review of European law. As in the United States, European law is complicated by the fact that both individual countries and the European Parliament create rules that affect the employment relationship. More generally, all countries in the world have some system of employment laws, created and adapted to the circumstances of each jurisdiction.

One chapter cannot do justice to the dizzying complexity of the law across jurisdictions, even if attention were restricted to a narrow area such as employee-dismissal law. As the quote from Holmes Jr. (1881) illustrates, legal systems are complex systems that evolve over time to resolve the variegated disputes faced by parties of commercial transactions. To make sense of this complexity, I follow the lead of the law-andeconomics movement as epitomized in the work of Richard Posner, who argues that the law, especially the common law, has evolved over time to address the needs of individuals trading in a market economy. ${ }^{7}$ Posner (2003) explicitly poses the rhetorical question: "How is it possible, the reader may ask, for the common law-an ancient body of legal doctrine, which has changed only incrementally in the last century - to make as much economic sense as it seems to?"8

The claim is not that the entire body of rules and norms governing economic activity can be viewed as the solution to the problem of efficiently organizing economic activity. Rather, the claim is that individual rules have evolved to solve particular problems that appeared repeatedly before the courts. From this perspective flow some observations that may help explain the theoretical and rhetorical gaps between legal rule making, economic models of the labor market, and economic policy making. The advantage of the economic approach is that it allows one to explore the empirical implications of a simplified representation of the law. The disadvantage, particularly for purposes of economic policy analysis, is that the simplifying assumptions may miss key characteristics of the law that are important in practice.

This gap between law and economics is particularly salient in laws protecting employees from discharge, wrongful or otherwise. In economics, employment protections are typically modeled as a form of turnover costs, leading to the view that such laws probably interfere with an economy's efficient response to shocks. As a consequence, organizations such as the OECD (see OECD (1994)) have advocated reducing or abandoning employment protections. Recent work by Blanchard and Tirole (2008) addressing how France and other countries should design unemployment insurance and employment protection concludes that there is no role for the law beyond enforcing employment contracts.

Nonetheless, as a matter of law, there are no jurisdictions where courts enforce all privately agreed-upon contracts. Labor contracts with young children, for example, are almost universally prohibited. Generally speaking, there is a substantial gap between the law in practice and the law as represented in many economic models of employment. One reason for this gap is that legal practitioners rarely have any reason to use an explicitly economic approach to understand the form of a particular contract. Lawyers typically represent clients in cases after the fact; the question of why a legal rule exists is not important to them. The real issue

\footnotetext{
${ }^{7}$ See Ehrlich and Posner (1974), and also Posner's classic work, Economic Analysis of Law, now in its seventh edition.

${ }^{8}$ See pg. 252.
} 
is to predict how a judge will rule and then present the case so that their client will do as well as possible in what is essentially a negative-sum game between the plaintiff and defendant. In this game, the details of the law are crucial, but the reasons why they have a particular form are not usually relevant. ${ }^{9}$

In consequence, the concerns of the legal scholar are quite different from those of the economist, which in turn creates a gap between the law as it exists and the law as modeled in economics. ${ }^{10}$ The goal of the next two sections is to narrow that gap ever so slightly, at least in the context of employment regulation. The next subsection discusses the generic structure of the law. Even though legal rules vary greatly from jurisdiction to jurisdiction, the notion of law and how it works has some universal features. More specifically, Subsection 2.1 examines three well-known employment-law cases in the United States and the United Kingdom. These cases illustrate the complex problem faced by a judge in an employment dispute. Moreover, as these cases demonstrate, the courts are not passive agents; they play an active role in resource allocation. Consistent with the "Posnerian" perspective, the decisions in some cases can be viewed as enhancing economic performance.

\subsection{What is Law?}

The notion of a legal rule dates back at least as far as 2000 BC, with the Babylonians following Hammurabi's code and the Mesopotamians following the code of Urukagina. While some of these ancient edicts imply curious beliefs about causality, ${ }^{11}$ it is clear that the purpose of many of these rules is to modify or constrain human behavior. For as long as law has existed, its purpose has been to facilitate the efficient functioning of civil society.

The aforementioned codes even had room for what we would now call labor law. Hammurabi's code includes, for example:

- Minimum wage rules: "If any one hire a day laborer, he shall pay him from the New Year until the fifth month (April to August, when days are long and the work hard) six gerahs in money per day; from the sixth month to the end of the year he shall give him five gerahs per day."

- Liability rule: "If a herdsman, to whom cattle or sheep have been entrusted for watching over, and who has received his wages as agreed upon, and is satisfied, diminish the number of the cattle or sheep, or make the increase by birth less, he shall make good the increase or profit that was lost in the terms of settlement."

These are remarkable examples of how legal rules are created to regulate the employment relationship. That minimum wage rules persist to this day suggests that there are robust reasons for the existence of such rules.

\footnotetext{
${ }^{9}$ Furthermore, judges are often suspicious of economics arguments and statistical evidence — so economic arguments might even be counterproductive. See the discussion by Posner (2008) and Breyer (2009).

${ }^{10}$ See discussion in MacLeod (2007b).

${ }^{11}$ Hammurabi's code, Paragraph 2, decrees: "If any one bring an accusation against a man, and the accused go to the river and leap into the river, if he sink in the river his accuser shall take possession of his house. But if the river prove that the accused is not guilty, and he escape unhurt, then he who had brought the accusation shall be put to death, while he who leaped into the river shall take possession of the house that had belonged to his accuser."
} 
Recognizing this possibility, the law-and-economics approach seeks to explain the rules as solutions to welldefined market imperfections. Ostrom (2000), for example, has shown that many societies have developed efficient systems of rules and adjudication for regulating the use of common-pool resources, thereby avoiding the tragedy of the commons (Hardin (1968)). Ostrom observes that all successful commons-governance regimes consist of a set of rules that have the following features:

1. The rules are commonly known;

2. There are penalties for breaking rules that increase in intensity with the severity and frequency of violation;

3. There is an organization or an individual who is responsible for imposing penalties when informed; and

4. There is a process of adjudication when there are disagreements regarding whether an offense has occurred and what penalty should be imposed.

All organizations, including firms and families, have rule systems with these features. The economic analysis of such rule systems typically entails asking what set of rules would achieve an efficient allocation. ${ }^{12}$ In the common-pool-resource problem, for example, one seeks a set of rules ensuring that each person with access does not overuse the resource. Organizational economics tries to determine which systems of rules and compensation in firms or public entities ensure that agents reveal useful information and choose efficient levels of effort.

What distinguishes the law's rule system from a family's or organization's is not the existence of binding rules, but the sources of enforcement and adjudication. When we speak of a legal system, we mean the set of rules and associated penalties that are enforced by the state. ${ }^{13}$ As discussed above, however, the jurisdiction associated with a dispute is often poorly defined. Even when the jurisdiction is well-defined, disputes can often be decided by multiple judicial bodies (including private mediation and arbitration). Many countries, such as Italy and the United Kingdom, maintain a separate system of courts for ruling on employment disputes. In the United States, disputes regarding a collective-bargaining agreement may be brought before the National Labor Relations Board, employment disputes before a state court, and Title VII discrimination suits before a federal court.

To illustrate what we mean by a legal system (and employment law in particular), let us consider the proverbial worker-firm relationship. In the standard neoclassical model of employment, the worker agrees to supply $L$ hours of labor for a wage $w$. This can be viewed as a supply contract where the hours are, say,

\footnotetext{
${ }^{12}$ Determining the optimal system for selecting a course of action given the preferences of individuals, the technology of the environment, and the information available is the subject of mechanism design theory. See Jackson (2001).

${ }^{13}$ It is worth highlighting the fact that a set of written rules is not a requirement, nor even a defining feature of a legal system. In the Middle Ages, the subjects of a feudal lord faced a number of rules regulating their life on the manor, most of which were not written (Bloch (1961)); nonetheless, the set of rules was widely understood. Written rules do have good social consequences, however, by assisting with evidentiary issues and facilitating agreement among parties regarding the applicable rule. Inter-subjective agreement on the law is an important issue in modern labor law, as we shall see in the case of employee handbooks.
} 
consulting time. In that case, the relationship would be governed by contract law. The worker must supply $L$ hours, and the employer must pay $w L$ dollars.

Should the worker supply less than $L$ hours, the worker has breached the contract. Suppose that the firm has paid $P_{0}$ in advance, a common practice if the worker is, for example, a lawyer. Some sort of binding agreement is needed; otherwise, the worker would simply take the $P_{0}$ and try to find employment elsewhere. The question, then, is: What incentives does the worker have not to breach the agreement?

One possibility is the use of an informal enforcement mechanism. This would include firms' telling each other that the individual has breached, and hence should not be dealt with. ${ }^{14}$ Another alternative is to use physical violence against the individual, a common technique in the illegal drug trade and other black markets. ${ }^{15}$ While both enforcement systems are still widely used, societies have evolved more legalistic systems of adjudication for the simple reason that parties sometimes fail to perform even if they act in good faith. Enforcement systems that trigger punishment regardless of the reason for breach, such as violence among drug dealers, are simply not always efficient. ${ }^{16}$

In contrast, if the contract is viewed as a legally binding agreement, then the breach of contract by the worker gives the firm the right to seek damages in court. If the firm prevails, the court can order the worker to pay damages to the firm; if the worker refuses to pay, the court can still enforce the decision by ordering the seizure of the worker's assets.

The fact that contract breach leads to the right to file suit—as opposed to an automatic penalty-is a feature that distinguishes legal enforcement from other forms of rule systems, such as rewards within a firm. In the economics literature, it is common to view any agreement between parties that links future rewards to actions as a "contract." Jensen and Meckling (1976), for example, famously proposed that one should conceptualize a firm as a "nexus of contracts." If all contracts are enforceable at negligible cost, a reward system that promotes an employee for good performance and an agreement with an outside supplier to pay a bonus for sufficient quality are assumed to be equally enforceable. If employment contracts are enforceable at no cost, subject only to information constraints, then explaining contract form requires only that one carefully specify the environment and then use principal-agent theory to work out the optimal contract.

The difficulty, as Williamson (1991) observes, is that the law uses forbearance for transactions within a firm. Even if a firm promises a promotion, that does not confer a right upon the worker to sue the firm should the promotion not be offered. All dispute resolutions of this sort occur strictly within the firm, with no appeal to an outside legal authority available. A full discussion of the role of courts in such disputes must wait until the next subsection, but for now the relevant point is that for any contract between two legal persons (in our example, firm and consultant), both parties always have the right to seek damages in court should there be a breach of contract. ${ }^{17}$

That the decision to sue is discretionary implies that the same rule may have different effects depending

\footnotetext{
${ }^{14}$ Greif (1989) has some nice examples from the Maghrebi traders, who did write letters to each other in this regard.

${ }^{15}$ Naidu and Yuchtman (2009) document that criminal law, with punitive sanctions, was widely used to enforce employment contracts in 19th century England.

${ }^{16}$ See MacLeod (2007a) for discussion and proof of this point.

${ }^{17}$ See Kornhauser and MacLeod (2011) for a discussion of the concept of a legal person.
} 
on the characteristics of the parties of the contract. The characteristics of the parties might even be the most important factor in whether a lawsuit is filed. For example, suppose that a company has illegal discriminatory hiring practices. If the market is thick, with plenty of employment alternatives, potential employees may not find it worthwhile to bring suit against the company. In a less friendly employment market, if an individual believes he has been the victim of illegal discrimination and cannot find another job, he may bring suit. This point is illustrative of the fact that we will always find differences between a legal rule on paper and the same rule in practice. ${ }^{18}$

A second source of uncertainty is how the court will decide a case. In the case of the breaching consultant, the court has to make two decisions, each of which is prone to statistical error: 1) deciding whether a breach has occurred, and 2) if so, the damages to be paid. For damages, the general rule is that courts order expectations damages-namely, the losses associated with the worker's breach. An example of a formula that the court might use is:

$$
\begin{aligned}
\text { damages } & =P_{0}+w_{1} L-w L \\
& =\text { prepayment }+ \text { cost of replacement }- \text { promised wages not paid }
\end{aligned}
$$

Here $w_{1}$ is the wage for the replacement worker. The worker has to pay the costs associated with finding a replacement worker rather than the value of the work done, due to contract law's requirement that injured parties make every effort to mitigate losses arising from breach. The mitigation rule is mandatory, meaning that parties cannot contract around it. Employment law has many other mandatory rules; slavery is prohibited, for example, as is discrimination on the basis of race, age, or sex.

Expectation is not the only way to calculate damages from contract breach. In a famous paper on contract damages, Fuller and Perdue (1936) identified restitution and reliance as other possible measures of damages. ${ }^{19}$ Restitution damages, for one, are intended to put the firm into the same financial position —as if the contract had never been signed. In our consultant example, restitution damages would only require the worker to repay $P_{0}$. Matters are less clear if $P_{0}$ is paid to the worker so that he can buy passage to the job site and secure accommodation. Suppose upon arriving, the worker is injured and cannot perform his duties; the firm sues for breach. If the contract does not specify what happens in this contingency, a court may be asked to fill in the gaps in the agreement. Some other issues that might not be described in the contract (and which the court must adjudicate) include whether the injured worker may be fired or whether he must take out a loan to repay $P_{0}$.

Alternatively, the firm, in the expectation of being able to rely upon performance, may have paid for passage and accommodation. In that case, if the worker does not perform, then she may be asked to compensate the firm for these reliance expenditures.

\footnotetext{
${ }^{18}$ Dunford and Devin (1998) have a nice discussion of how employee perceptions affect the decision whether to file suit. For a review of the literature on the decision to file a suit, see Kessler and Rubinfeld (2007).

${ }^{19}$ This work has been influential in law and economics. Economists have used the three damages measures-expectations, restitution, and reliance - as alternative legal rules that can be analyzed using the standard tools of economics. See, in particular, Shavell (1984) and Rogerson (1984).
} 
Finally, the contract could have provided that a non-performing worker pay a fine $P_{0}$. In this case, nonperformance would not be a breach of contract, and a breach would occur only if the worker failed to pay back $P_{0}$. Notice that in this case, the damages would simply be $P_{0}$, even under the expectation-damages rule. This example illustrates that for the same exchange relationship there is no unique notion of contract breach. Rather, the contract defines what constitutes breach, and then the courts must decide whether or not to enforce the terms set out in the agreement. ${ }^{20}$

Defining the conditions for breach is not a clear-cut exercise. For example, the contract could have specified liquidated damages in the amount $P_{0}$. In this case, breach would occur for non-performance, but then the contract would direct the court to set damages at $P_{0}$. This contract seems to be equivalent to the previous one (indeed, most economic theories of contract would see them as equivalent), but there is an important distinction. In the previous case, if the worker pays $P_{0}$, no breach has occurred, and the firm has no right to bring suit against the worker. In the liquidated-damages case, even if the worker offers to pay $P_{0}$, the firm still has a right to sue the worker because technically a breach has still occurred. Admittedly, the firm would face an uphill battle in court if the worker had offered to pay-and normally would have no reason not to accept the offer as part of a settlement agreement-but the right exists nonetheless. The firm might believe, for example, that the worker abused the liquidated-damages clause, accepting the consulting job only as a contingency in case another opportunity did not work out. If the firm's belief is true, the worker has arguably violated the requirement of good faith and fair dealing — another mandatory rule in the common law of contracts. Arguing that the liquidated-damages clause no longer applies, the firm might ask for expectation damages larger than $P_{0}$.

Conversely, assume that the firm sets liquidated damages at three times $P_{0}$. Breach occurs, and the worker declares these damages to be unconscionably high. The worker may have a valid claim under contract law's prohibition against penalty clauses. This doctrine—another mandatory rule—provides that liquidated damages far exceeding the losses to the injured party will not be enforced by courts.

The prohibition on penalty clauses, along with the other examples of mandatory rules discussed above, illustrate that the law allows for a significant degree of judicial intervention into private contracts. Among other things, a court can fill in missing terms and refuse to enforce unreasonable terms. The decision whether to intervene is often at the court's discretion, but courts usually turn to the Uniform Commercial Code and other statutes, as well as previous court decisions, to justify these interventions. Thus the legal system is an adjudication process that modifies contracts in the face of a breach as a function of past experience and practice.

The extent to which courts should intervene into freely entered agreements has proven to be controversial. Early scholars, such as MacNeil (1974), proposed that courts rely on many sources of information, including industry custom and the history of the relationship between the plaintiff and the defendant, when making a decision. If parties have a longstanding relationship, Macneil argued, contract terms should be enforced within the context of the relationship. Macneil and many others believed that this sort of context-

\footnotetext{
${ }^{20}$ See MacLeod (2007a) for a discussion of whose reputational concerns interact with the breach decision. In particular, the theory predicts that the party whose reputation is the most valuable should be the one who is responsible for initiating breach.
} 
sensitive adjudication could help repair the parties' relationship and facilitate the continuation of mutually beneficial exchange. Most economic theories of contract, in contrast, work from the assumption that parties have well-defined interests and can draft agreements efficiently, implying that contracts should be enforced as written. This presumption has led to a law-and-economics scholarship that mostly argues for the curtailment of judicial discretion, and for a more systematic dependence upon basic economic reasoning when ruling on a case (see Goetz and Scott (1980) and more recently Schwartz and Scott (2003)).

Regardless of one's theoretical commitments, it remains the case that the law does not simply enforce a set of well-defined rules. The law does include a set of rules, but along with a system of adjudication that results in a context-sensitive application of these rules to individual cases. This context sensitivity includes, among other things, consideration for the idiosyncratic features of the parties. The basic principles of contract law apply to all agreements between two parties, but more specialized bodies of law have evolved to regulate specific classes of contracts. The insurance industry is regulated by a specialized area of contract rules (for example, see Baker (2003)), as is employment law. It is to this latter body of law that we now turn.

\subsection{Employment Law}

Employment law evolved from contract law and master-servant law to deal with the unique problems characterizing the modern employment relationship. The first task is to determine the difference between 1) a firm's relationship with an outside contractor selling services, and 2) its relationship with an employee. The difference not only affects the area of law that regulates the relationship, but it also affects the relevant tax law. In the United States, the Internal Revenue Service will find that an employment relationships exists when "the person for whom services are performed has the right to control and direct the individual who performs the services, not only as to the result to be accomplished by the work but also as to the details and means by which that result is accomplished." 21

As this tax regulation exemplifies, the obligation of the employee is to follow his employer's directions, not to produce a specific service with particular characteristics. Simon (1951)'s model nicely captures this distinction between sales and employment. In a sales contract, says Simon, the seller agrees to supply a particular good or service $x$ from the set of all possible goods and services $X$, and in exchange the buyer agrees to pay a sum $P$. An employment relationship, in contrast, is characterized by a subset of all possible goods and services, $A \subset X$, that represents the set of duties that the employer might ask the employee to carry out. $A$ might include the service $x$ defined in the aforementioned sales contract, but that single task would normally be just one component in a broad complex of obligations defining an employment relationship. In exchange for a promise to carry out these duties, the employer agrees to pay a wage $w$.

Simon's simple model highlights an essential feature of the employment relationship, namely, the admissible scope of a person's job as represented by the set $A$. The admissible set of tasks $S \subset X$-that is, the set of acts that an employer is allowed by law to command-has been subject to a plethora of regulation and litigation. For example, is it conscionable for a firm to require 50 hours a week? Can a manager ask her

\footnotetext{
${ }^{21}$ Treas. Reg. § 31.3121(d)-1(c)(2).
} 
assistant to commit crimes?

An employment relationship often begins with little formal agreement about the tasks the employee will be asked to carry out. The longer the potential duration of the employment, the more incomplete the initial employment agreement. Given the informal nature of such agreements, when disputes do arise the courts will have little to rely upon when constructing the obligations of each party. With poorly defined obligations, determining whether a breach occurred presents a difficult task, as does choosing an appropriate remedy.

The combination of extreme contract incompleteness and daunting litigation costs have convinced many legal scholars that the appropriate default rule is at-will employment. The courts have converged to this default rule partly because they now view employment law as an extension of contract law. That view diverges significantly from the early case law on employment disputes, which was mostly governed by "master-servant law." 22 That old body of law consisted of a set of legal default rules developed in England and the United States to deal with cases involving domestic servants. In the master-servant relationship, the customary period of employment lasted one year; courts held that neither party should sever the relationship before then.

In a widely cited work, Wood (1877) argued for replacing this law with the rule of at-will employment, where both parties can sever the relationship whenever they wish and face no liability beyond the requirement that the employer pay her employee the agreed-upon wage for work already completed. Wood's argument was a pragmatic one, based on the bad experiences of many employers and employees with the inflexibility of master-servant law. As detailed in Feinman (1978), the new rule was quickly adopted by the New York courts and remains the default rule today. In California, the legislature adopted what is now Section 2922 of the California Labor code, which provides that "employment, having no specified term, may be terminated at the will of either party on notice to the other."

The at-will-employment rule figures prominently in most economic models of the labor market. As these models have it, workers and firms enter into relationships that are preferred to the alternatives in the marketplace. Should a firm mistreat a worker, or have high standards for performance or number of hours worked, the firm will have to pay relatively high wages or else the worker will leave. Similarly, if a worker demands a higher wage or better working conditions, the firm is free to search for another worker who will abide by the current arrangements. In equilibrium, all firms and workers are satisfied with their lot relative to the alternatives.

The hypothesis of a perfectly competitive market can explain many broad features of wages and employment over time, but it cannot explain the emergence of the at-will-employment rule. This is an example of model's inability to explain the emergence of laws that seem to constitute reasonable responses to real economic issues. That failure indicates flaws in popular economic models—but not in economic reasoning generally. Consider the case of child labor. As societies have become more wealthy, they have gradually imposed stricter legal constraints on the minimum age and maximum hours for minors in the workplace. By the perfectly-competitive-market hypothesis, these restrictions would be unjustified because only those

\footnotetext{
${ }^{22}$ See Feinman (1978) for a review of the development of this law.
} 
families for which child labor is efficient would put their children to work rather than in school. On the other hand, a more realistic economic inquiry recognizes the market imperfection imposed by liquidity constraints: children (and parents) cannot borrow against future income arising from education, so many families send their children to work for a short-term gain in income rather than invest in a long-term gain from education. Investing in education results in superior overall welfare, so the choice to put children to work is inefficient. Laws that regulate child labor, like the Fair Labor Standards Act, are justified because, by increasing the cost of child labor, they motivate families to substitute education for labor. By increasing investments in education, these laws increase social welfare.

The analysis in the previous paragraph indicates the potential insight to be gained from an evolutionary perspective when investigating the law and economics of employment law. Applying this perspective to our law's historical origins, we observe that employment law adapts to the changing macroeconomic environment. One of the earliest labor statutes on record, the Ordinance of Labourers, addressed the problems of unharvested crops, rising wages, and poaching of workers faced by English landowners at the height of the Black Death. Similarly, in 1630, the Massachusetts General Court placed a wage cap of 2 shillings a day on skilled craftsmen, who were at that time taking advantage of limited supply. More recently, the Fair Labor Standards Act became law in the midst of the Great Depression, when workers lacked market power to ensure good working conditions. Mandatory overtime pay, meanwhile, incentivized firms to hire more workers at fewer hours each, thereby serving as an income- and risk-sharing function.

These legal adaptations to changes in the labor-market environment can all be conceived as forms of insurance, whether against the waste of unharvested crops, gouging by craftsmen, or unemployment. In the next subsection, we discuss recent work based on the hypothesis that workers are risk-averse, which might help explain some of the features of these laws. Certainly, both minimum-wage laws and unemployment insurance can be viewed as forms of imperfect insurance. ${ }^{23}$

Once the issue of risk is put aside, the law-and-economics movement has tended to take the view that employment at will is the optimal default rule (see, e.g., Epstein (1984)). Within economics, a tradition including Friedman (1962) and Alchian and Demsetz (1972) has viewed labor services from the perspective of the buyer-seller contract-with no remedies for contract breach. Specifically, Friedman argued that a competitive market with free entry and exit is the most efficient market form, even when contracts cannot clearly specify quality. In his vision of the world, workers and firms trade freely within the context of the sales contract (quality $x$ in exchange for price $p$ ); should performance be inadequate, the worker would gain a poor reputation and thereafter be excluded from the market.

There are two difficulties with this argument. The first, as MacLeod (2007a) discusses, is that the literature on relational contracts shows that reputational concerns are neither necessary nor sufficient to ensure efficient exchange. Second, the common law has developed many doctrines that limit the freedom of contract in the context of the simple buyer-seller model. Posner (2003) suggests that these developments tend to enhance contract performance. Chakravarty and MacLeod (2009) present evidence that this is indeed

\footnotetext{
${ }^{23}$ The reader is referred to Blau and Kahn (1999) and Rogerson et al. (2005) for excellent reviews of this literature.
} 
the case for a large class of contracts that are common in the construction industry.

As the Simon model highlights, the employment relationship is different because performance obligation is created ex post. If the worker accepts a contract with scope $A \subset X$, then the performance obligation is created when the employer asks the employee to carry out $x^{*} \in A$. If the relationship were governed by standard contract law, then if the employee chooses $x^{b} \neq x^{*}$ the employer-cum-buyer could sue for damages $B\left(x^{*}\right)-B\left(x^{b}\right)$, where $B(x)$ is the benefit to the employer of action $x$. Under employment at will the general rule would be that the employer has no right to sue, but she can freely dismiss the employee, even if performance is satisfactory.

Correspondingly, the employee has the right to leave whenever he wishes. For example, if the employer asks the employee to carry out an action outside the scope of his duties, then under at-will employment the employee has the right to refuse to carry out the task and find another job. In contrast, in the case of a construction contract, if the buyer were to ask for a modification to the building plan, then under U.S. law the contractor would have an obligation to carry out the modification, but he would also have the right to sue for the additional cost of the change if the buyer/builder does not adequately compensate him for the changes.

The defining feature of at-will employment is that in each period parties are free to renegotiate the contract, with the outside options defined by each parties' market opportunities. Consistent with the Coase theorem, we should expect at-will employment to give rise to arrangements that are ex post efficient. This observation has led some legal scholars (e.g., Epstein (1984)) to suggest that exceptions to employment at will are inefficient. Yet today in the United States, as in most other jurisdictions worldwide, the law of wrongful discharge is alive and well. Indeed, there are clear exceptions to the rule of employment at will. In the next section, we discuss three of the most important exceptions figuring in recent empirical work on employment law.

\subsection{Exceptions to Employment at Will}

This section discusses three exceptions to employment at will that have found broad support in U.S. courts. These exceptions are judge-made laws, created in response to difficult cases; hence, they are good examples of how the common law evolves in response to the disputes that arise in practice. The three exceptions we consider are 1) the public policy exception, protecting from employer retaliation those workers that act in a way consistent with accepted state policy, 2) the implied contract exception, protecting workers who can show that the implicit contract with the employer entails just-cause dismissal, and 3) the good-faith exception, requiring employers and employers to behave in ways consistent with fair dealing.

U.S. courts rarely order specific performance - that is, the losing employer typically still has the right to discharge the employee - and hence the issue is usually one of damages: How much should she have to pay for this right? In other jurisdictions, however, reinstatement is sometimes considered an acceptable remedy. One of the few U.S. cases in which specific performance was granted in an employment dispute was Silva 


\section{v. University of New Hampshire. ${ }^{24}$}

The question of damage awards is not straightforward, but economics can assist in organizing our thinking. If markets are perfectly competitive-and a worker's compensation is equal to his best market alternative-dismissal does not entail any harm. However, as Mincer (1962) has shown, the second assumption can break down when the worker's training costs were significant. If the worker paid for some of the training costs, he will be compensated for them through increased future compensation, and therefore his income may be in excess of the best market alternatives. More often, dismissal entails a costly job search and possibly relocation. When an employee has been wrongfully discharged, the court will award damages that reflect these costs.

An additional complication is whether the wrongful-discharge action comes under tort or contract law. The first exception to the at-will employment rule, a claim for wrongful discharge as violation of public policy, is considered a tort claim. ${ }^{25}$ A tort claim, put briefly, is distinguished from contract disputes by there being no requirement for a prior contractual relationship. Standard examples include traffic accidents and medical malpractice. The practical implication of this distinction is that tort law allows for the recovery of both consequential damages and punitive damages, which may far exceed the direct economic harm suffered by the discharged employee. In contract law, consequential damages and punitive damages are in general not recoverable.

\subsubsection{Public Policy Exception}

Under the public-policy exception, an employee may sue for wrongful discharge if he is dismissed for conduct that is protected by law. Miles (2000) summarizes the four types of terminations that fit under this class of exception. ${ }^{26}$ They are (1) "an employee's refusal to commit an illegal act, such as perjury or pricefixing"; (2) "an employee's missing work to perform a legal duty, such as jury duty or military service"; (3) "an employee's exercise of a legal right, such as filing a workman's compensation claim"; and (4) "an employee's 'blowing the whistle,' or disclosing wrongdoing by the employer or fellow employees."

A well-known example of the first type of public-policy exception is the 1980 case Tameny $v$. Atlantic Richfield Co. ${ }^{27}$ Plaintiff Tameny, the dismissed employee, claimed that his discharge resulted from a refusal to participate in the company's unlawful price-fixing scheme. Defendant Atlantic Richfield argued that since there was no employment contract, Tameny's employment was at-will and could be terminated at any time. The California Supreme Court ruled for Tameny, holding that an employer cannot discharge an employee for refusing to perform an illegal act. The court further held that the employee can recover under tort law, thereby allowing for potentially higher damages. On this last point, the moral distinction between tort and contract—specifically, that a breach is blameless, but a tort is wrongful—is relevant. Atlantic Richfield

\footnotetext{
${ }^{24} 888$ F.Supp. 293 (D.N.H. 1994) (granting a preliminary injunction preventing a tenured professor's suspension for comments that offended some students).

${ }^{25}$ See Rothstein and Liebman (2003), chapter 10.B.

${ }^{26}$ See page 78 .

${ }^{27} 27$ Cal.3rd 167 (Calif. 1980).
} 
did not just breach a contract, it retaliated against an employee for refusing to do its criminal dirty work. Consistent with our moral intuitions, the court considered the company's conduct to be morally wrongfulnot just business as usual—and therefore established a legal mechanism for increased punishment of such conduct.

Economic models of employment mostly ignore illegal activity on the part of employees, yet Tameny and other cases involving the public-policy exception clearly demonstrate that some employers do ask employees to commit crimes. The economic implications of this rule are difficult to tease out. In Tameny, at least, the employee was asked to engage in anti-competitive activity, so in this case the public-policy exception probably enhanced economic efficiency. But economic evaluations of public-policy cases are generally more difficult. If the illegal activity entails consumer goods, such as drugs or gambling, then the public-policy exception likely decreases output, albeit in a direction that arguably enhances social welfare. The prohibition against discharge for military service, meanwhile, reduces economic efficiency because it prevents the employer from finding a more productive replacement. As with the illegal-consumer-goods exception, the military-service exception to at-will employment arguably serves other social-welfare goals.

\subsubsection{Implied Contract Exception}

When a worker can verify that a permanent employment relationship is promised by his employer, such employment can no longer be regarded as at-will and can be terminated only under just cause. ${ }^{28}$ Under reigning court precedent in some states, if a personnel manual given to employees specifies that termination is only with cause, a binding contract exists. Woolley v. Hoffmann-La Roch was the first opinion to hold that employee handbooks can be part of a legally binding employment contract. ${ }^{29}$

The facts of Woolley are as follows. Plaintiff Richard Woolley was hired by defendant Hoffmann-La Roche, Inc. in 1969 as section head in one of defendant's engineering departments. The parties did not sign a written employment contract, but plaintiff received a personnel manual which read, in part, that "[i]t is the policy of Hoffmann-La Roche to retain to the extent consistent with company requirements, the services of all employees who perform their duties efficiently and effectively." In 1978, after Woolley's submission of a report on piping problems at one of defendant's buildings, defendant requested that he resign. Plaintiff refused, and he was fired.

The trial court judge held for the defendant on summary judgment. On Woolley's appeal, the New Jersey Supreme Court reversed and remanded the case for trial, holding that an employee's handbook could be evidence of a binding contract. The court couched its ruling in notions of fairness:

All that this opinion requires of an employer is that it be fair. It would be unfair to allow an employer to distribute a policy manual that makes the workforce believe that certain promises

\footnotetext{
${ }^{28}$ See, e.g., Toussaint v. Blue Cross \& Blue Shield, 292 N.W.2d 880 (Mich. 1980) ("When a prospective employee inquires about job security and the employer agrees that the employee shall be employed as long as he does his job, a fair construction is that the employer has agreed to give up his right to discharge at will... and may only discharge for cause").

${ }^{29}$ Woolley v. Hoffmann-La Roch, Inc., 499 A.2d 515 (N.J. 1985).
} 
have been made and then to allow the employer to renege on those promises. What is sought here is basic honesty: if the employer, for whatever reason, does not want the manual to be capable of being construed by the court as a binding contract, there are simple ways to attain that goal. All that need be done is the inclusion in a very prominent position of an appropriate statement that there is no promise of any kind by the employer contained in the manual...

In this case, as in many others, one party is not completely truthful with the other party. This possibility is ignored by most economic models of contract. Economists typically assume that both parties do what they say they will do, and if they do not, any malfeasance is anticipated by the other party. The Woolley opinion can be seen as requiring employers to comply with previous agreements not to engage in malfeasance. The judgment does not prohibit dismissal without cause; it simply requires that employers honor promises not to dismiss without cause.

Employee handbooks are not the only example of an implied contract. For example, Pugh v. See's Candies held that a long employment with regular promotion can establish a long-term contract. ${ }^{30}$ In this case, the plaintiff-worker Pugh reported to company higher-ups that his current supervisor was a convicted embezzler, for which the supervisor subsequently fired him. Pugh filed suit, but the trial court dismissed the case at summary judgment. On appeal from the dismissal, the appellate court agreed that Pugh's reporting his supervisor's past conviction was not "whistle-blowing" under the public policy exception, but the long duration of Pugh's good service was sufficient to establish an implied contract. The court therefore reversed and remanded the case for trial. ${ }^{31}$

This example illustrates a concrete case in which an employee is dismissed not because of an objective failing (otherwise one could provide cause for dismissal) but because, essentially, he did not get along with his new supervisor. If the contract were at-will, then dismissal would be immediate. This rule prohibits the dismissal of long-term employees who may not fit in, or, if delinquent in their performance, the employers are unable to provide sufficient evidence of this poor performance.

\subsubsection{Good Faith Exception}

The requirement of good faith and fair dealing is a mandatory rule in contract law, and consequently in employment law. The employment cases involving this exception typically turn on the use of at-will employment by the employer to deprive the employee of compensation. In Mitford v. Lasala, ${ }^{32}$ the discharged employee, who was a party of a profit-sharing agreement with the defendant, was fired to ensure that he would not share profits. The court held that "good faith and fair dealing... would prohibit firing [an employee] for the purpose of preventing him from sharing in future profits."

Currently, courts typically find a rather narrow application of this rule to the timing of dismissal and

\footnotetext{
${ }^{30}$ Pugh v. See's Candies, 171 Cal. Rptr. 917 (Cal. Ct. App. 1981).

${ }^{31}$ At trial, the jury rendered a verdict in favor of the company notwithstanding the appellate court's holding on implied contracts. Pugh v. See's Candies, 250 Cal. Rptr. 195 (Cal. Ct. App. 1988).

${ }^{32} 666$ P.2d 1000 (Alaska 1963).
} 
payment of compensation, rather than to other forms of bad behavior by employers. ${ }^{33}$ Typical examples of wrongful terminations that fit under this class are: 1) a salesman being fired right before his commissions should be paid to him, and 2) an employee being dismissed in order to avoid paying retirement benefits.

As we can see from Figure 1, there are many fewer states adopting this law than in the case of the implied contract rule. Given the more narrow applicability of the rule, this may simply reflect the fact that courts in these states have adhered more closely to the common-law principle of at-will employment, and hence there was a need for statutory intervention to deal with cases where employers avoid paying compensation by a preemptive dismissal. If so, then we might expect this rule to have a substantial impact.

This impact is not due to the effect upon firing costs, but rather because it corrects poorly drafted contracts. In the case of Mitford v. Lasala, the contract was quite clear, and it implied that the firm had no obligation to pay the bonus. Most employees would expect to be paid in such a case, but at the time of writing the agreement they simply would not expect the deception to occur. In such cases, the courts can enhance productive efficiency by essentially completing an incomplete contract.

Consider now the case of Fortune v. National Cash Register Co. ${ }^{34}$ Plaintiff Orville E. Fortune, a former salesman of National Cash Register Company (NCR), brought a suit to recover certain commissions allegedly due from a sale of cash registers to First National Stores. Inc. Fortune had been employed by NCR under a written contract that provided for at-will mutual terminable with notice. The contract also specified that Fortune would receive an annual bonus computed as a percentage of sales that he performed or supervised. In November 1968, Fortune was involved in a supervisory capacity in a sale of 2,008 cash registers to First National, for which the bonus credit was recorded as $\$ 92,079.99$. The next month, Fortune was given notice of termination. NCR ended up keeping Fortune on staff in a demoted capacity and paid him three-fourths of the First National bonus during the summer of 1969. Fortune requested the other 25 percent of the bonus, but his manager told him "to forget about it." Fortune was finally asked to retire in June 1970, and then fired upon his refusal.

At trial, the jury was asked to render two special verdicts: " 1 . Did the Defendant act in bad faith ... when it decided to terminate the Plaintiff's contract as a salesman by letter dated December 2, 1968, delivered on January 6, 1969? 2. Did the Defendant act in bad faith ... when the Defendant let the Plaintiff go on June 5, 1970 ?" The jury answered both questions in the affirmative, and the judge ordered damages of $\$ 45,649.92$. The state supreme court affirmed the judgment.

What is interesting about this case is that NCR did not breach the written terms of the agreement, but the court nevertheless allowed a jury to find that they had acted in bad faith in depriving Fortune of bonuses from the transactions he helped procure. Fortune can be seen as an efficient outcome in that it reduces employee uncertainty about whether they will be rewarded for their efforts and thereby incentivizes optimal investment in the employment relationship.

\footnotetext{
${ }^{33}$ See section 10.2 of Rothstein and Liebman (2003).

${ }^{34} 373$ Mass. 96 (Mass. 1977).
} 


\subsection{Discussion}

The economic model of contract tends to view legal rules as constraints upon individual decision-making, either in terms of increasing transaction costs or imposing constraints upon the wages, hours, and other conditions of employment. In practice, the law is a complex adjudication system that is difficult to describe with an elegant model. Some of the distinctive features of a legal system that are not captured in the economic model of the employment contract include:

1. Contract terms are not self-enforcing. Enforcement is a privately motivated activity that occurs when a plaintiff brings a case before a court. Even rules that have bureaus dedicated to their enforcementsuch as the minimum wage and overtime requirements-rely on information provided by private parties - as well as the volition of agency officials. This demonstrates that enforcement is heterogeneous and a function of employer, employee, and regulator characteristics.

2. When a case is brought to a court, parties cannot rely upon the courts to enforce the agreement as written. Excessive penalties for non-performance are not enforced, for example. Although employment at will is the default rule in the United States, there are several exceptions.

3. Judges do not restrict themselves to contract terms, explicit or otherwise, as relevant legal factors. Courts may collect a large body of evidence regarding the communications and actions of both parties before reaching a decision. Thus, information regarding events not mentioned in the employment contract may nevertheless play a role in adjudicating the dispute.

The fact that courts may overrule contract terms is well-recognized in the legal literature. One of the central issues of this literature is the question of whether or not there is anything we can reasonably call "the law" that allows one to consistently anticipate how courts will rule on a given dispute. There is a related debate regarding how best to think about judicial behavior. ${ }^{35}$

Within economics, there is a small but growing literature that explores the role of the law in ensuring performance. Johnson et al. (2002) find that even if enforcement is imperfect, the existence of courts can help entrepreneurs enter into new supply contracts. Djankov et al. (2003) construct a database consisting of how costly it is to evict a tenant and collect on a bounced check across a large sample of countries, finding that the cost of collection in civil-law countries is significantly higher than in common-law countries. This result is consistent with subsequent work reported in Djankov et al. (2008) for the problem of debt collection. See La Porta et al. (2008) for a more comprehensive discussion of this literature.

For the most part, this work focuses on the costs of the legal system and assumes that variations in these costs across jurisdictions affect economic performance. Botero et al. (2004), and more recently Djankov and Ramalho (2009), explore the extent to which employment law and regulation affect labor market performance. This work uses cross-country variation in measures of employment-law flexibility to identify the effects of the law upon labor-market performance. These papers suggest that the historical origin of

\footnotetext{
${ }^{35}$ See Stephenson (2009) for a nice summary of this debate.
} 
the country's legal regime-whether common-law or civil-law - is often the decisive factor in the evolution of the country's employment rules. However, these papers do not explain this observation. One possible interpretation, perhaps in need of further research, is that laws, like organisms, are adapted not just to the environment but to other laws. The various laws in a legal system-of which employment law is a small part— persist at a steady-state equilibrium unless an overwhelming shock-whether political or economicsuffices to move enough laws to another equilibrium to pull the rest of the legal regime along with them. The rarity of such events-Russia's transition to capitalism is a plausible example-might explain the durable influence of common-law and civil-law institutions on employment laws.

Regardless of this latter conjecture, what is clear from the analysis above is that the law is adaptive, yet existing work does not adequately explain why there is variation in the law. The plausible view taken here is that the law evolves in response to cases brought before the courts. New types of disputes breed new types of law. To understand why these cases arise, we need to understand what exactly is the role of the law in an employment contract. In the next section, we review the literature on the economics of the employment relationship, placing legal rules in the context of the full relationship.

\section{The Economics of the Employment Relationship}

Economic theories of employment begin with a model of human behavior and choice. The standard assumption in economics models of employment is that the worker is a risk-averse individual who wishes to maximize expected utility adjusted for the utility from doing specific tasks and the work environment. ${ }^{36}$ One of the lessons of contract theory is that the optimal contract is often a complex function of the technology of production, the characteristics of the prospective employer and employee, and the information available. In order to highlight the empirical implications of the theory, we begin with a discussion of causality. We then discuss economic models of the employment relationship, highlighting their empirical implications.

\subsection{Why do we need models?}

The purpose of this section is to review the role that economic theory plays in understanding the significance of the law. As discussed in Section 2, even though economic concerns shape the development of the law, economic analysis as developed by the economics profession has played a relatively minor role in explicitly guiding court decisions. ${ }^{37}$ While there may be no explicit accounting of economic effects, it is safe to say that employment rules established by courts have measurable effects on the economy. Accordingly, the goal of the theory discussed here is to structure empirical tests of the impact of employment policy on economic performance.

The recent empirical work in labor economics has been greatly influenced by the potential-outcomes framework, as beautifully exposited by Holland (1986). ${ }^{38}$ I shall briefly review this approach when using

\footnotetext{
${ }^{36}$ See Rebitzer and Taylor (2010) for a discussion of recent research in behavioral economics as applied to labor economics.

${ }^{37}$ For example, see Justice Breyer (2009)'s observation that economics plays a small role in U.S. Supreme Court decision-making.

${ }^{38}$ See also Angrist et al. (1996) and particularly Imbens and Wooldridge (2009) for an up-to-date discussion.
} 
Table 3: Employment Law for a Selected Set of Countries

\begin{tabular}{|c|c|c|c|c|c|c|c|}
\hline Country & Min. Work Age & Holidays & OT Prem. & Sev. Pay & Ret. Ben. Yrs. & Unemp. Wait & Matern. Leave \\
\hline Switzerland & 15 & 9 & 1.25 & 0.0 & 1 & 5 & 4.5 \\
\hline United States & 16 & 0 & 1.5 & 0.0 & 20 & 3 & 1.35 \\
\hline Singapore & 12 & 11 & 1.5 & 12.9 & 5 & n.a. & 3.0 \\
\hline Finland & 16 & 11 & 2.0 & 0.0 & 0 & 7 & 4.2 \\
\hline Italy & 15 & 11 & 1.1 & 0.0 & 19 & 7 & 1.35 \\
\hline New Zealand & 16 & 11 & 1.0 & 0.0 & 0 & 70 & 1.5 \\
\hline Portugal & 16 & 12 & 1.5 & 12.9 & 15 & 0 & 2.0 \\
\hline Uruguay & 15 & 5 & 2.0 & 12.9 & 35 & 0 & 4.1 \\
\hline Malaysia & 14 & 10 & 1.5 & 2.14 & 20 & n.a. & 4.05 \\
\hline Mexico & 14 & 7 & 2.0 & 18.04 & 10 & n.a. & 3.0 \\
\hline Lebanon & 13 & 13 & 1.5 & 12.9 & 20 & n.a. & 3.5 \\
\hline Russia & 16 & 9 & 2.0 & 8.6 & 25 & 0 & 12.0 \\
\hline Lithuania & 14 & 11 & 1.0 & 8.6 & 30 & 8 & 2.0 \\
\hline Jordan & 16 & 12 & 1.25 & 12.9 & 10 & 7 & 2.0 \\
\hline Morocco & 12 & 11 & 1.25 & 0.0 & 9 & n.a. & 3.0 \\
\hline Indonesia & 12 & 12 & 1.5 & 25.8 & 20 & n.a. & 2.25 \\
\hline Zimbabwe & 17 & 11 & 1.0 & 0.0 & 10 & n.a. & 3.0 \\
\hline Armenia & 16 & 13 & 1.5 & 6.45 & 25 & 0 & 6.0 \\
\hline India & 14 & 5 & 2.0 & 6.43 & 10 & n.a. & 4.0 \\
\hline Vietnam & 18 & 5 & 1.5 & 12.9 & 20 & n.a. & 3.0 \\
\hline Madagascar & 14 & 2 & 1.3 & 4.2 & 15 & n.a. & 3.0 \\
\hline Mozambique & 18 & 9 & 1.5 & 25.8 & 10 & n.a. & 0.0 \\
\hline
\end{tabular}

Employment Rules in Sample of OECD Countries. The 85 countries studied in Botero et al. (2004) were ranked by per capita income, and every fourth country was selected. The table presents measurements for the following employment rules. Min. Work Age. The minimum legal age for attaining full-time employment. Holidays. Number of legally mandated paid holidays per year. OT Prem. The premium for working overtime, as a multiple of normaltime wages. Sev. Pay. Legally mandated severance payment for terminated workers, in week's pay. Ret. Ben. Yrs. Years of work required before a worker is eligible for retirement benefits through the country's social security program. Obtained by multiplying the relevant index by 45 (the maximum observation in years) and subtracting that number from 45. Unemp. Wait. Waiting period in days before a worker becomes eligible for unemployment benefits. Obtained by multiplying the relevant index by 70 (the maximum observation in days), and subtracting that number from 70. "n.a." indicates that the country does not offer unemployment benefits. Matern. Leave. Number of months of legally mandated maternity leave. 
economic theory to understand the effects of the law on labor-market performance. First, the framework provides guidance on how to best organize and represent data. Second, it provides guidance on how to estimate a causal effect. Holland emphasizes that it is impossible to establish a causal relationship without some additional hypotheses that themselves can rarely be tested; they must rely on a model of how the world works.

Formally, the model proceeds by supposing that we have a universe of units to be treated, denoted by $u \in U$. For the purposes of our discussion, let $U$ denote all potential workers in the economy. In addition, we might also be interested in outcomes at a state or country level. In that case we let $u^{s} \subset U$ be the subset of individuals living in state $s \in S$, where $s$ could denote a U.S. state among all states or one country among all countries.

This chapter's main concern is labor-market performance, so we restrict our attention to the question of how policy might affect wages and employment. For individual $u$, let $y^{E} \in Y^{E}=\{0,1\}$ be employment status (with 1 meaning employed), and let her wage per period be given by $y^{w} \in Y^{W}=[0, \infty)$. Suppose that these outcomes will be observed in the next period $(t)$. Employment and wages are likely to be affected by employment policies in the next period, denoted by $l_{t}$.

Rubin's model was developed in the context of a medical treatment where one asks if a particular drug has an effect. This question is typically answered by randomly dividing a group of individuals into a treatment and a control group. The causal effect of the drug is measured by comparing the outcomes in the two groups. The problem is that this procedure does not identify the effect of the treatment on a particular individual. In some illnesses, individuals become well in the absence of treatment. For others, the illness may be fatal regardless of the treatment. By chance, it is possible that all the former individuals (the false positives) would be assigned to the treatment group, while the latter individuals (the false negatives) would be assigned to the control group. In that case, the experiment would show that the drug had an effect, even though it did not.

The first issue is how to define a causal effect. In the context of our simple model, let $y\left(u, l^{0}, t\right)$ be the outcome under the status-quo law in the next period, and let $y\left(u, l^{1}, t\right)$ be the outcome under the new rule, say an increase in the minimum wage. Let $\Delta=l^{1}-l^{0}$ denote the policy change. Following Holland (1986), we say that the policy change $\Delta$ at date $t$ causes the effect:

$$
D(u, \Delta, t)=y\left(u, l^{1}, t\right)-y\left(u, l^{0}, t\right) .
$$

This definition is concrete: It is the difference in potential outcomes. In order to measure this "effect," we would have to observe the same outcome for two different policies at the same time, something that is clearly impossible without time travel. Holland (1986) calls the impossibility of observing a causal effect the Fundamental Problem of Causal Inference. His analysis emphasizes the fact that measuring the causal impact of a treatment entails additional hypotheses.

Most solutions to the problem of causal inference rely upon versions of unit homogeneity or time homogeneity. By unit homogeneity we mean that there is a set of units $U^{\prime} \subset U$ with the feature that the effect of 
the change $\Delta$ is the same for all $u \in U^{\prime}$, in which case the effect can be estimated by policy change to unit $u^{1} \in U^{\prime}$ but not to unit $u^{0} \in U^{\prime}$, in which case for $u \in U^{\prime}$ we have:

$$
D(u, \Delta, t)=y\left(u^{1}, l^{1}, t\right)-y\left(u^{0}, l^{0}, t\right)
$$

By time homogeneity, we mean that the effect of the treatment in different periods is the same. Hence, if we can estimate the effect of a treatment on a unit $u$ by comparing the effect over time:

$$
D(u, \Delta, t)=y\left(u, l^{1}, t+1\right)-y\left(u, l^{0}, t\right)
$$

The challenge then becomes finding the homogeneous group. Regression discontinuity is an example of a recent popular technique that provides a way to create homogeneous groups that allow for the estimate of the effect of a treatment. ${ }^{39}$ For example, DiNardo and Lee (2004) argue that firms in closely contested unionization drives are almost identical in most respects. Because the outcomes of union certification votes are very close, one can assume that for these firms union status is randomly assigned. Consequently, we can compare the change in firm value for those firms that were unionized to the change for those that were not, and thereby procure a robust measure of the effects of unionization on a firm's productivity.

Lee and McCrary (2005) provide an example of time homogeneity. Specifically, they look at the effect on behavior of sanctions against crime. Their study exploits the fact that when a person turns 18, they suddenly become eligible to be tried in adult courts, where they will face more severe sanctions than a juvenile court would impose. On the supposition that a person's characteristics just before and after they turn 18 are the same, observed changes in crime-related behavior can be ascribed to changes in criminal sanctions.

Notice that all the work is being done by the assumption of continuity over time with the same union, or across units with very similar characteristics. The great benefit of this approach is that, beyond the continuity assumption (which is a strong assumption), this approach is relatively model-free. The problem is that while it may provide a credible measure of the effect of a policy change, the approach says little if one moves away from the point at which the policy change or treatment is applied.

A formal model in this framework has two distinct goals. The first is that it may provide a concise representation of a set of facts about the world. It describes the set of measured characteristics that one needs to know in order to capture the effect of a treatment. For unit $u \in U$, let $X(u, t) \in \Theta$ be a set of characteristics. In practice, one may not be able to measure all dimensions of $\Theta$, but let us suppose for the moment that we can. Suppose $u$ is a worker and we are interested in explaining worker wages. Then, we would say that a model that specifies a wage $f(X, l, t)$ for a worker with characteristics $X$ is an unbiased representation of the data at date $t$ if for all $u \in U$,

$$
\phi_{u t}=y\left(u, l_{u}, t\right)-f\left(X(u, t), l_{u}, t\right)
$$

\footnotetext{
${ }^{39}$ See Imbens and Lemieux (2008) and Lee and Lemieux (2009) for a discussion of the technique.
} 
is an i.i.d set of random variables with zero mean.

If our model is linear, we can let $\beta(t, l)=\partial f / \partial X$, in which case we can write our model in the familiar regression form:

$$
y_{u t}=\beta\left(t, l_{u t}\right)^{\top} X_{u t}+\phi_{u t}
$$

If our model is unbiased, then this is a well-specified model that can be estimated by ordinary least squares. However, even if the model is well-specified, as Holland (1986) emphasizes, the coefficients of the model cannot be assumed to represent a causal relationship. For example, one of the parameters might be the gender of a worker, say 0 is male and 1 is female. If $y_{u t}$ is the wage, and the coefficient on gender is negative, we cannot say that gender causes a wage drop. This is because gender is not a treatment or something that one normally assumes can be varied within a person.

We can use the coefficient on gender to test various theories. For example, human capital theory predicts that a person's wage is a function only of their productive characteristics, such as schooling, ability, and experience. One reason women might be paid less is that they spend more time out of the labor force in child rearing. This reasoning implies that once the full set of characteristics reflecting productivity is included in $X$, then the coefficient on gender should be zero. If it is not, then we can say there is discrimination in the labor force.

A good theory specifies the set of parameters $X$ that provide all the information necessary to describe wages while preserving time independence:

$$
y_{u t}=\beta\left(l_{u t}\right)^{\top} X_{u t}+\phi_{u t}
$$

Any variation in wages that occurs over time is explained via either changes in the parameters $X_{u t}$ or by changes in the environment $l_{u t}$. In practice, the econometrician may not have access to all the relevant information $X_{u t}$, which leads to the well-known omitted variable bias problem in econometrics. For the present discussion, let us suppose that the relevant data are available and ask how the model can help in measuring the causal impact of a change in law $l$.

In general, economic theories do not provide precise point predictions; more typically, they make predictions about the sign of an effect. In the context of measuring the effect of the law on outcomes, the variation in treatment typically occurs either across jurisdictions-namely, the experiment assumes that all individuals in a particular jurisdiction $u \in U_{s}$ face the same legal environment $l_{s t}$, and it is the legal environment that varies across jurisdictions. For example, many countries can be characterized as civil-law or common-law legal systems. We can let $U_{1}$ be individuals in common-law countries and $U_{0}$ be individuals in civil-law countries, and set $l_{s}=s$.

In the example of civil- and common-law countries, one could estimate $\beta_{s}=\beta\left(l_{s}\right)$ for each jurisdiction. In this case, the causal impact of the legal system depends on the distribution of characteristics of individuals in the economy. We would estimate the causal effect of changing from a civil-law system to a common-law 
system for regions that are currently under civil law in period $t$ by:

$$
\text { Effect of common law }=\frac{1}{n_{0}} \sum_{u \in U_{0}}\left(\beta_{1}-\beta_{0}\right)^{\top} X_{u t} .
$$

In order to estimate the causal effect of a change in the legal system, one needs to use the characteristics of the jurisdiction where the change is to occur. This adjustment is a version of the well-known Oaxaca decomposition, which is widely used in studies of income inequality (see Altonji and Blank (1999)) and union wage differentials. As we discuss in more detail in Section 4, this is not the literature's usual technique. The more common assumption is that the effect of a policy is linearly separable, where for $u \in U_{s}$ we have:

$$
y_{u t}=\beta^{\top} X_{u t}+\beta_{l}^{\top} l_{s}+\phi_{u t} .
$$

Using data for a single period $t$, then, we can estimate the average effect of the legal system on the wages and employment of individuals by:

$$
\beta_{l}=\frac{1}{n_{1}} \sum_{u \in U_{1}}\left(y_{u t}-\beta^{\top} X_{u t}\right)-\frac{1}{n_{0}} \sum_{u \in U_{0}}\left(y_{u t}-\beta^{\top} X_{u t}\right) .
$$

The goal of the theory discussed in this section can be summarized as follows. The theory makes predictions regarding the characteristics $X$ that are needed to represent individual outsources. In particular, it will provide predictions regarding how variations in individual characteristics relate to variations in outcomes. Theory has predictive power if we can safely assume that the relationship between the $X \mathrm{~s}$ and the $y \mathrm{~s}$ is stable over time.

A theory has more predictive power if one can represent outcomes using a smaller set of $X \mathrm{~s}$. Given the difficulty of obtaining good measures of individual characteristics, theories with fewer $X \mathrm{~s}$ are inherently easier to test. On a related note, there is a line of inquiry in statistics that attempts to be model free. This is achieved by supposing that one has a rich set of $X$ variables and that the environment is inherently continuous; as a result, good representations of the data can be used to make predictions on how changes in an individual's $X$ s will affect outcomes. Breiman (2001) suggests that such an approach is sometimes more feasible given present computing resources and the large data sets we have in some domains.

However, representation is not causation. Many individual characteristics are not amenable to experimental treatment. Making causal statements requires that we assume we have a valid representation of the data that allows one to compare outcomes either: 1) across units with similar characteristics but in different treatments, or 2) the same units faced with different treatments over time. In these cases, the theory-in addition to specifying the relevant $X$ variables-also specifies an explicit mechanism by which the law affects the actions of individuals, and hence how one can obtain a valid measure of the causal impact of a change. 


\subsection{Economics of the Employment Contract}

This section discusses the literature that seeks to explain the form and function of employment contracts. Fundamentally, parties who enter into a contract have agreed to have their behavior constrained in the future. The most basic reason for a contract is to support inter-temporal exchange, something that cannot be avoided in the context of labor services. For example, a day laborer agrees to work eight hours in exchange for a wage at the end of the day. When it comes to paying, the employer may have an incentive to renege or attempt to reduce the agreed-upon wage. One role of the law is to enforce such agreements.

In economics, such simple exchanges are typically assumed to be enforceable. The literature has focused on explaining the form of observed contracts that address one of three more subtle issues:

1. Risk. Demand for a worker's services, and hence wages, is likely to change from period to period. Risk-averse workers would like to enter into long-term contracts that would shield them from such shocks.

2. Authority and Asymmetric Information. Decision-making and bargaining are costly under asymmetric information. In this case, contract form can affect performance.

3. Reliance. Once a worker-firm match has been formed, a contract is needed to ensure that each party makes the appropriate investments into the relationship.

What makes the study of employment contracts difficult is that every relationship has elements of these three ingredients. In particular, teasing out the empirical implications of these models has proven difficult. Nonetheless, much of the structure of the legal rules governing employment can be understood as an attempt to address risk, information asymmetries, or hold-up.

\subsubsection{Insurance}

We shall illustrate these ideas using a simple three-period employment model. Suppose that in period 0 the firm offers the worker a long-term employment contract $C$, which the worker can either accept or reject. If the worker does not accept the contract, then in period 1 she will earn $w_{1}^{0}$ and in period 2 she will earn $\omega_{2}^{0}$, which is a random variable with mean $m_{2}^{0}$ and variance $\sigma^{2}$. We will let the realized value of $\omega_{2}^{0}$ be $w_{2}^{0}$. The utility of the worker in this outside market is given by:

$$
U^{0}=u\left(w_{1}^{0}\right)+\delta E\left\{u\left(\omega_{2}^{0}\right)\right\}
$$

The expected lifetime income of the worker is:

$$
W^{0}=w_{1}^{0}+\delta m_{2}^{0}
$$

Given that the worker is risk-averse, a risk-neutral firm who wished to hire this worker for two periods could do so by paying a fixed wage $w^{*}$ per period at an expect cost of $W^{0}-\delta \frac{r}{2} \sigma^{2}$, where $r=$ 
$-u^{\prime \prime}(m) / u^{\prime}(m)$ is the coefficient of absolute risk aversion for the worker. ${ }^{40}$ Let us consider the case in which the owner of the firm is assumed to be able to fully diversify market risk, and hence is able to offer the worker a perfect risk-sharing contract. The firm would be willing to do this because she can offer a wage contract to a risk-averse worker that has a lower expected cost than the worker's market alternative.

Azariadis (1975) introduced the term implicit contract to describe the idea that firms voluntarily smooth workers' income over time in order to lower expected labor costs. Azariadis (1975) and Baily (1974) both observe that the enforceability of these contracts depends upon the existence of turnover costs, otherwise under at-will employment wages would necessarily equal the market alternative. Recently, Blanchard and Tirole (2008) have revisited this issue and suggested that mandated severance pay may enhance the risksharing properties of labor contracts. They explore the question of how to optimally design minimum wages and severance pay to insure risk-averse workers. There is little role for the law in their model beyond enforcing the agreed-upon severance payments.

We consider a two-period extension of their model that will allow for a substantive role for the courts. Rather than supposing that the employment contract is implicit, I follow Blanchard and Tirole (2008) and consider the problem of implementing the optimal allocation. Suppose that in period 0 it is efficient for the worker to contract with a firm with the following profit function:

$$
\Pi=y_{1}-w_{1}+E\left\{\psi_{2}-\omega_{2}\right\},
$$

where $y_{1}$ and $\psi_{2}$ is firm output in periods 1 and 2, while $w_{1}$ and $\omega_{2}$ is the wage paid to the worker in each period. Again, Greek letters refer to random variables.

We begin with a case that entails no enforcement problems, and characterize the empirical implications of the optimal allocation. In this case, we do not have any explicit treatments—rather, we wish to describe the wage and employment profile of the worker (the $y$ 's of the model) in relation to the worker's outside options, the worker's risk preferences, and the firm's productivity in each period (the explanatory $X$ variables of the model).

The optimal allocation is the solution to:

$$
\max _{w_{1}, \omega_{2}, e_{2}} y_{1}-w_{1}+\delta E\left\{e_{2} \psi_{2}-\omega_{2}\right\}
$$

subject to:

$$
u\left(w_{1}^{0}\right)+\delta E\left\{u\left(e_{2} \omega_{2}+\left(1-e_{2}\right) \omega_{2}^{0}\right)\right\} \geq u\left(w_{1}^{0}\right)+\delta E\left\{u\left(\omega_{2}^{0}\right)\right\} .
$$

In addition to wage payment each period, the optimal allocation must also determine the worker's employment status in period 2, where $e_{2}=1$ if employed at the firm and 0 otherwise. If the worker is not employed, the she earns $\omega_{2}^{0}$ in the market, which is assumed to be paid to the worker. The next proposition characterizes the first best:

\footnotetext{
${ }^{40}$ The wage is $w^{*}=\frac{1}{1+\delta}\left(W^{0}-\delta r \sigma^{2} / 2\right)$.
} 
Proposition 1. The optimal risk sharing allocation has the following properties:

1. Employment is ex-post efficient: $e_{2}^{*}=1$ if and only if $\psi_{1} \geq \omega_{2}^{0}$ (and zero otherwise).

2. The worker is fully insured: $w_{1}^{*}=\omega_{2}^{*}=w^{*}$.

3. Expected labor cost is equal to the worker's expected future income less a risk premium that increases with worker's aversion to risk $(r):(1+\delta) w^{*} \simeq W^{0}-\delta \frac{r}{2} \sigma^{2}$.

Observe that this result provides an institution-free description of the optimal allocation that links the characteristics of the optimal contract with potentially observable features of the worker, firm, and labormarket alternatives. In practice, there are a large number of institutions that have been created to insure workers, including workman's compensations, unemployment insurance, transfers within the household, and so on. Rather than delve into the details of these institutions, one may ask the question whether or not institutions are sufficiently rich that something approaching efficient risk-sharing occurs in practice.

Cochrane (1991) works out the implications of the complete risk-sharing model for consumption growth. In our simple model, notice that the wage of a worker (here consumption is assumed equal to wage for simplicity) is independent of whether she works for the current firm or takes up a market alternative (which might mean unemployment). More generally, Cochrane (1991) observes that consumption growth should be independent of idiosyncratic shocks. He finds that full insurance is not rejected for spells of unemployment, loss of work due to strikes, and involuntary moves. However, insurance appears to be incomplete for long illnesses and involuntary job loss. In recent work, von Wachter (2007) finds with German data that the effect of job loss is temporary, with workers returning to their previous earnings in 5 years. Taking a similar approach with data from India, Townsend (1994) rejects the perfect insurance model but does find evidence of significant, albeit imperfect, risk sharing.

This work illustrates the usefulness of the insurance model in organizing consumption data. The work does not test a causal relationship, nor does it describe a mechanism that would generate a relationship between wages and risk attitudes. That mechanism could involve, for example, firms setting wage contracts in advance and workers selecting into contracts that are most appropriate for their risk preferences. Alternatively, firms might negotiate contracts directly with the workers and use worker-specific information, such as marital status, to set the wage contract. In addition, the implicit contract model does not explain wage rigidity per se — and certainly not nominal wage rigidity (see Card and Hyslop (1997))—-only consumption smoothing. If a worker has access to other insurance opportunities, say via their family, then their actions might appear less risk-averse, implying that there may not be a stable relationship between an individual's risk preference and the wage contract.

Consider the question that Blanchard and Tirole (2008) ask, namely: How can one implement the efficient allocation using available legal instruments? The answer to this question can generate some predictions about the effects of changes in the law or in the parameters of social programs such as unemployment insurance. These predictions are causal statements because the choice of law is a treatment; we can ask explicitly what the causal impact of a policy change will be.

Insurance contracts require some form of enforcement when employment with the firm in period 2 is 
efficient. Whenever $\psi_{2}<w^{*}$ the firm would like to dismiss the worker, while the worker would like to quit whenever $\omega_{2}^{0}>w^{*}$. Given that it is always efficient to perform, the parties would never voluntarily renegotiate the contract price. If the contract were between commercial parties for services, termination of the relationship by either party could be followed by a suit for damages. Under the rule of common law the standard remedy is expectation damages - harm caused by the contract breach. Let us suppose that there is a cost $k$ in pursuing a court case. If the employment contract is adjudicated under standard common-law rules, we would have the following outcomes for contract termination ${ }^{41}$ :

\begin{tabular}{|c|c|c|}
\hline State of the World & Breach Decision & Remedy \\
\hline \hline$\psi_{2}<w^{*}-k$ & Firm lays off worker & Worker paid $D=w^{*}-\omega_{2}^{0}$ \\
\hline$\omega_{2}^{0}-k>w^{*}$ & Worker quits & Firm paid $D=\psi_{2}-w^{*}$ \\
\hline
\end{tabular}

Observe that under this rule, if it is efficient for parties to stay together (it is always the case that $\psi_{2}-$ $\omega_{2}^{0}>0$ ), then there would never be breach. For example, suppose that the worker's outside option is so great that it is worthwhile to quit even while paying legal fees, namely $\omega_{2}^{2}-k>w^{*}$. Once she pays the damages to the firm, her income would be:

$$
w^{*}-k-\left(\psi_{2}-\omega_{2}^{0}\right)<w^{*}
$$

Hence, under the standard legal rule of expectation damages, an employment contract that fully insures workers would be enforceable and would implement the efficient contract when turnover is not efficient. In practice, however, these rules are rarely used in employment cases. The common-law rule is employment at will, not expectation damages.

Parties might try to achieve a binding contract by stipulating that each party would pay a large fine $F$ if there is breach. In practice, requiring workers to pay large penalties to leave employment are not enforceable in most legal jurisdictions - this would be akin to a slavery contract. One exception is requiring a worker to pay for training she has received. In the case of professional sports, this goal is achieved by requiring teams to pay a fee to acquire a player. This rule has become controversial, though, and was recently overturned by the European Court of Justice. ${ }^{42}$

The case of sports teams is the exception. For most employment contracts, employees can leave at will. There is literature, beginning with Harris and Holmström (1982), that explores the optimal wage contract under the assumption that the firm cannot fire the worker, but the worker can leave at will. Under such a rule, the optimal contract is downward rigid. It is fixed in real terms and readjusted upwards each time a worker gets an outside offer. Beaudry and DiNardo (1991) suggest that this model can explain why individuals who are hired during recessions are worse off in the long run than workers hired in boom periods. Chiappori

\footnotetext{
${ }^{41}$ I assume that the terms of the wage payment are enforceable, so it is only the decision to quit or layoff that is liable to legal recourse. There is a well-known U.K. case, Rigby v. Ferodo [1988] ICR 29, House of Lords, that establishes the enforceability of the wage payment.

${ }^{42}$ This is the so-called Boseman case. See Feess and Muehlheusser (2002) for a discussion.
} 
et al. (1999) point out, that there may be other reasons for this result, including holdup (which we discuss below).

\subsubsection{Asymmetric Information and The Employment Relationship}

Consider the following extension of Simon (1951) employment model, allowing for task allocation ex post in the presence of asymmetric information. Suppose that in period 2 the worker can be assigned to one of two tasks, $x \in\{a, b\}$, and that the productivity of task $x$ is $\psi_{2}^{x}$, which is assumed to be observed only by the firm. In addition, there is a private cost of carrying out task $x$ to the worker given by $c_{2}^{x}>0$, and which is observed only by the worker. If we let $x=0$ denote the outside option, with $\psi_{2}^{0}=0$ and $c_{2}^{0}=-\omega$, then the respective payoffs to the firm and worker under task $x$ are:

$$
\begin{aligned}
\Pi^{x} & =y_{1}-w_{1}+\delta I_{x}\left\{\psi_{2}^{x}-\omega_{2}^{x}\right\} \\
U^{x} & =u\left(w_{1}\right)+\delta u\left(\omega_{2}^{x}-c_{2}^{x}\right),
\end{aligned}
$$

where $I_{x}=1$ if $x \in\{a, b\}$ and 0 otherwise.

Note that regardless of the contract, the optimal task allocation is given by:

$$
x^{*}\left(\theta_{2}\right)=\arg \max _{x \in\{0, a, b\}}\left\{\omega_{2}^{0}, \psi_{2}^{a}-c_{2}^{a}, \psi_{2}^{b}-c_{2}^{b}\right\} .
$$

Let us first suppose that it is efficient for the worker and the firm to stay together both periods. Also suppose that there is no variation in task productivity, but that the worker's cost, $c_{2}^{x}$, can vary. In this case, the efficient solution is to allocate the choice of task to the worker, who will always choose the efficient allocation. More generally, as Milgrom (1988) argues, this effect leads to an organizational structure that limits the authority of the firm, so that within certain task groups individuals are given autonomy.

Given that the worker is risk-averse, the optimal solution entails a fixed wage and an allocation of decision rights to the worker. If $w^{*}>\psi_{2}^{a}, \psi_{2}^{b}>\omega_{2}^{0}+c_{2}^{a, b}$, it is efficient for the worker to stay matched with the firm, but the firm would prefer to lay the worker off rather than pay wage $w^{*}$. Enforcing the efficient contract requires a stipulated severance pay that is sufficiently large but conditional upon worker's performance. Similarly, the efficient contract should ensure that the worker does not threaten to renegotiate the wage contract in period 2 . These points are summarized in the following proposition:

Proposition 2. If the firm is indifferent over task assignment $\left(\psi_{2}^{a}=\psi_{2}^{b}\right)$, then the optimal contract has the following conditions:

1. The worker has the right to choose her preferred task.

2. The contract wage each period is decreasing with the worker's risk aversion, increasing with minimum cost of effort and expected lifetime market income $\left(w_{1}^{*}=w_{2}^{*}-\min \left\{c_{2}^{a}, c_{2}^{b}\right\} \simeq\left(W^{0}-\delta \frac{r}{2} \sigma^{2}-\right.\right.$ $\left.\left.\delta \min \left\{c_{2}^{a}, c_{2}^{b}\right\}\right) /(1+\delta)\right)$.

3. If the worker leaves in period 2 , then she pays a penalty $P>\omega_{2}^{0}-w_{2}^{*}+c$. If the firm dismisses the 
worker, it pays $f>\max \left\{\psi_{2}^{a}, \psi_{2}^{b}\right\}-w_{2}^{*}$ in severance.

This contract is very much like the contract for a tenured academic. The contract asks the professor to carry out teaching duties but typically allows a great deal of discretion over how she teaches and the material she will use. Second, the demand for the services of an academic is stable, and hence there is little benefit from turnover. As a consequence, the academic cannot be fired. The optimal contract also precludes the worker from leaving without paying a penalty, but this sort of provision is not typically observed (aside from the sports contracts mentioned earlier). For academics, the resignation penalty is implicit, consisting in large moving costs, lowering the incentives to leave. Note that a consequence of removing the penalty clause for leaving is that the period 2 wage would be more responsive to the outside market, and as a consequence the first-period wage would fall. Conversely, sometimes it is suggested that tenure be abolished. The consequence of abolition would be to lower expected income in period 2, which in turn would raise period 1 wages.

In terms of empirical predictions, this result merely links $X$ variables - the risk aversion of the worker and job characteristics - to predicted contract choice. Hence, this proposition does not make any causal claims, but predicts that there should be an association between measured risk aversion of the worker, job characteristics, and turnover. It predicts that certain jobs, such as academic jobs, combine substantial job protection with the freedom to control activities on the job.

In order to introduce a notion of just cause for dismissal, there needs to be a substantive role for the firm in task allocation. The next case supposes that effort costs do not vary with the task, $c_{2}=c_{2}^{a}=c_{2}^{b}$, but the productivity of the tasks vary, $\psi_{2}^{a} \neq \psi_{2}^{b}$. Let us continue to suppose that it is always efficient to be employed at the same firm for two periods. In this case, it is efficient to provide the worker with a fixed wage contract, $w_{1}^{*}=w_{2}^{*}-c_{2}$. It is crucial that the worker and firm not negotiate the task allocation. If the wage paid for each task is the same, and the firm has the right to make the task allocation $x \in\{a, b\}$, then it will choose the most productive task. Hence, this contract is incentive-compatible in the sense that the firm will make the most efficient choice even though she holds private information. In order to provide the firm with authority over the worker, there must be a penalty associated with not following the firm's instructions. More formally, we have:

Proposition 3. Suppose that employment with the firm is always efficient. Then the optimal contract consists of a fixed wage each period along with the following conditions:

1. The contract wage each period is decreasing with her risk aversion and increasing with cost of effort $\left(w_{1}^{*}=w_{2}^{*}-c_{2} \simeq\left(W^{0}-\delta \frac{r}{2} \sigma^{2}-\delta c_{2}\right) /(1+\delta)\right)$.

2. Should the firm dismiss the worker without cause, the worker is paid $f>\max \left\{\psi_{2}^{a}, \psi_{2}^{b}\right\}-w_{2}^{*}$ in severance.

3. If the worker is indifferent over task assignment $\left(c_{2}=c_{2}^{a}=c_{2}^{b}\right)$, then she agrees to carry out the task assigned by the firm; otherwise she is dismissed and pays a penalty.

This proposition describes the features of an optimal contract when the worker is risk-averse and separation is not efficient. It is useful because it captures some features of observed default rules in employment 
law. Notice that the firm has authority because it has the information regarding the best task to carry out. More generally, Aghion and Tirole (1997) have shown that authority should be allocated to the best-informed individual. ${ }^{43}$ Dessein (2002) extends this point to look at the trade-off between communication and delegation, finding that delegation can be more efficient than communication when there is little conflict between the preferences of the worker and firm.

The provision of insurance via wages does create potential conflict. The firm must have the right to penalize workers who do not carry out their assigned tasks. But this power cannot be unchecked. For example, the firm might try to renege upon the wage contract by assigning a worker very unpleasant tasksformally, those with a high cost of effort $c_{2}$-that would effectively cause the worker to quit. Such a case might lead to litigation where the worker would claim constructive dismissal. ${ }^{44}$ Hence, in practice, such a contract may still face significant litigation.

The results above suggest that if labor contracts are incomplete, with parties relying upon the courts to set the default terms, then both propositions predict that a change from at-will to just-cause dismissal will lead to lower wages and higher employment. Higher employment occurs because just-cause dismissal is more efficient in these cases, and hence should increase employment. ${ }^{45}$ Wages are lower because the worker faces less risk.

Note that the employment result does not fundamentally depend on worker's risk aversion. The employment law we have discussed builds upon contract law, where the key issue is ensuring that parties deliver the promised quality. Disputes arise when firms feel that workers have not performed as promised, or workers believe they have performed as promised but the firm has not compensated or continued employment as promised. This set of issues is legally distinct from the body of law that has developed to enforce insurance contracts, and accordingly the doctrines regarding damages in employment law rarely entail an explicit discussion of risk.

Finally, there is literature, beginning with Shapiro and Stiglitz (1984), that views the right of dismissal as a necessary ingredient for effort provision. In their model, the firm offers a high wage and threatens to dismiss the worker should she shirk. In this model, this results in an inefficient allocation due to the high wages offered by the firm. However, as MacLeod and Malcomson (1989) show, the threat of firing is not necessary for effort provision. The firm can use bonus pay, in which cost enforcement depends upon the firm facing a cost should it renege upon a promised payment. MacLeod (2003) extends this result to the case of a risk-averse worker employed with an imperfect performance measure. ${ }^{46}$ He shows that a necessary condition for the implementation of an efficient contract is the ability to impose a cost upon firms that renege on bonus pay. The good-faith exception to employment at will is one mechanism that may achieve this condition.

\footnotetext{
${ }^{43}$ See also Chakravarty and MacLeod (2009), who discuss the allocation of authority in the context of contract law. They show that construction contracts carefully allocate authority between the buyer and seller to ensure efficient production.

${ }^{44}$ This is a legal term of art in English law defined by the U.K. Employment Rights Act of 1996, § 95(1)(c). Even if an employee resigned from her post, she can claim that she was forced to quit due to the employer's action.

${ }^{45}$ See MacLeod (2005) and MacLeod and Nakavachara (2007) for more details on how employment law may enhance efficiency.

${ }^{46}$ See Levin (2003) and ? for a more detailed analysis of the risk-neutral case in a repeated-game setting.
} 


\subsubsection{The Reliance Interest}

In a famous paper, Fuller and Perdue (1936) introduced a conceptual framework that has formed the basis of the modern law-and-economics treatment of contract law. The goal of their paper was to provide a framework for the setting of damages for contract breach. They introduced three ways to measure damages. The first of these, as discussed earlier, is expectation damages. This is the rule that one would use if one wished to enforce an insurance contract because it ensures that each party obtains the desired outcome while ensuring that matching is efficient.

The notion of expectations is not always well defined, particularly in the case where the value of the worker's performance is private information. Another way of measuring damages is the notion of restitution. This damages rule strives to restore the harmed party to the state she was in before the contract was agreed upon. For example, suppose a worker sells her house and moves to a new city in order to take up employment. If the potential employer reneges on the contract, restitution damages would entail paying the harmed worker the costs of relocation so that she may return to her previous state.

A third measure of damages is the reliance interest. Take, for example, an employer that spends a significant amount of money training a worker, as in the military providing pilot training. In that case, if the worker were to leave employment early, the employer may ask the worker to repay part of the training expenses.

The early literature on the economics of contract law, notably Rogerson (1984) and Shavell (1984), consider the case in which parties make a sunk investment into a relationship, and then ask, which of this damage rules leads to the most efficient level of investment. This work illustrates an important third motivation for an employment contract: namely, to provide incentives for efficient relationship-specific investments. The early literature assumed that the investment was observable by the courts, and hence could be used to set damages. In an influential paper, Grout (1984) showed that if parties could not write a binding contract, then there would be inefficient investment into the relationship. This model has become the paradigm for the holdup problem, a term coined by Victor Goldberg (1976) to describe situations in which the buyer or seller attempts to change the terms of an agreement after have there been significant sunk investments. Williamson et al. (1975) similarly make the point that relationship-specific investments imply that the employment relationship must be carefully governed to avoid opportunistic behavior by the worker.

These points can be formally illustrated in our model by supposing that the employer makes an investment into capital $k$ in period 1, while the risk-neutral worker makes a similar investment $i$. In this case, the worker's investment can be any activity that lowers the cost of supplying labor, which might include making friends, investing in a new home, or acquiring skills on the job. Formally, the payoffs of the firm and the worker would be:

$$
\begin{aligned}
\Pi & =y_{1}-w_{1}-k+\delta E\left\{e_{2}\left(\psi_{2}+y(k)\right)-\omega_{2}\right\} \\
U & \left.=w_{1}-i+\delta E\left\{\omega_{2}+e_{2} v(i)+\left(1-e_{2}\right) \omega_{2}^{0}\right)\right\}
\end{aligned}
$$


where the notation is as above, except now worker productivity depends on investment $k$ via $y(k)$, and worker utility depends upon her investment $i$ via the $v(i)$. It is assumed that $y(0)=v(0)=0, y^{\prime}, v^{\prime}>0$, and $y^{\prime \prime}, v^{\prime \prime}<0$, and that the efficient levels of investment are characterized by:

$$
v^{\prime}\left(i^{*}\right)=y^{\prime}\left(k^{*}\right)=1 / \delta \rho_{2}^{*}
$$

where $\rho_{2}^{*}$ is the probability that the worker and firm trade in period 2 under efficient matching (namely $\left.\rho_{2}^{*}=\operatorname{Pr}\left[\psi_{2} \geq \omega_{2}^{0}\right]\right)$.

Observe that the level of investment into a relationship depends upon both the discount rate and the expectation that the relationship will continue. This implies that if a worker, for example, overestimates the likelihood that an employment relationship will continue in period 2, this can lead to over-investment, and an increased incentive to litigate discharge should she believe it to be unjustified.

The holdup problem arises when the worker and firm have no binding labor contract but instead negotiate the wage in period 2 after the value of their outside options have been realized. Grout (1984) supposes that period 2 wage is given by the Nash bargaining solution, which entails parties dividing evenly the gains from trade to yield a wage:

$$
w_{2}\left(\psi_{2}, \omega_{2}, k, i\right)=\left(\psi_{2}+y(k)-v(i)-\omega_{2}^{0}\right) / 2 .
$$

When this wage is negative, parties will choose the outside option rather than trade. This rule ensures efficient matching in period 2, but the returns from the specific investments are divided equally between the worker and the firm. In consequence, we have underinvestment:

Proposition 4. In the absence of a binding employment contract, the worker and the firm choose investments to satisfy:

$$
y^{\prime}\left(k^{n c}\right)=v^{\prime}\left(i^{n c}\right)=1 / \delta \rho_{2}^{n c},
$$

where the probability of employment in period $2, \rho_{2}^{n c}<\rho_{2}^{*}$, is less than the efficient level, and hence investments are less than the first best $\left(k^{n c}<k^{*}\right.$ and $\left.i^{n c}<i^{*}\right)$.

The motivation for Grout's model is the legal rule in the United Kingdom that makes it impossible for unions to enter into binding contracts with employers. The substance of the Trade Disputes Act of 1906 made it impossible for employers to sue unions, and hence to recover damages should a union strike.

To predict the causal impact of such a policy, one needs to work out what would happen if contracts were enforceable. The holdup model supposes that investments are observable by the two parties but cannot be used to set contract terms. Under this assumption, Hart and Moore (1988) show that parties would agree to a contract with a stipulated wage $w_{2}$ and severance payment $s_{2}$ that would improve upon no contract. In general, however, the contract will not implement the first best. This can only occur in this model if it is always efficient to trade, and there is a contract that, with probability 1 :

$$
\psi_{2}+y\left(k^{*}\right)-w_{2} \geq-s_{2}
$$




$$
w_{2}+v\left(i^{*}\right) \geq \omega_{2}^{0}+s_{2} .
$$

For this contract to work, one does need legal enforcement. If either the worker or the firm attempts to modify the contract terms, the other party should be able to seek relief in court. This is not to say that parties cannot, if they wish, renegotiate the contract by mutual consent. Given that both parties are better off under the contract than on the outside market, however, the threat not to trade is not credible. Hence, the wage would not be renegotiated in period 2, and both parties receive the full return from any specific investment.

Hart and Moore (1988)'s result that contracts can always improve matters holds only for the case of specific self-investments: the investments that affect one's own payoff but not the other party's payoff. Che and Hausch (1999) show that in the case of cooperative investments-that is, when one party's investments affect the payoffs of both parties - and when contract renegotiation cannot be precluded, then there is no benefit from writing any contract. This result depends on the hypothesis that the courts cannot observe the investments. Given the level of litigation in employment, one must conclude that parties do indeed find it useful to write contracts. The issue is how the courts should enforce these contracts.

An interesting feature of the holdup model is that the efficiency of the relationship can be enhanced in some cases with the appropriate allocation of bargaining power. This idea begins with the so-called property-rights approach of Grossman and Hart (1986). They observe that even though contract may not be explicitly conditioned upon certain events, the law can allocate residual decision rights. The example they explore in detail is property, which in effect is a contract that gives the owner of property the right to carry out any action that is not constrained by other contracts.

We have a similar issue in employment law. That is, under what conditions does the worker or the firm have the right to leave a relationship based on information that may not be observable by the courts? Aghion et al. (1994) show that if one can design contracts to allocate the bargaining power of parties, then one can achieve an efficient allocation in the models of Gout (1984) and Hart and Moore (1988). ${ }^{47}$

These are useful abstract results that delineate conditions under which efficient allocations can be achieved, but they do not specify the legal institutions that would achieve these allocations. MacLeod and Malcomson (1993) explicitly explore the implications of the holdup model on wages over time when the market alternatives are viewed as an outside option in the sense of Shaked and Sutton (1984). The outside option principle has two parts.

First, if at the current, enforceable wage both parties are better off than at their next best alternative, then threats to leave/layoff are not credible and hence the wage is insensitive to current market conditions. As Howitt (2002) observes, this observation has the potential to provide a theory of rigid wages. Second, when the current wage is worse than, say, the worker's best alternative, then either the wage will be renegotiated to be equal to this alternative, or the worker will leave.

Given these rules, MacLeod and Malcomson (1993) show the following:

1. When investments are general and there is a fixed cost to changing jobs or employees, then a fixed

\footnotetext{
${ }^{47}$ These results build upon the implementation results of Moore and Repullo (1988).
} 
wage contract that is renegotiated to match outside offers implements the first best.

2. In the case of two-sided self-investments, if it is possible to index wages so that the outside options are binding only when separation is efficient, then such an indexed wage contract implements the first best.

3. In the case of cooperative relationship-specific investments by the firm, an efficient allocation is implemented with a contract that leaves the worker indifferent between employment and taking up the outside option. Conversely, if the worker is making the investment, then the efficient rule leaves the firm indifferent between hiring the worker and taking up the outside option.

These three cases are not comprehensive, however. For example, Rogerson (1992) shows in a more general, asymmetric-information setup that there is a wide variety of situations where there exist efficient contracts when both parties are risk-neutral. The holdup model is attractive because it provides some predictions on contract form when parties approximately satisfy these contracts.

What is particularly interesting about these results is that they are broadly consistent with the doctrine of employment at will. The first case merely requires that the worker and the firm agree to some wage contract that can be periodically renegotiated. In particular, the wage can be in real or nominal terms, and hence, as Howitt (2002) points out, can explain nominal wage rigidity. Though the model also predicts that nominal wages may be renegotiated up or down by arbitrary amounts, depending upon the outside market, a behavior that is consistent with the evidence of Blinder and Choi (1990), McLaughlin (1994), and Card and Hyslop (1997), but not consistent either with menu-cost models or the model with risk-averse agents.

These models do rely upon the legal enforcement of a contract wage that cannot be unilaterally changed by one party, a principle that was affirmed in the United Kingdom by Rigby v. Ferodo (1987). ${ }^{48}$ We also observe the use of indexed contracts, particularly union contracts: Cousineau et al. (1983) document the use of indexed contracts by Canadian unions. Notice that the risk-sharing model would predict fixed real wages, with corresponding penalty clauses to enforce the risk-sharing agreement. The fact that penalty clauses are typically not enforceable, especially in the case of employment contracts, leads to the prediction that if parties are going to index, then the indexed contract should approximately follow the market wage, which is what we observe in Canada (and also in the case of long-term supply contracts, as documented by Joskow (1988)).

Crawford (1988) shows that the holdup problem can also be solved when parties sign a series of shortterm contracts. Essentially, parties anticipate their future holdup and mitigate its effect by agreeing in the current period to lower wages combined with higher investment. Card et al. (2010) find some evidence in support of this prediction using Italian data. Given that these are unionized firms, this suggests that the firms are able to reach efficient bargains.

The final case is implemented in the absence of any contract, and can help explain the puzzling fact that contracts do not consistently have index terms. As Cousineau et al. (1983) have shown, about 50\% of

\footnotetext{
${ }^{48}$ [1988] ICR 29, [1987] IRLR 516.
} 
unionized firms in Canada did not index their employment contracts during a period of high inflation. This would imply that unions would have to constantly renegotiate their contracts to match market conditions. Result 3 implies that this contract form provides first-best incentives for the firm to invest in capital and into relationship-specific worker training. Acemoglu and Pischke (1998) also show that if there are significant turnover costs, then firms may also invest into general human capital.

\subsection{Implementing the Efficient Employment Contract in a Market}

The literature on the employment contract has identified three broad economic motivations for an employment contract: insuring risk-averse employees, ensuring the revelation of relevant information for decisionmaking, and encouraging relationship-specific investments. Given these transaction costs, the next issue is: What sort of labor-market institutions ensure efficient matching and trade?

In principle, one could construct a model that includes all the ingredients that have been identified as relevant for understanding employment. At a purely abstract level, Rogerson (1992) and Aghion et al. (1994) have shown that under the appropriate conditions, one can construct an abstract mechanism that implements the efficient allocation in a variety of cases, some of which combine risk aversion and asymmetric information. However, as Tirole (1999) discusses, we still do not know how to relate these abstract results to observed institutions and contract forms. The literature on employment typically explores the implications of regulation for a simple model that has one or at most two transaction costs. The literature on employment protection has for the most part followed the lead of Bentolila and Bertola (1990) and Lazear (1990) in supposing that an increase in labor protection is parsimoniously modeled as an increase in turnover costs.

Lazear (1990) observes that if complete contracts are possible, mandated severance payments can always be undone via the labor contract. In that case, a law mandating severance payments would have no effect on employment but would lower starting wages. Lazear carries out a study of 22 countries over a 29 -year period and concludes that increasing severance pay to 3 months' salary for workers with 10 years' experience leads to a 1-percent reduction of the employment-to-population ratio. This is a reduced-form analysis that does not take into account the complex inter-temporal optimization problem faced by firms. This is the goal of Bentolila and Bertola (1990). They find that firing costs create complex inter-temporal incentives that depend upon the state of the business cycle. Specifically, firing costs reduce labor demand in good times but increase demand in bad times. Lower starting wages translate into lower firing costs, and hence firms have greater incentives to hire workers during downturns.

The literature has mostly followed the lead of this work and modeled employment protection as a turnover cost. The theoretical contributions have begun with one of the transaction costs (risk, asymmetric information, or holdup) and then explored the implications of employment protection modeled as a turnover cost. This allows one to explore the implications of treating a relationship with a particular policy choice. If we suppose that in different relationships one of the three transaction costs is more important, then this approach generates testable predictions of the effect of a law change for different relationships, which hopefully can be measured and hence form right-hand-side $X$ variables. 
I complete the section with a brief discussion of unions. From the perspective of transaction costs, one can view unions as an alternative to employment law. This provides a system for the implementation, enforcement, and arbitration of employment disputes between the firm and unionized employees.

\section{Risk}

Since the work of Azariadis (1975) and Baily (1974), the assumption of risk-averse workers has played an important role in the development of labor policy. I showed above that if the main role of the labor contract is to insure workers, then such a contract can be enforced with the use of expectation damages. Moreover, the contract will have the feature that if a relationship is no longer efficient, then the firm has the obligation to "sell" the worker's contract to another firm. In the absence of bankruptcy constraints and asymmetric information, such an institution would implement the first best. ${ }^{49}$

In practice, we observe contracts with features similar to this in the area of sports, but rarely elsewhere. In the case of athletes, the quality of the player and hence the value of a trade is information that is easily available to the teams in a league. Such conditions are not likely to be satisfied in general, however. There is an active literature in macro-economics that explores the role of turnover taxes and mandated severance pay when complete contracts are not possible. A seminal contribution in this literature is Hopenhayn and Rogerson (1993). They assume that workers have access to complete financial markets and hence can diversify firm risk. Under these assumptions they show that a turnover tax (or severance pay) is equal to one year of wages leads to a $2.5 \%$ reduction in employment.

Their model assumes away market incompleteness. Hopenhayn and Nicolini (1997) consider the case in which the firm provides the insurance services for the worker, but the worker is responsible for finding a new job. The point is that the matching process is both costly, and is an important element in labor market performance. They show that there should be a mandated unemployment insurance that is financed out of a re-employment tax. Moreover, the level of insurance (or replacement rate, that is, the fraction of one's wages that are paid when unemployed) should fall with time. They show that this rule can result in a significant increase in market performance. The result also illustrates one role for government intervention that arises when there is a combination of risk aversion and moral hazard (worker's search effort is not observed).

Notice that in the presence of fixed unemployment insurance payments, mandated severance pay provides an approximation to such a rule because it provides a high income to the worker early in her unemployment that is lost once the severance pay is spent. In the event of an employment dispute, even if the worker wins the case, in most jurisdictions there is a mandatory rule that parties should mitigate their losses from contract breach. In the case of an employee, this means that the employee should make a reasonable effort to find alternative employment. Any damages due to the worker would be based upon lost income given the new job.

Acemoglu and Shimer (1999) introduce a careful model of the matching process that generalizes many of the previous matching process, and then derive the optimal unemployment insurance. If the agent is

\footnotetext{
${ }^{49}$ See Dye (1985), who uses this point to build a theory of contract length.
} 
risk-neutral, then there should be no unemployment insurance. This is equivalent to saying that employment at will is efficient when workers are risk-neutral. However, when workers are risk-averse, the provision of unemployment insurance increases wages, employment, and the capital-labor ratio. Pissarides (2001) explicitly discusses the role of employment protection. He also shows that with search frictions it is optimal to have unemployment insurance, and observes that employment legislation is an (imperfect) substitute for employment protection.

Finally, the recent paper Blanchard and Tirole (2008) builds upon these themes to explore the implementation of an efficient severance pay-unemployment insurance system in the face of a variety of market imperfections. There are cases in which there are limits on insurance and layoff taxes, ex post wage bargaining, and ex ante heterogeneity of firms or workers. The key insight is that not only do these various cases affect the design of insurance system, but that a third party such as the government is needed in order to implement the second-best optimum. In particular, if the state merely provided a set of courts that enforce private agreements, this would not achieve the first best.

This body of work is carried out using relatively conventional assumptions regarding the operation of the labor market. Together they suggest that arguments by legal scholars—such as Epstein (1984) or Morriss (1995-1996) - that the efficiency of free markets implies that there is no role for government intervention into labor markets are not correct as rhetorical statements. However, there are many issues that this literature does not address.

First, these results depend upon workers having stable risk-averse preferences. There is a large body of work that finds that the fine-grained predictions from a model with risk-averse preferences are not consistent with the data. See Rosen (1985) and Hart and Holmström (1987) for important early evaluations of the literature. More recently, Gibbons (1997) has argued that the standard agency model does not adequately explain many features of observed contracts.

Some recent exciting research on the preferences of individuals may provide a way forward. Andreoni and Sprenger (2010a) show that previous research measuring risk and time preferences do not adequately control for the risk inherent in future rewards. In a follow-up paper, Andreoni and Sprenger (2010b) explicitly measure risk and time preferences. They find that individuals cognitively view choices as risky or not, but among risky choices they have relatively flat attitudes toward risk. This is consistent with the fact that individuals want to avoid risk but that there is no stable empirical relationship between attitudes toward risk and the form of the optimal contract. This research is very new, and this latter point is yet a conjecture. If these results hold, they may allow for much better models of contract and optimal unemployment insurance.

\section{Asymmetric Information}

Asymmetric information is ubiquitous in the employment relationship, which leads naturally to the question of how employment law and other labor market-institutions should be designed to handle this problem. Section 3.2.2 provided some examples of situations where asymmetric information can help explain both contract form and the allocation of authority within a relationship. The difficulty is how best to mediate the 
information problems that arise both within the relationship and between different potential matches.

The early literature focuses on the question of how contracts should be designed to ensure optimal matching when the firm has private information on worker productivity and the worker has private information on alternative opportunities. In a classic paper, Diamond and Maskin (1979) compare expectation damages (they call them compensatory damages) to privately negotiated liquidated damages in a buyer-search model. When parties match, they obtain a gain from trade that is split evenly. The issue is how much they should pay should they find a better match — this will affect the incentives to search and whether or not separations are efficient. They find whether or not one damage rule is better than another depends upon the technology of search; hence, in general, it illustrates that in a world with costly search it is difficult to obtain a clear general prediction on the optimal default rule.

In the employment context, workers are rarely asked to pay for damages should they find a better match. Hall and Lazear (1984) begins with this observation and compares three contract forms:

1. Fixed wage $w$ is set in advance. Trade occurs only if both parties prefer trade to no trade at this price. This contract leads to inefficient quits and layoffs.

2. Firm sets wage knowing worker's productivity. This is essentially the monopsony solution: The firm has an incentive to set wages above the marginal product of labor, so there are inefficient separations whenever the worker's outside option is between the wage and the worker's marginal product.

3. Workers set wages (monopoly union model). In this case, the worker sets his wage above his outside option, resulting in the firm inefficiently not employing worker when marginal product of worker is greater than his outside option, but below wage demanded.

If information is symmetric, then in case 1 we should observe renegotiation and efficient trade. However, as Myerson and Satterthwaite (1983) have shown in a general mechanism-design framework, when there is two-sided asymmetric information, efficient trade is impossible. Hence, as Hall and Lazear (1984) observe, there is no simple contract that implements efficient trade ex post. Even in the absence of risk aversion or relation-specific investments, there are limits to efficient trade that no legal rule or contract can overcome.

There are, however, situations under which efficient trade is possible. If a worker's outside option is known, then giving the firm all the bargaining power results in efficient separations, just as it resulted in efficient task assignment in section 3.2. This is a reasonable assumption when the labor market is thick, as would be the case for, say, casual day labor. In that case, at-will employment is an efficient rule. If variations in outside options are due to variations in worker's ability, then efficiency can still be achieved with the use of piece-rate contracts, as Kanemoto and MacLeod (1992) show. Such a result is consistent with the good-faith exception to employment at will that requires firms to follow through upon promised performance pay.

If it is possible to measure firm productivity, then the efficient rule is to give the worker all the bargaining power. In that case, the worker would offer a wage contract that would make the firm indifferent between acceptance and rejection, with the result that trade would occur if and only if it is efficient. Gibbons (1987), 
in a paper that complements Kanemoto and MacLeod (1992), shows that if the firm has bargaining power and the workers have information regarding the difficulty of the job, then the resulting contract is inefficient. If the workers were given all the bargaining power in this case, then the first best would be restored.

Though this point follows naturally from the question of how to implement efficient exchange under asymmetric information, it is oddly missing from the literature on unions. Freeman and Medoff (1984) made the point that unions can enhance efficiency via the "voice" mechanism, which can be interpreted as solving the problem of asymmetric information. Beginning with McDonald and Solow (1981), there is a literature that wonders why unions cannot bargain over both wages and employment to achieve an efficient outcome.

One reason is that, in practice, we are typically in a situation with two-sided asymmetric information. In that case, one cannot in general achieve the first best. However, if there are choices whose marginal costs vary with the hidden information, then optimal contracts should incorporate this information. This observation has lead several contributions that explain observed contracts as a solution to this problem. The early work of Grossman and Hart (1981) shows that employment-wage policies of a firm are designed to reveal underlying productivity, which can result in observed wages that are different from the true marginal product of labor. Moore (1985) has refined this analysis, to show that when there is two-sided asymmetric information with risk-averse workers, the extent to which the optimal employment contract exhibits over- or under-employment depends upon the preferences of the workers, as well as the nature of uncertainty.

Aghion and Hermalin (1990) introduce a contracting model with asymmetric information and signaling. They show that laws mandating employer-provided benefits can enhance efficiency. There are also papers illustrating that several features of union contracts can be viewed as solving an information problem. Kuhn and Robert (1989) show that seniority rules are a form of efficient price discrimination against the firm. Laing (1994) provides a more general analysis of employment contracts with asymmetrically informed agents, finding that a seniority layoff rule may improve efficiency. Levine (1991) suggests that requiring just cause for dismissal risks attracting low-quality workers. Hence, it is argued that mandated just cause rules may enhance efficiency. Kuhn (1992) observes that requiring mandatory notice of plant closings enhances labor-market performance by ensuring that the firms inform workers in a timely fashion and allow them to make more efficient separation decisions.

There is a recent literature that takes a reduced-form approach to employment protection based on the idea that employment protection acts as a turnover tax that interacts with asymmetric information. Kugler (2004b) observes that in the presence of turnover costs, firms favor more skilled employees, and hence try to fill vacancies from currently employed workers. Hence, she finds that increases in employment protection reduces the flow from unemployment. Pries and Rogerson (2005) introduce more structure to the process regarding worker quality. They suppose that the formation of a match is both an inspection and experience good. The former requires firms and workers to engage in explicit search to form matches, while the latter implies that the signal of match quality becomes more precise with tenure. They explore several labormarket policies, including unemployment insurance, a minimum wage, and dismissal costs. They find that 
dismissal costs lead to higher unemployment, lower turnover, and higher-quality matches. In contrast, Burguet and Caminal (2008) show that if there is contract renegotiation and uncertainty regarding match, then turnover costs can enhance market performance. Guerrieri (2008) introduces a dynamic general equilibrium model with asymmetric information regarding match quality. She shows that in a dynamic economy the first best cannot be achieved with out government intervention in the form of a lump sum tax upon all workers. Finally, Matouschek et al. (2009) formally consider the implications of contract renegotiation when there is asymmetric information regarding outside options.

The extent to which asymmetric information might "explain" observed contracts, and justify the existence of unions or additional taxation depends upon the magnitude of the asymmetric information. Using evidence from layoffs, Gibbons and Katz (1991) find that workers who lose jobs from a plant closing have higher subsequent wages than those who are laid off. This is consistent with later work by Gibbons et al. (2005), where high-skilled workers earn greater returns to their skill. This evidence supports the hypothesis that labor market wages are a first-best approximation for worker ability. If it is true, then this would suggest that ex post efficiency is best achieved with as little market intervention as possible.

This policy choice is no longer ideal if the labor contract must also ensure ex ante efficient investment. We turn to this issue next.

\section{Holdup}

When worker's productivity is common knowledge, but the cost of labor supply is private to the worker, then it is optimal to allocate all ex post bargaining power to the worker. However, this is not in general ex ante efficient. When unions and firms are in a long-term relationship, the firm will make investment decisions a function of their expected return from these investments. Grout (1984) has shown that if the union (or worker) has ex post bargaining power during contract renegotiation, then there is underinvestment.

Becker (1962), Mincer (1962), and Williamson et al. (1975) have emphasized that the employment relationship typically entails relationship-specific investments. This raises two issues. First, can the employment relationship be governed in such a way that one has efficient investment combined with efficient matching? Second, what are the implications for wages over time? Hashimoto (1981) introduces a model of incomplete wage contracting with relationship-specific investment into worker skill. He shows that if parties cannot condition the wage contract upon the worker's or the firm's alternative opportunities, then there will be inefficient quits (as in Hall and Lazear (1984) discussed above). The result is a wage contract at which the worker and the firm share the rents from firm-specific investments, as hypothesized by Becker (1962) and Mincer (1962).

This result assumes that the worker and the firm can commit to a fixed wage contract. If that is not possible, then the current wage is always set by ex post renegotiation, which can be expected to lead to an ex post efficient allocation when information is symmetric. Grout (1984) has shown that this leads to the worker's capturing a positive fraction of the rent created by the firm's investments, which in turn leads to lower investment by the firm and slower employment growth. Grout's goal is to model the implications 
of a U.K. law making it impossible to enforce wage agreements between a union and a firm. Even when such commitment is possible, Hart and Moore (1988) show that the fact that the worker and the firm can voluntarily renegotiate a contract in the face of new information implies that in general the first best cannot be achieved with a binding agreement.

However, Carmichael and MacLeod (2003) show that if parties can agree upon a fair division rule that divides the gains to trade in proportion to the investments made by each party, then the first best can be achieved even in the absence of a binding complete contract. Such a rule requires one party to penalize the other should the agreement be perceived as unfair. In the context of union-firm bargaining, there is some recent evidence that unions do retaliate when it is perceived that the wage bargain is unfair. Krueger and Mas (2004) show that a dispute between Firestone and their union led to lower-quality tires. Mas (2006) finds that the resale value of Caterpillar products fell for equipment built during a labor dispute, suggesting again that labor unrest resulted in lower product quality. Finally, Mas (2008) finds that when police unions in New Jersey got adverse rulings in arbitration that led to lower wages, the police reduced their effort as measured by arrest rates.

These results fit in with an extensive literature, beginning with Akerlof (1982), that the extent to which a worker believes that treatment is fair affects productivity (see in particular the work by Bewley (1999) and Fehr and Schmidt (1999)). The holdup model provides an elegant explanation of why fairness is so important. The economic model predicts that investment into a relationship is a function of the return from such an investment. Note that after an investment has been made, however, it is a sunk cost, and hence rational choice theory would predict that any agreement made after investments have been made should be independent of these investments. Consequently, the only way compensation can be linked to investments ex post is for parties to follow a social norm that links them-in other words, parties should believe and enforce a norm of fairness that results in parties who invest more receiving more compensation. Carmichael and MacLeod (2003) provide a general proof of the existence of such norms. See also the work of Hart and Moore (2004), who argue that contracts can act as efficiency-enhancing focal points.

Such models have a potential to provide an efficiency-based explanation of why unions with bargaining power can enhance firm productivity. The next section discusses some of the empirical evidence in this regard. This perspective may also provide some insights into the decline in unionization that has occurred in the private sector in the United States (see Farber and Western (2001)). The issue is whether or not there exist alternatives to unions that enhance the productivity of the employment relationship. First, there is the possibility that employment law is a substitute for union protection. At the moment, we simply do not have any studies that explore this idea. Acemoglu and Pischke (1998) show that firm-sponsored investment into training can be enhanced by the fact that firms have superior knowledge regarding worker productivity. In Acemoglu and Pischke (1999), they also argue that increased employment protection enhances firmsponsored training. They suggest that firm-sponsored training is higher in Europe than in the United States due to higher employment protection in Europe. We do know if the increase in employment protection in the US has lead to more training. MacLeod and Nakavachara (2007) introduce a model with investment and 
asymmetric information, and show that increased employment regulation in the US would lead to a more productive relationship for highly skilled workers.

For lower-skilled workers, Autor (2003) has documented the fact that there has been an increase in temporary help agencies in the United States. He finds that this is in part explained by the increase in employment protection. However, Autor (2001) also documents that as an organizational form, temporary help agencies play a significant role in screening and training of workers.

\subsection{Summary}

In this section, we have reviewed the literature on the theory of the employment relationship from the perspective of transaction-costs economics and contract theory. From this research, we learn that an optimal employment contract is shaped by many factors in addition to the demand and supply of factors of production. The need to provide insurance to workers underlies many of the contributions, in part because this model is quite elegant and can in many situations deliver clear predictions. One prediction that it does not deliver is a theory of why employment relations can entail conflict, and why the allocation of bargaining power has important efficiency consequences.

Models of asymmetric information naturally deliver a theory of conflict, and can explain why parties for whom trade is efficient may fail to reach an agreement (see Crawford (1982)). The vast majority of work on employment focuses on the case in which the asymmetric information concerns the outside options for the worker and firm. Many of the employment disputes discussed in the previous section deal with disagreements concerning what happened within the relationship. The model in Simon (1951) is a useful starting point for thinking about these issues, but currently there is little work on the role of the courts in finding facts in employment cases. ${ }^{50}$ The main message here, consistent with the work of Milgrom (1988), is that the efficient contract for task assignments is to give the informed party decision rights. Chakravarty and MacLeod (2009) discuss how the law can achieve this goal in the context of construction contracts. The way the law achieves the formal allocation of authority within an employment relationship has not been explored in detail, however. Williamson (1991) makes the point that for the most part courts do not intervene in the day-to-day management of employees. The question of how various employment law doctrines affect this authority relationship is still an open question.

The provision of incentives to make relationship-specific investments gives the third motivation for entering into a binding contract. What is interesting is that the contractual instruments here-specifically, the allocation of authority and bargaining power-also play a central role in achieving efficient investment. There is a need for work that helps us understand which, if any, of these theories provide the most useful way to think about the employment contract. The theories by themselves are not typically framed in terms of making causal inferences. Rather, they make predictions regarding how variations in match characteristics ( $X$ variables) are related to observed features of the relationship (wages, employment, bonus or severance pay).

\footnotetext{
${ }^{50}$ See MacLeod and Nakavachara (2007) and Stahler (2008) for a start.
} 
There is some recent work by Cahuc et al. (2006) and Postel-Vinay and Robin (2002) that uses the holdup model of wage determination developed in MacLeod and Malcomson (1993) to empirically estimate models of wage and employment determination. Cahuc et al. (2006) find that only highly skilled workers have significant bargaining power, while low-skilled workers have none. Postel-Vinay and Robin (2002) find in a panel with French data that personal characteristics tend to be more important for highly skilled workers. These are not causal exercises, but they do suggest that employment law is more likely to be important for highly skilled workers.

\section{The Evidence}

The theory of transaction costs provides an economic rationale for intervention into labor markets. Each of the models we have discussed capture some features of the employment relationship that seem empirically plausible. The next step is to see whether changes in employment law do improve matters. We discuss two sets of empirical results that illustrate a range of approaches. First, we review the literature on the employment contract suggesting that there are likely to be mechanisms by which employment law and unions affect the efficiency of labor markets. Second, we review the literature that asks to what extent unions enhance productivity.

\subsection{Employment Law}

In terms of Rubin's model, the unit of analysis for employment laws are typically governments. The most common outcome variables are employment per unit of population, wages, the unemployment rate, and GDP growth. The issue then is, how does a change in employment law change these outcome variables? This is a very difficult question because many events occur along with changes in the law that make it difficult to identify a causal effect. Surprisingly, the results tend to be relatively consistent. The majority of studies find either no effect or a negative effect of increasing employment protection. The results of this work are summarized in Table 2. We do not discuss all of these papers, but note that they can be divided into three broad classes: cross-sectional country studies, cross-sectional country studies with time, and the studies from the United States and India that use within-country state variation.

A good starting point are the cross-country studies. Botero et al. (2004) gather data from a several sources to construct measures of various types of employment regulation, including hours restrictions and dismissal procedures. They find that stricter employment protection is associated with countries whose law originated in the civil law tradition. For these countries, it is found that labor force participation is lower and unemployment is higher. Of course, these statements are not causal, but rather say that there is a covariation between legal origins and employment performance. Djankov et al. (2003) show that civil codes

make it more costly to use the courts for contract enforcement, but even this evidence is not necessarily causal. For example, if judges in civil law countries are more corrupt, then the more bureaucratic rules may be a response to this corruption. These basic results have recently be replicated by Djankov and Ramalho 
(2009), and hence there appears to be a relationship. The question is, why?

A natural way to control for cross-country variations is to use variation over time in laws. Early studies along these lines include the influential work of OECD (1993). They found that employment protection increased jobless duration. In subsequent work, the OECD (2003) finds that employment protection is often insignificant, but is associated with increased unemployment for prime-age males. These, like the cross-section studies, must construct measures of employment protection that are meaningful in different countries. The difficulty, as we see in Table 3, is that there are a large number of possible laws, each of which get implemented in an idiosyncratic fashion. One way to deal with this complexity is to have a more narrow study of a law change. A series of studies by Kugler (1999), Kugler (2004a), and Kugler (2005) uses the 1990 market-based reforms in Columbia. Kugler finds that these reforms generally lead to more flexible labor markets and lower unemployment.

Given that these changes occurred at a single point in time, this implies a true causal effect under the hypothesis that other secular changes would not have produced this effect. One way to satisfy this assumption is to narrow the analysis to a set of units that are more similar, but face changes at different times. Besley and Burgess (2004) pioneered this approach using variations in employment law across states in India. Given that all the units (states) are in the same country, this controls for legal origin. Using data from 1958-1992 on employment law legislation, Besley and Burgess (2004) find that pro-worker legislation lowers economic growth. Similar results have been replicated by Aghion (2008) and Ahsan and Pages (2009). However, given the large cultural diversity in India, one might question the extent to which the law is exogenous to other events in society.

Possibly, the most convincing studies on the effect of the law exploit the fact that in the United States employment law is under state jurisdiction. One can then estimate the effect that state level changes in exceptions to employment at will have on the labor market. These law changes for the 1983-95 period are illustrated in Figure 1. As we can see, a large number of states adopted the implied-contract and publicpolicy exceptions during this time period. In this case, the identifying assumption is that U.S. states are sufficiently similar that one can assume that the impact of the law in each state is similar. One then uses a generalization of model 1:

$$
y_{u t}=\beta^{\top} X_{u t}+\beta_{l}^{\top} l_{s t}+\phi_{u t},
$$

where $u$ denotes state. In most papers, the Current Population Survey (CPS) is used to measure employment and wages by state. Bertrand et al. (2004) show that one cannot assume that the error term $\phi_{u t}$ is i.i.d, and one must allow for correlation over time. In practice this is achieved by adding state-specific time trends and computing standards errors with clustering of the errors at the state level (in effect allowing arbitrary covariance over time within states, but assuming independent errors across states). 
Figure 1: Pattern of Employment Law Adoption during 1983-1994
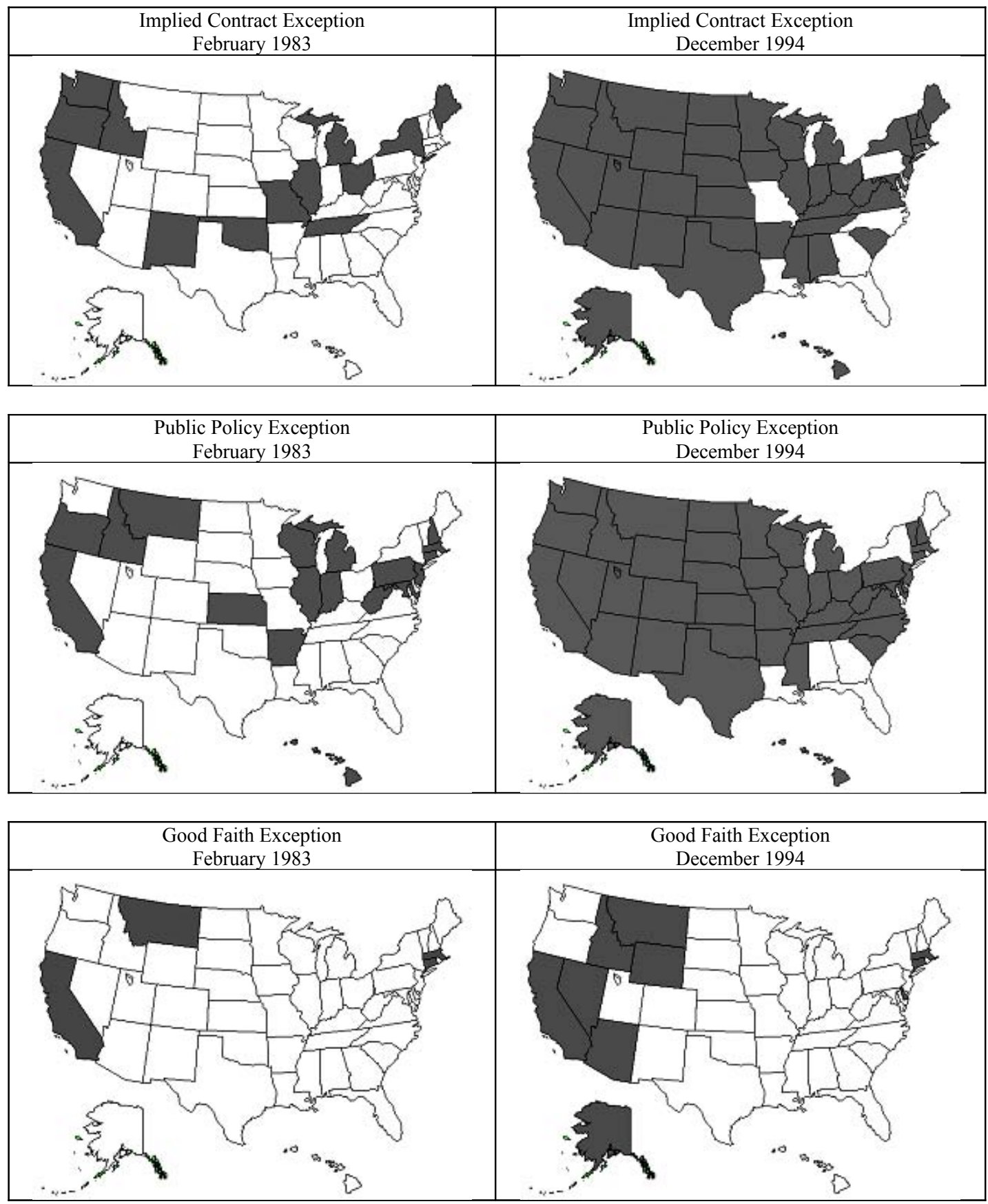
Miles (2000) is an early study by a legal scholar who carefully ensured that employment law is correctly coded. This can be difficult in the United States because law is created by both the courts and the states. He finds very little effect on employment from any of the law variables, but finds that the implied contract exception leads to an increase in temporary employment, consistent with the later work of Autor (2003). Autor et al. (2004) and Autor et al. (2006) further refine the law variables used by Miles (2000), finding that the implied-contract exception leads to a robust reduction in state employment, but that the public-policy and good-faith exceptions have no effect.

The theory discussed above predicts that the effect of the law depends upon the characteristics of the employment relationship. In particular, if hold-up is the transaction cost most responsible for the creation of employment law, then we would expect the law to have more effect on matches with higher levels of relationship-specific investment. This idea motivates the work of MacLeod and Nakavachara (2007). They match the CPS job training supplement that measures the amount of skill in a job with occupation code to divide occupations in the low, middle, and high skill. They then use the data created by Autor et al. (2004) to explore the effect of relating skill requirement with the law. They find that the negative effects of the implied contract and good faith exceptions tend to be concentrated in low-skill (high-turnover) jobs. In fact, the good faith exception has a positive effect on employment for high-skill workers.

Though this appears to be at odds with the previous literature, it should be noted that the earlier literature focuses on the average effects, which obscures the effect on different subgroups. One of the messages from the recent research on contract theory is that optimal contract form should be sensitive to characteristics of the job, particularly for high-performance jobs. Consequently, we cannot obtain a complete understanding of how the law works without taking into account its impact on different types of relationships. Both the theory and the early work of Freeman and Medoff (1984) predict that if transaction costs are a significant source of inefficiency in employment relationships, then there is a role for unions to enhance performance.

\subsection{The Effect of Unions}

Table 4 provides a list of studies that explore the effect of unions upon firm productivity. The early studies by Brown and Medoff (1978) and Clark (1980b) explicitly recognize that unions may enhance performance by increasing investments in firm-specific human capital, improving worker morale and other organizational parameters. Clark (1980b) also observes that union contracts have many terms that address issues in the workplace other than compensation. Brown and Medoff (1978) estimate a Cobb-Douglas production function using data from the May CPS merged with the 1972 Census of Manufacturers (COM). They find that labor productivity is consistently higher at unionized firms. They are careful to point out that this result can be explained by several factors, and while consistent with the hypothesis that unions enhance productivity, they do not establish a causal link.

Clark (1980b) refines this approach by using a time series on U.S. cement plants, which allows one to explore the effect of unions upon plants in the same industry, with precise control on capital equipment. Like Brown and Medoff (1978), Clark finds that unions enhance productivity. One of the interesting findings is 
that if one compares only new plants, then unionized firms have $3.6 \%$ higher productivity, but a lower capital/labor ratio. This is consistent with the holdup model of Grout (1984), which predicts that firms will invest less in physical capital in response to union bargaining power. Abowd (1989) uses stock market data to conclude that unions and firms maximize total wealth.

Recently, developments have begun to focus on workplace organization. ${ }^{51}$ Black and Lynch (2001) find that there is an interaction between workplace practice and unionization. When firms have more consensual decision-making in the workplace, then unionization is associated with higher productivity. Conversely, unions are associated with lower productivity in firms that use "traditional" management practices. Doucouliagos and Laroche (2003) carry out a meta-analysis of a large number of studies on the productivity impact of unions. They find that the evidence is broadly consistent with a positive-productivity effect in the United States and a negative effect in the United Kingdom. This is an interesting observation given that the law is quite different in the two jurisdictions. In the United Kingdom, unions cannot commit to a binding agreement, whereas this is possible in the United States. This difference in productivities is consistent with the evidence, though we are far from having convincing causal evidence.

Even if unions enhance firm productivity, this does not necessarily translate into an increase in profits. This depends on the bargaining power of unions, and the extent to which firms earn rents ${ }^{52}$ A common strategy is to merge National Labor Relations Data on union certification with firm stock-market data to look at the impact of certification on profits. Ruback and Zimmerman (1984) find that unionization causes a 3.8\% fall in equity value. Abowd (1989) finds that unionization can also reduce profits, but that this is an efficient redistribution from firms to workers. These and similar studies must deal with the fact that unionization is endogenous, and hence it is very difficult to estimate the causal impact of a union, independent from other factors. DiNardo and Lee (2004) use a regression discontinuity design in which they compare the outcomes in firms where the unions barely won certification, to ones where there was a close lost. Under the hypothesis that the groups have similar characteristics, then differences can be attributed to union status. Their finding is that the effect is essentially zero.

Lee and Mas (2009) use a similar approach, but obtain a better measure of abnormal stock-market returns. They find that unionization causes a $10 \%$ decline in abnormal returns. What is particularly interesting (especially in the light of the efficient-markets hypothesis) is that the negative effect is largest a year after the vote for unionization. This result is consistent with the body of research that looks at the impact of unions on firm productivity (see Doucouliagos and Laroche (2009)). Even if unions truly enhance productivity, if they lower profitability then we should expect firms to reallocate resources to jurisdictions with less union penetration. Kuhn (1998) suggests that there seems to be little evidence of this in Canada, while Machin (2000) finds that new firms in the United Kingdom tend not be unionized.

As Farber and Western (2001) documents for the United States, and Machin (2000) for the United Kingdom, there has a been a large decline in unionization that is consistent with the hypothesis of excessive rent extract by unions in the face of alternative, non-union, investment opportunities for firms. Yet, there

\footnotetext{
${ }^{51}$ See Ichinowski and Shaw (2003), and the Handbook chapters by Bloom and Van Reenan (2010) and Oyer and Schaefer (2010).

${ }^{52}$ See Ashenfelter and Johnson (1969) for a classic discussion of union-firm bargaining and associated empirical implications.
} 
are still some areas with significant union presence. For example, workers in the entertainment industry are unionized. This is an industry where highly skilled actors, writers, and musicians must move from job to job, and where for each job there is a large number of potential candidates. In the absence of a union contract, the wage would be set at the talent's opportunity cost, which is likely to be far below the return necessary to make it profitable to invest in his or her particular skill. In this case, a union has the potential to increase the talent pool, though this is a hypothesis that has not been carefully tested.

The other area with significant union presence is the public sector. Ehrenberg et al. (1983) find that unions do not significantly affect productivity for municipal librarians. Byrne et al. (1996) find that unionized police are less effective in dealing with crime. Eberts and Stone (1987) explore the effect of unions upon teacher productivity, finding that on average unionized teachers increase test scores by about $3 \%$. However, their impact is more homogeneous, and they do not do as well with students with above- or below-average ability. In a recent study, Lovenheim (2009) finds that teacher unions raise costs by about $15 \%$ while having no impact on school performance. ${ }^{53}$

In summary, the evidence on unions is consistent with the hypothesis that they do have some bargaining power with respect to the firm. As we discussed in the previous section, bargaining power may allow parties to implement more efficient arrangements. The extent to which this is possible in practice is controversial. It is clear that over the past century we have witnessed a large rise and fall in unionization rates in the United States. The transaction-cost perspective suggests that unions can be viewed as substitutes for legal enforcement of contracts and other forms of labor-market regulation. The fact that employment law in the United States has become stronger in the last 30 years - in the sense of providing more protection for disadvantaged groups ${ }^{54}$ and stronger employment protection—-suggests that private law may be providing a substitute for unionization.

In the case of the public sector, the skills acquired by workers are likely to be job-specific, and moreover the demand for these skills are stable. This suggests that the optimal contract is of a long duration, which may explain why public-sector unions are so prevalent. However, it is extremely difficult to measure publicsector productivity, and hence to evaluate properly the available labor institutions for these relationships. Moreover, it is difficult to argue that public-sector unions are purely rent-seeking organizations. As Blank (1994) documents, the public/private sector wage ratio has been falling in the United States, even while private-sector unionization has been falling. If unions were the main source of wage growth for workers, then we should observe the opposite. We do not have definite answers to any of these questions, and hence there is much room for further research.

\footnotetext{
${ }^{53}$ See Eberts (2007) for a general discussion of the role of teacher unions in education.

${ }^{54}$ See Chay (1998), Oyer and Schaefer (2002), and Jolls and Prescott (2004) for studies of the labor-market impact of legislation to protect civil rights and disabled individuals.
} 


\section{Discussion}

There is a remarkable consensus that increased employment protection law tends to reduce employment for individuals with less attachment to the labor market. Increases in employment protection law tend to adversely affect matches at the margin. That being said, the economics research uses a relatively crude representation of the law. We know virtually nothing about how specific legal rules interact with different types of worker-firm matches.

At a policy level, employment protection entails changes to specific rules, such as the number of days' notice for a dismissal, mandatory dismissal payments, and specification of the conditions under which a protected employee may be dismissed. At the moment, policymakers have little guidance on how to set these parameters, aside from the blanket recommendation to reduce them all.

Our discussion of the law illustrates that rules evolve in response to specific issues that need to be addressed in the labor market. In the case of common law rules, as in the United States or United Kingdom, a judge may create law in response to a specific set of facts, yet this new law affects all matches. This process is not well understood. The benefit of common-law rule making is that it usually restricts itself to the bounds of particular cases, and therefore is not speculative. However, though judges are aware and are certainly concerned with the broad impact that a decision may have, there is no systematic feedback mechanism for evaluating the consequences of these rule changes. ${ }^{55}$

In a global context, we see a great deal of competition between different legal systems. Firms may opt out of the courts completely by relying upon mandatory arbitration. However, arbitration courts are increasingly looking like public courts, where there is a long process of deposing witnesses and presentation of volumes of evidence before a decision is reached. More generally, all adjudication systems consist of evidence-collection and decision-making that complement the employment practices used by a firm. We need to better understand the substantive role that these courts play in the complex problem of managing human resources. ${ }^{56}$ The literature on employment law has focused on turnover costs. Yet, the discussions of both the law and the literature on transaction costs suggest that information costs are key to understanding the role that the courts play in handling disputes.

In addition, the focus on turnover costs fails to deal with the selective nature of court decisions. The courts are a venue of last resort for a party who feels that another party has breached a duty. This implies that the law is not applied equally to all individuals. All contracts in the United States are subject to the rule of good faith and fair dealing, which is meant to protect individuals from others, such as managers who blatantly breach their obligations. An issue that is rarely addressed in the economics literature is the extent to which we need courts to protect individuals who face poor treatment from bad managers. ${ }^{57}$ The law, and employment law in particular, exists to deal with specific extreme cases, and not the average employment relationship. In contrast, empirical research on employment law is focused on the average effect.

\footnotetext{
${ }^{55}$ See Krueger (1991), who suggests that the most important feature of the law for private parties is predictability.

${ }^{56}$ See the chapters by Rebitzer and Taylor (2010) and Bloom and Van Reenen (2010) on human resource management.

${ }^{57}$ For example, Sullivan and von Wachter (2009) show that job loss leads to measurable declines in health; hence, there are real costs for workers who invest in a long-term match with a poor employer.
} 
In this chapter, unions and labor law are discussed as alternative governance structures that may enhance the management of the employment relationship. In theory, allocating more power to workers can be efficiency-enhancing when they have private information that can impact match quality. The difficulty is that such power also results in more rent extraction by workers. The existing evidence is consistent with the hypothesis that union power leads to lower profits for firms. There is also mixed evidence regarding whether or not unions enhance match quality. Unions, like managers, are likely to vary in their ability to strike efficient agreements. Hence, we should not be surprised that there is mixed evidence regarding their effects on match quality. The theory suggests that the rise and fall of unions in the private sector can be explained by the extent to which unions enhance the productive efficiency of firms. At the moment we simply do not have any evidence that explains the observed pattern. ${ }^{58}$

Finally, I have characterized elsewhere the literature on employment law as consisting of three solitudes (see MacLeod (2007b)), namely, that the law, the economic theory of contract, and empirical labor economics each has its own aesthetic and group of scholars that have developed for the most part independently of each other. One reason for this is that the law evolved to deal with the pragmatic issue of how to govern the exchange relationship before the analytic tools were in place to study these phenomena. We can view the existing structure of the law as evidence that the central ingredients of contract theory - the insurance motive, asymmetric information and incomplete contracts - are empirically relevant concepts, though we do not know to what extent they provide the best unifying framework.

Ensuring that the economic theory of contract is empirically relevant is not helped by the fact that the theory evolved out of the need to extend the reach of general equilibrium theory, which itself developed from the mathematically sophisticated models of Arrow (1951) and Debreu (1959). The important work of Hart (1975) illustrates a fundamental shortcoming of this approach and shows that when markets are incomplete we cannot expect competitive equilibria to achieve an efficient outcome. This work illustrates that simply extending the model of general equilibrium to deal with incomplete markets is not likely to be a fruitful path.

As discussed in section 3, the subsequent literature on game theory and mechanism design developed a theory that is much more specific to the nature of individual transactions, and allows one to link transactions costs to the observed structure of employment contracts. ${ }^{59}$ The fact that the law has a long and rich history with its own mode of thought and language has made it difficult to link these abstract models of contract theory to legal practice. The work of Oliver Williamson (1975) appeared before much of modern contract theory was developed, and hence his analysis has roots in the legal tradition. As a consequence, his work develops a language that has been influential in introducing the notion of a transaction cost to law and economics, though at the cost of making it very difficult for the scholar schooled in modern theory to tease out the empirical implications of the theory.

In contrast, the third solitude of empirical labor economics uses the model of a competitive market as developed by Marshall (1948) and Samuelson (1947) to successfully organize vast quantities of data on

\footnotetext{
${ }^{58}$ See Farber and Western (2001) for an explanation for the decline.

${ }^{59}$ See in particular the recent books by Laffont and Maritmort (2002) and Bolton and Dewatripont (2005).
} 
employment and wages, as we can see in the first three volumes of the Handbook of Labor Economics. The goal of the empirical literature reviewed in section 4 is to establish a causal link between changes in law and the union status of workers and the change in employment and wages. Such identification is more credible the closer it is to approximating the treatment-control paradigm that is widely used in science. Hence, there is a bias in this literature towards studying changes that occur over fairly short time periods. ${ }^{60}$ Yet the economic theory of contract highlights the fact that individuals enter into agreements because they expect that these relationships will be rewarding in the future, sometimes the distant future. The temporal distance between cause and effect makes it very difficult to explore the implications of these models.

The essence of a contract is that we voluntarily give up freedom of action in the expectation that this reduction will make us better off. It is a fact of life that these great expectations are often dashed, requiring changes to our plans. The history of employment and labor law can be viewed as a sequence of changes that were brought about in the expectation of improving the lives of workers in the long run. We certainly need better ways to measure and evaluate these expectations, so that we may find the optimal trade-off between opportunities of the moment and those that require durable investment and commitment. There is a growing literature that is beginning to explore these issues and the interplay between law and long term outcomes. Harrison and Scorse (2010) explore the effect of anti-sweatshop campaigns and find that they lead to higher wages, with little employment lost. Fiess et al. (2010) explore the impact of informal labor markets upon growth.

Finally, Sullivan and von Wachter (2009) show that job lost leads to higher worker mortality. This research is very important because it illustrates why the pecuniary costs and benefits of job lost cannot fully capture the effect of job lost upon individual well being. This can help explain why employment and labor law have for centuries played such an important role in civil society, and why we need more research on the interplay between law, employment contracts, and labor market performance.

\section{References}

Aвоwd, J. M. (1989): “The Effect of Wage Bargains On the Stock-market Value of the Firm,” American Economic Review, 79, 774-800.

Acemoglu, D. And J.-S. PischKe (1998): "Why do firms train? Theory and evidence," Quarterly Journal of Economics, 113, 79-119.

(1999): “The Structure of Wages and Investment in General Training," Journal of Political Economy, $107,539-572$.

ACEMoglu, D. AND R. SHIMER (1999): “Efficient Unemployment Insurance,” Journal of Political Economy, 107, 893-928.

\footnotetext{
${ }^{60}$ See Lemieux and MacLeod (2000) for a study where we show that previous studies could not properly identify the effect of unemployment insurance parameters because they ignore learning effects that take many years to work their way through the system.
} 
Addison, Teixeira, And Grosso (2000): "The Effect of Dismissals Protection on Employment: More on a Vexed Theme," Southern Economic Journal, 67, 105-122.

Aghion, E. A. (2008): “The Unequal Effects of Liberalization: Evidence from Dismantling the License Raj in India," American Economic Review, 98, 1397-1412.

Aghion, P., M. Dewatripont, And P. Rey (1994): "Renegotiation Design with Unverifiable Information,", Econometrica, 62, 257-282.

Aghion, P. And B. Hermalin (1990): "Legal Restrictions on Private Contracts Can Enhance Efficiency," Journal of Law, Economics, and Organization, 6, 381-409.

Aghion, P. And J. Tirole (1997): “Formal and Real Authority in Organizations," Journal of Political Economy, 105, 1-29.

AhSAn AND PAGes (2009): "Are All Labor Regulations Equal? Evidence from Indian Manufacturing," Journal of Comparative Economics, 37, 62-75.

AKerlof, G. A. (1982): "Labor Exchange as Partial Gift Exchange," Quarterly Journal of Economics, 97, 543-69.

Alchian, A. AND H. Demsetz (1972): "Production, Information Costs, and Economic Organization,," American Economic Review, 62, 777-795.

AlLEN (1984): “Unionized Construction Workers are More Productive,” QJE, 99, 251-274.

Allen, S. G. (1986): "The Effect of Unionism On Productivity In Privately and Publicly Owned Hospitals and Nursing-homes," Journal of Labor Research, 7, 59-68.

Altonji, J. G. AND R. M. BlAnK (1999): "Race and Gender in the Labor Market," in Handbook of Labor Economics Volume 3C, ed. by O. Ashenfelter and D. Card, Amsterdam: North-Holland, 3143-3260.

AMIN (2009): “Labor Regulation and Employment in India's Retail Stores," Journal of Comparative Economics, 37, 47-61.

Andreoni, J. And C. Sprenger (2010a): "Certain and Uncertain Utility: The Allais Paradox and Five Decision Theory Phenomena,” Tech. rep., University of California, San Diego.

- (2010b): "Risk Preferences are Not Time Preferences," Tech. rep., University of California, San Diego, February.

Angrist, J. D., G. W. Imbens, And D. B. Rubin (1996): "Identification of causal effects using instrumental variables," Journal of the American Statistical Association, 91, 444-455.

AOKI, M. (2001): Towards a Comparative Institutional Analysis, CAmbridge, MA: MIT Press. 
ARrow, K. J. (1951): "An Extension of the Basic Welfare Theorems of Classical Welfare Economics," in Proceedings of the Second Berkeley Symposium on Mathematical Statistics and Probability, ed. by J. Neyman, Berkeley, California: University of California Press, 507-532.

Ashenfelter, O. And G. E. Johnson (1969): "Bargaining Theory, Trade Unions, and Industrial Strike Activity," American Economic Review, 59, 35-49.

Autor, D. H. (2001): “Why Do Temporary Help Firms Provide Free General Skills Training?” Quarterly Journal of Economics, 116, 1409-48.

(2003): "Outsourcing at Will: the Contribution of Unjust Dismissal Doctrine to the Growth of Employment Outsourcing," Journal of Labor Economics, 21, 1-42.

Autor, D. H., J. J. Donohue, And S. J. Schwab (2004): “The employment consequences of wrongfuldischarge laws: Large, small, or none at all?” American Economic Review, 94, 440-446.

- (2006): “The Costs of Wrongful-Discharge Laws," Review of Economics and Statistcs, 88, 211-231.

Autor, D. H., W. R. KerR, AND A. D. Kugler (2007): "Does Employment Protection Reduce Productivity? Evidence from US States,” The Economic Journal, 117, F189-F213.

AZARIADIS, C. (1975): "Implicit Contracts and Underemployment Equilibria," Journal of Political Economy, 83, 1183-1202.

BAILY, M. N. (1974): "Wages and Employment under Uncertain Demand," Review of Economic Studies, $41,37-50$.

BAKer, T. (2003): Insurance Law and Policy, Aspen Publishers.

BeAudry, P. AND J. DiNARdo (1991): “The Effect of Implicit Contracts on the Movement of Wages over the Business Cycle: Evidence from Micro Data," Journal of Political Economy, 99, 665-688.

BECKER AND OLSON (1990): “The Effects of the NLRA on Stockholder Wealth in the 1930s," ILRR, 44, $116-129$.

— (1992): “Unions and Firm Profits," Industrial Relations, 31, 395-416.

BECKer, G. (1962): "Investment in Human Capital: A Theoretical Analysis," Journal of Political Economy, 70, 9-49.

Bemmels, B. (1987): “How Unions Affect Productivity In Manufacturing Plant," Industrial \& Labor Relations Review, 40, 241-253.

Bentolila, S. And G. Bertola (1990): "Firing Costs and Labour Demand: How Bad is Eurosclerosis?" Review of Economic Studies, 57, 381-402. 
Bertrand, M., E. Duflo, And S. Mullainathan (2004): "How much should we trust differences-indifferences estimates?" Quarterly Journal of Economics, 119, 249-275.

Besley, T. AND R. BuRgess (2004): "Can labor regulation hinder economic performance? Evidence from India," Quarterly Journal of Economics, 119, 91-134.

BEWLEY, T. F. (1999): Why wages don't fall during a recession, Cambridge and London: Harvard University Press.

BIRD, R. C. AND J. D. KNOPf (2009): “Do Wrongful-Discharge Laws Impair Firm Performance?” Journal of Law \& Economics, 52, 197-222.

BLACK, S. E. AND L. M. LyNCH (2001): "How to compete: the impact of workplace practices and information technology on productivity," Review of Economics and Statistics, 83, 434-445.

BLANCHARD AND WOLFERS (2000): "The Role of Shocks and Institutions in the Rise of European Unemployment: the Aggregate Evidence,” Economic Journal, 119, 1339-1382.

BlAnCHARD, O. J. AND J. TIROLE (2008): "The joint design of unemployment insurance and employment protection: A first pass," Journal of the European Economic Association, 6, 45-77.

Blank, R. M. (1994): "Public Sector Growth and Labor Market Flexibility: the United States vs. the United Kingdom," in Social Protection Versus Economic Flexibiolity: is there a Trade-off?, University of Chicago Press.

Blanpain, R. (2003): European labour law, The Hague ; Boston: Kluwer Law International, 9th and rev. ed.

BlaU, F. AND L. KAHN (1999): "Institutions and Laws in the Labor Market," in Handbook of Labor Economics Volume 3A, ed. by O. Ashenfelter and D. Card, Amsterdam: North-Holland, 1399-1461.

Blinder, A. S. AND D. H. ChOI (1990): “A Shred of Evidence on Theories of Wage Stickiness,” Quarterly Journal of Economics, 105, 1003-1015.

Bloch, M. (1961): Feudal Society, Routledge \& Kegan Paul.

Bloom, N. And J. Van Reenen (2010): "Human Resource Managment and Productivity," in Handbook of Labor Economics, Volume 4, ed. by O. Ashenfelter and D. Card, Elsevier, vol. 4, chap. 19.

Bolton, P. And M. Dewatripont (2005): Contract Theory, Cambridge, MA: MIT Press.

Botero, J. C., S. Djankov, R. La Porta, F. Lopez-de Silanes, And A. Shleifer (2004): “The regulation of labor," Quarterly Journal of Economics, 119, 1339-1382.

Breiman, L. (2001): “Statistical modeling: the two cultures," Statistical Science, 16, 199-215. 
Breyer, S. (2009): “Economic Reasoning and Judicial Review,” Economic Journal, 119, F215-F135.

Bronars, S. And D. Deere (1994): "Unionization and Profitability - Evidence of Spillover Effects," Journal of Political Economy, 102, 1281-1287.

Bronars, S. G. AND D. R. DeERE (1990): “Union Representation Elections and Firm Profitability," Industrial Relations, 29, 15-37.

Brown, C. And J. L. Medoff (1978): "Trade Unions in the Production Process," Journal of Political Economy, 86, 355-378.

Burguet, R. AND R. CAminal (2008): “Does the market provide sufficient employment protection?" Labour Economics, 15, 406-422.

Byrne, D., H. DezhbakhSh, AND R. KING (1996): "Unions and police productivity: An econometric investigation," Industrial Relations, 35, 566-584.

Caballero, R. J., K. N. Cowan, E. M. Engel, And A. Micco (2004): "Effective Labor Regulation and Microeconomic Flexibility," NBER Working Paper No. 10744.

CAhUC, P., F. Postel-Vinay, And J. Robin (2006): "Wage bargaining with on-the-job search: Theory and evidence," Econometrica, 74, 323-364.

CARD, D. (1986): "Efficient Contracts with Costly Adjustment: Short-Run Employment Determination for Airline Mechanics," American Economic Review, 76, 1045-1071.

CARD, D., F. DEvicienti, AND A. MAidA (2010): "Rent-sharing, holdup, and wages: evidence from matched panel data,” Tech. Rep. 16192, NBER.

CARD, D. AND D. Hyslop (1997): “Does Inflation 'Grease the Wheels of the Labor Market'?" in Reducing Inflation: Motivation and Strategy, ed. by C. D. Romer and D. H. Romer, Chicago, IL: University of Chicago Press.

Carmichael, H. L. And W. B. Macleod (2003): "Caring About Sunk Costs: A Behavioral Solution to Hold-Up Problems with Small Stakes," Journal of Law, Economics and Organization, 19, 106-118.

Chakravarty, S. And W. B. MacLeOd (2009): "Contracting in the shadow of the law," Rand Journal of Economics, 40, 533-557.

ChAY, K. Y. (1998): "The Impact of Federal Civil Rights policy on Black Economic Progress: Evidence from the Equal Employment Opportunity Act of 1972," Industrial and Labor Relations Review, 51, 608632.

Che, Y.-K. AND D. B. HAusch (1999): “Cooperative Investments and the Value of Contracting," American Economic Review, 89, 125-47. 
Chiappori, P.-A., B. SAlanié, And J. Valentin (1999): "Early Starters Versus Late Beginners,” Journal of Political Economy, 107, 731-60.

ClARK, K. B. (1980a): “The Impact of Unionization On Productivity - A Case-study," Industrial \& Labor Relations Review, 33, 451-469.

- (1980b): "Unionization and Productivity - Micro-econometric Evidence," Quarterly Journal of Economics, 95, 613-639.

- (1984): "Unionization and Firm Performance - the Impact On Profits, Growth, and Productivity," American Economic Review, 74, 893-919.

COASE, R. (1937): “The Nature of the Firm,” Economica, 4, 386-405.

Cochrane, J. H. (1991): “A Simple Test of Consumption Insurance,” The Journal of Political Economy, 99, 957-976.

Cooke, W. N. (1994): "Employee Participation Programs, Group-based Incentives, Company Performance - A Union-nonunion Comparison,” Industrial \& Labor Relations Review, 47, 594-609.

Cousineau, J.-M., R. Lacroix, And D. Bilodeau (1983): "The Determination of Escalator Clauses in Collective Agreements," Review of Economics and Statistics, 65, 196-202.

CRAWford, V. P. (1982): “A Theory of Disagreement in Bargaining,” Econometrica, 50, 607-637. (1988): "Long-Term Relationships Governed by Short-Term Contracts," The American Economic Review, 78, 485-499.

DE BARros, P. AND Corseuil (2004): "The Impact of Regulations on Brazilian Labor Market Performance," in Law and Employment: Lessons from Latin America and the Caribbean, The University of Chicago Press.

Debreu, G. (1959): Theory of Value, New Haven, CT: Yale University Press.

DESSEIN, W. (2002): “Authority and communication in organizations," Review of Economic Studies, 69, 811-838.

Di Tella, R. And R. MacCulloch (2005): “The Consequences of Labor Market Flexibility: Panel Evidence Based on Survey Data,” European Economic Review, 49, 1225-1259.

DiAmOnd, P. A. AND E. MASKin (1979): “An Equilibrium Analysis of Search and Breach of Contract, I: Steady States,” Bell Journal of Economics, 10, 282-316.

DiNARDO, J. AND D. S. LEE (2004): “Economic impacts of new unionization on private sector employers: 1984-2001," Quarterly Journal of Economics, 119, 1383-1441. 
Djankov, S., O. Hart, C. MCLiesh, And A. Shleifer (2008): "Debt Enforcement around the World," Journal of Political Economy, 116, 1105-1150.

Djankov, S., R. La Porta, F. Lopez-De Silanes, And A. Shleifer (2003): “Courts," Quarterly Journal of Economics, 118, 453-517.

Djankov, S. AND R. Ramalho (2009): "Employment Laws in Developing Countries," Journal of Comparative Economics, 37, 3-13.

Doucouliagos, C. AND P. LARoche (2003): "What do unions do to productivity? A meta-analysis," Industrial Relations, 42, 650-691.

Doucouliagos, H. And P. Laroche (2009): “Unions and Profits: A Meta-Regression Analysis," Industrial Relations, 48, 146-184.

Downes, E. A. (2004): "Labor Market Regulation and Employment in the Caribbean," in Law and Employment: Lessons from Latin America and the Caribbean, The Unviersity of Chicago Press.

Dunford, B. B. And D. J. Devin (1998): "Employment At-Will and Employee Discharge: A Justive Perspective on Legal Action Following Termination," Personnel Psychology, 51, 903-934.

Dye, R. A. (1985): “Optimal Length of Labor Contracts,” International Economic Review, 26, 251-270.

Eberts, R. And J. A. Stone (1987): “Teacher Unions and the Productivity of Public Schools," Industrial \& Labor Relations Review, 40, 354-363.

EberTs, R. W. (2007): “Teachers unions and student performance: Help or hindrance?” Future Of Children, 17, 175-200.

Ehrenberg, R. G., D. Sherman, and J. Schwartz (1983): "Unions and Productivity in the Public Sector: A Study of Municipal Libraries," Industrial \& Labor Relations Review, 36, 199-213.

EHrlich, I. AND R. A. Posner (1974): “An Economic Analysis of Legal Rulemaking," The Journal of Legal Studies, 3, 257-286.

Elmeskov, Martin, S. (1998): “Key Lessons For Labour Market Reforms: Evidence From OECD Countries' Experience," Swedish Economic Policy Review, 5.

Epstein, R. A. (1984): "In Defense of the Contract at Will," The University of Chicago Law Review, 51, 947-982.

EslavA, E. A. (2004): "The Effects of Structural Reforms on Productivity- and Profitability-Enhancing Reallocation: Evidence from Colombia," Journal of Development Economics, 75, 333-371. 
FARber, H. S. AND B. Western (2001): "Accounting for the Decline of Unions in the Private Sector, 1973-98," Journal of Labor Research, 22, 459-85.

Feess, E. And G. Muehlheusser (2002): "Economic Consequences of Transfer Fee Regulations in European Football," European Journal of Law and Economics, 13, 221-37.

FEhr, E. AND K. M. Schmidt (1999): “A Theory of Fairness, Competition, and Cooperation,” Quarterly Journal of Economics, 114, 817-68.

Feinman, J. M. (1978): “The Development of the Employment at Will Rule,” American Journal of Legal History, 20, 118-135.

FELdmann, H. (2008): "Business regulation and labor market performance around the world," Journal of Regulatory Economics, 33, 201-235.

- (2009): "The unemployment effects of labor regulation around the world," Journal of Comparative Economics, 37, 76-90.

Fiess, N. M., M. FugAzZA, AND W. F. MAloney (2010): "Informal self-employment and macroeconomic fluctuations," Journal of Development Economics, 91, 211-226.

FreEman (2002): “Institutional Differences and Economic Performance Among OECD Countries," CEP Discussion Papers.

Freeman, R. D. AND J. L. Medoff (1984): What do unions do?, New York, NY: Basic Books.

Friedman, M. (1962): Capitalism and Freedom, Chicago: University of Chicago Press, with the assistance of Rose D. Friedman. $23 \mathrm{~cm}$.

Fuller, L. L. AND W. Perdue (1936): “The Reliance Interest in Contract Damages: 1,” The Yale Law Journal, 46, 52-96.

Garibaldi, M. (1999): “Deconstructing Job Creation,” IMF Working Paper No. 99/109.

Gibions, R. (1987): “Piece Rate Incentive Schemes,” Journal of Labor Economics, 5, 413-29.

- (1997): "Incentives and Careers in Organizations," in Advances in Economics and Econometrics: Theory and Applications, ed. by D. M. Kreps and K. F. Wallis, Cambridge, UK: Cambridge University Press, 1-37.

GibBons, R. AND L. F. KATZ (1991): "Layoffs and Lemons," Journal of Labor Economics, 9, 351-80.

Gibbons, R., L. F. Katz, T. Lemieux, and D. Parent (2005): “Comparative Advantage, Learning, and Sectoral Wage Determination," Journal of Labor Economics, 23, 681-723. 
Goetz, C. J. And R. E. ScotT (1980): "Enforcing Promises: An Examination of the Basis of Contract," Yale Law Journal, 89, 1261-1322.

Goldberg, V. P. (1976): “Regulation and Administered Contracts,” Bell Journal of Economics, 7, 426-48.

Gould IV, W. B. (2004): A Primer on American Labor Law, MIT Press.

GreIF, A. (1989): "Reputation and Coalitions in Medieval Trade - Evidence on the Maghribi Traders," Journal of Economic History, 49, 857-882, times Cited: 79.

Grossman, S. J. AND O. D. HaRT (1981): “Implicit Contracts, Moral Hazard,Unemployment," American Economic Review, 71, 301-307.

(1986): “The Costs and Benefits of Ownership: A Theory of Vertical and Lateral Integration," Journal of Political Economy, 94, 691-719.

Grout, P. (1984): "Investment and Wages in the Absence of Binding Contracts: A Nash Bargaining Approach," Econometrica, 52, 449-460.

GrubB And Wells (1993): "Employment Regulation and Patterns of Work in EC Countries," OECD Economic Studies, 21.

GUERRIERI, V. (2008): "Inefficient unemployment dynamics under asymmetric information," Journal of Political Economy, 116, 667-708.

HALl, R. E. AND E. P. LAZEAR (1984): “The Excess Sensitivity of Layoffs and Quits to Demand,” Journal of Labor Economics, 2, 233-257.

HARDIN, G. (1968): “Tragedy of Commons,” Science, 162, 1243-1248.

Harris, M. AND B. Holmström (1982): “A Theory of Wage Dynamics,” Review of Economic Studies, 49, 315-333.

HARrison, A. AND J. SCORSE (2010): "Multinationals and Anti-Sweatshop Activism," American Economic Review.

HART, O. (1975): “On the Optimality of Equilibrium When the Market Structure is Incomplete," Journal of Economics Theory, 11, 418-43.

HART, O. D. (1995): Firms, Contracts and Financial Structure, Oxford, UK: Oxford University Press.

HART, O. D. AND B. HolmstRöm (1987): "The Theory of Contracts," in Advances in Economic Theory: Fifth World Congress., ed. by T. Bewley, Cambridge, U.K.: Cambridge University Press, 71-155.

HART, O. D. AND J. MoORE (1988): “Incomplete Contracts and Renegotiation,” Econometrica, 56, 755785. 
(2004): “Agreeing Now to Agree Later: Contracts that Rule Out but do not Rule In,” Tech. Rep. 10397, NBER, Cambridge, MA.

Hashimoto, M. (1981): "Firm Specific Capital as a Shared Investment," American Economic Review, 71, $475-482$.

Heckman, J. J. And C. PAgÉs (2000): “The Cost of Job Security Regulation: Evidence from Latin American Labor Markets," Economia, 1, 109-154.

Hirsch, B. T. (1991): "Union Coverage and Profitability Among U.S. Firms," Review of Economics and Statistics, 73, 69-77.

Hirsch, B. T. And R. Connolly (1987): “Do Unions Capture Monopoly Profits?” Industrial \& Labor Relations Review, 41, 118-136.

Holland, P. W. (1986): "Statistics and Causal Inference," Journal of the American Statistical Association, 81, 945-960.

Holmes JR., O. W. (1881): The Common Law, Boston, MA: Little, Brown.

Hopenhayn, H. AND J. NicOlini (1997): “Optimal unemployment insurance,” Journal of Political Economy, 105, 412-438.

Hopenhayn, H. And R. Rogerson (1993): "Job Turnover and Policy Evaluation: A General Equilibrium Analysis," Journal of Political Economy, 101, 915-38.

HowitT, P. (2002): "Looking Inside the Labor Market: A Review Article," Journal of Economic Literature, 40, 125-38, tY - JOUR Accession Number: 0603937 . Geographic Descriptors: U.S.. Publication Type: Journal Article. Update Code: 200205.

ICHINOWSKI, C. AND K. SHAW (2003): "Beyond Incentive Pay: Insiders' Estimates of the Value of Complementary Human Resource Management Practices," Journal of Economic Perspectives, 17, 155-180.

Imbens, G. W. AND T. LEMIEUX (2008): “Regression discontinuity designs: A guide to practice,” Journal of Econometrics, 142, 615-635.

Imbens, G. W. AND J. M. WoOldRIDGE (2009): "Recent Developments in the Econometrics of Program Evaluation," Journal of Economic Literature, 47, 5-86.

JACKSON, M. O. (2001): "Mechanism Theory," in The Encyclopedia of Life Support Systems.

Jensen, M. And W. Meckling (1976): "Theory of the Firm: Managerial Behavior, Agency Costs and Ownership Structure," Journal of Financial Economics, 3, 305-60. 
Johnson, S., J. MCMillan, And C. Woodruff (2002): “Courts and Relational Contracts," Journal of Law, Economics, and Organization, 18, 221-77.

Jolls, C. (2007): "Employment Law," in Handbook of Law and Economics, ed. by A. M. Polinsky and S. Shavell, Elsevier, Amsterdam, The Netherlands, vol. 2, chap. 17.

Jolls, C. And J. J. PrescotT (2004): "Disaggregating Employment Protection: the Case of Disability Discrimination,” Tech. rep., National Bureau of Economic Research, Cambridge, MA.

Joskow, P. L. (1988): "Price Adjustment In Long-Term-Contracts - the Case of Coal," Journal of Law \& Economics, 31, 47-83.

KAHN, L. M. (2010): "Employment protection reforms, employment and the incidence of temporary jobs in Europe: 1996-2001," Labour Economics, 17, 1-15.

Kanemoto, Y. And W. B. MacLeod (1992): "The Ratchet Effect and the Market for Second Hand Workers," Journal of Labor Economics, 10, 85-92.

KAPLAN, D. (2009): "Job creation and labor reform in Latin America," Journal of Comparative Economics, $37,91-105$.

KeSSLER, D. AND D. Rubinfeld (2007): "Empirical study of the civil justice system," Handbook of law and economics, 1, 343-402.

Kornhauser, L. And W. B. MacLeod (2011): “Contracts between Legal Persons," in Handbook of Organizational Economics, ed. by R. Gibbons and J. Roberts, Princeton University Press.

KRUEGER, A. AND A. MAS (2004): "Strikes, scabs, and tread separations: Labor strife and the production of defective Bridgestone/Firestone tires,” Journal of Political Economy, 112, 253-289.

Krueger, A. B. (1991): “The Evolution of Unjust-Dismissal Legislation in the United States," Industrial and Labor Relations Review, 44, 644-60.

Kugler, A. (2004a): "The Effect of Job Security Regulations on Labor Market Flexibility: Evidence from the Colombian Labor Market Reform," in Law and Employment: Lessons from Latin American and the Caribbean, ed. by J. J. Heckman and C. Pags, Chicago: The University of Chicago Press.

(2005): "Wage-shifting effects of severance payments savings accounts in Colombia," Journal of Public Economics, 89, 487-500.

Kugler, A. D. (1999): "The impact of firing costs on turnover and unemployment: Evidence from the Colombian labour market reform," International Tax and Public Finance, 6, 389-410.

(2004b): "How do firing costs affect worker flows in a world with adverse selection?" Journal of Labor Economics, 22, 553-584. 
KuHn, P. (1992): “Mandatory Notice,” Journal of Labor Economics, 10, 117-137.

- (1998): "Unions and the economy: what we know; what we should know," Canadian Journal of Economics-Revue Canadienne D'Economique, 31, 1033-1056.

Kuhn, P. And J. Robert (1989): "Seniority And Distribution in a 2-worker Trade Union," Quarterly Journal of Economics, 104, 485-505.

La Porta, R., F. Lopez-de Silanes, And A. Shleifer (2008): "The Economic Consequences of Legal Origins," Journal of Economics Literature, 46, 285-332.

LAFFOnT, J.-J. AND D. MARITMORT (2002): The Theory of Incentives, Pinceton, NJ: Princeton University Press.

LAING, D. (1994): "Involuntary Layoffs In A Model With Asymmetric Information Concerning Worker Ability," Review Of Economic Studies, 61, 375-392.

LAZEAR, E. P. (1990): “Job Security Provisions and Employment," Quarterly Journal of Economics, 105, 699-726.

LeE, D. S. And T. Lemieux (2009): "Regression Discontinuity Designs in Economics,” Tech. Rep. 14723, NBER, Cambridge, MA.

LEE, D. S. AND A. MAS (2009): "Long-Run Impacts of Unions on Firms: New Evidence from Financial Markets, 1961-19991,” Tech. Rep. 14709, Princeton University, Cambridge, MA.

LeE, D. S. And J. MCCRARY (2005): “Crime, Punishment, and Myopia,” Tech. Rep. 11491, NBER, Cambridge, MA.

LemieuX, T. And W. B. MacLeod (2000): "Supply Side Hysteresis: the Case of the Canadian Unemployment Insurance System,” Journal of Public Economics, 78, 139-170.

LEvin, J. (2003): “Relational Incentive Contacts,” American Economic Review, 93, 835-857.

Levine, D. I. (1991): “Just-Cause Employment Policies in the Presence of Worker Adverse Selection," Journal of Labor Economics, 9, 294-305.

Lovell, Sickles, And WARRen (1988): "The Effect of Unionization on Labor Productivity: Some Additional Evidence," Journal of Labor Research, 9, 55-63.

Lovenheim, M. F. (2009): "The Effect of Teachers' Unions on Education Production: Evidence from Union Election Certifications in Three Midwestern States," Journal of Labor Economics, 27, 525-587.

Machin, S. (1991): “The Productivity Effects Of Unionization And Firm Size In British Engineering Firms," Economica, 58, 479-490. 
(2000): “Union decline in Britain,” British Journal of Industrial Relations, 38, 631-645.

MACLEOD, W. B. (2003): “Optimal Contracting with Subjective Evaluation,” American Economic Review, 93, 216-240.

- (2005): "Regulation or markets? The case of employment contracts," Cesifo Economic Studies, 51, 1-46.

- (2007a): "Reputations, Relationships and Contract Enforcement," Journal of Economics Literature, XLV, 597-630.

(2007b): "Three solitudes in contract: Law, data, and theory," Scottish Journal of Political Economy, 54, 606-616.

MacLeod, W. B. And J. M. Malcomson (1989): "Implicit Contracts, Incentive Compatibility, and Involuntary Unemployment," Econometrica, 57, 447-480.

- (1993): "Investments, Holdup, and the Form of Market Contracts," American Economic Review, 83, 811-837.

MacLeod, W. B. And V. NAKaVAchara (2007): "Legal Default Rules: the Case of Wrongful Discharge Laws," Economic Journal, 117, F1-F62.

MACNeIL, I. R. (1974): “The Many Futures of Contracts,” Southern California Law Review, 47, 691-816.

Marshall, A. (1948): The Principles of Economics, New York, NY: Macmillan.

MAS, A. (2006): "Pay, reference points, and police performance," Quarterly Journal of Economics, 121, $783-821$.

- (2008): "Labour unrest and the quality of production: Evidence from the construction equipment resale market," Review of Economic Studies, 75, 229-258.

MatouscheK, N., P. RAmezzanA, And F. RoberT-Nicoud (2009): "Labor market reforms, job instability, and the flexibility of the employment relationship," European Economic Review, 53, 19-36.

MCDonald, I. M. And R. M. Solow (1981): “Wage Bargaining and Employment,” American Economic Review, 71, 896-908.

McLaughlin, K. (1994): “Rigid Wages,” Journal of Monetary Economics, 34, 383-414.

Miles, T. J. (2000): "Common law exceptions to employment at will and US labor markets," Journal of Law Economics \& Organization, 16, 74-101.

Milgrom, P. (1988): “Employment Contracts, Influence Actitivities, and Efficient Organizational Design,” Journal of Political Economy, 96, 42-60. 
Mincer, J. (1962): “On-the-job Training: Cost, Returns and Some Implications," Journal of Political Economy, 70, 50-79.

Mitchell, M. W. And J. A. Stone (1992): "Union Effects On Productivity - Evidence From Western United-states Sawmills," Industrial \& Labor Relations Review, 46, 135-145.

Mondino And Montoya (2004): "The Effects of Labor Market Regulations on Employment Decisions by Firms: Empirical Evidence for Argentina," in Law and Employment: Lessons from Latin America and the Caribbean, The University of Chicago Press.

Montenegro, C. E. And C. Pagés (2004): "Who Benefits from Labor Market Regulations? Chile 19601998," in Law and Employment: Lessons from Latin America and the Caribbean, ed. by J. J. Heckman and C. Pagés, Chicago, IL: The University of Chicago Press, chap. 7, 401-434.

Moore, J. AND R. Repullo (1988): “Subgame Perfect Implementation,” Econometrica, 56, 1191-1220.

Moore, J. H. (1985): "Optimal Labour Contracts When Workers Have A Variety of Privately Observed Reservation Wages," Review of Economic Studies, 52, 37-67.

Morriss, A. P. (1995-1996): "Bad Data, Bad Economics, and Bad Policy: Time to Fire Wrongful Discharge Law," University of Texas Law Review, 74, 1901.

Myerson, R. B. And M. A. Satterthwaite (1983): “Efficient Mechanisms for Bilateral Trading," Journal of Economic Theory, 29, 265-281.

NAidu, S. AND N. Yuchtman (2009): "How Green Was My Valley? Coercive Contract Enforcement in 19th Century Industrial Britain,” Tech. rep., Havard University.

NiCKELL, S. (1997): “Unemployment and Labor Market Rigidities: Europe versus North America," Journal of Economic Perspectives, 11, 55-74.

Nicoletti, G., S. ScARPetta, And P. LAne (2003): "Regulation, productivity and growth - OECD evidence," Economic Policy, 39, 9-72.

OECD (1993): Employment Outlook, OECD.

(1994): The Jobs Study: Evidence and Explanations, Paris, France: OECD.

(1996): Employment Outlook, Paris, France: OECD.

(1999): Assessing Performance and Policy, Paris, France: OECD.

(2003): Employment Outlook, Paris, France: OECD.

Ostrom, E. (2000): "Collective Action and the Evolution of Social Norms," Journal of Economic Perspectives, 14, 137-158. 
OYER, P. AND S. SchaEFer (2002): "Litigation costs and returns to experience," American Economic Review, 92, 683-705.

Pagés, C. And C. E. Montenegro (2007): "Job Security and the Age-Composition of Employment: Evidence from Chile," Estudios de Economia, 34, 109-139.

Pauly, M. V. (1968): “The Economics of Moral Hazard,” American Economics Review, 58, 531-537.

PEIERLS, R. E. (1960): “Wolfgang Ernst Pauli. 1900-1958," Biographical Memoirs of Fellows of the Royal Society, 5, 175-192.

PISSARIDES, C. A. (2001): “Employment Protection,” Labour Economics, 8, 131-59.

Posner, R. (2008): How Judges Think, Harvard University Press.

Posner, R. A. (1974): “Theories of Economic Regulation,” The Bell Journal of Economics and Management Science, 5, 335-358, fLA 00058556 American Telephone and Telegraph Company Copyright 1970 American Telephone and Telegraph Company.

- (2003): Economic Analysis of Law, 6th Edition, Boston, USA: Little, Brown and Company, 6th edition ed.

POSTEL-Vinay, F. AND J. ROBIN (2002): "Equilibrium wage dispersion with worker and employer heterogeneity," Econometrica, 70, 2295-2350.

PRIES, M. AND R. Rogerson (2005): "Hiring policies, labor market institutions, and labor market flows," Journal of Political Economy, 113, 811-839.

Rebitzer, J. B. AND L. J. TAylor (2010): "Extrinsic Rewards and Intrinsic Motives: Standard and Behavioral Approaches to Agency and Labor Markets," in Handbook of Labor Economics, Volume 4, ed. by O. Ashenfelter and D. Card, Elsevier, vol. 4, chap. 8.

Rogerson, R., R. Shimer, AND R. Wright (2005): "Search-theoretic models of the labor market: A survey," Journal of Economic Literature, 43, 959-988.

Rogerson, W. P. (1984): "Efficient Reliance and Damage Measures for Breach of Contract," RAND Journal of Economics, 15, 39-53.

(1992): “Contractual Solutions to the Hold-up Problem,” Review of Economic Studies, 59, 777-793.

Rosen, S. (1985): “Implicit Contracts: A Survey," Journal of Economic Literature, 23, 1144-75.

Rothstein, M. A. And L. Liebman (2003): Employment Law, New York, NY: Thomson West.

Ruback, R. S. AND M. B. Zimmerman (1984): "Unionization and Profitability: Evidence from the Capital Market," Journal of Political Economy, 92, 1134-1157. 
SaAvedra, J. And M. Torero (2004): "Labor Market Reforms and Their Impact on Formal Labor Demand and Job Market Turnover: the Case of Peruaa," in Law and Employment: Lessons from Latin America and the Caribbean, The University of Chicago Press.

SALINGER (1984): “Tobin's Q, Unionization, and the Concentration-Profits Relationship,” The RAND Journal of Economics, 15, 159-170.

Samuelson, P. (1947): Foundations of Economic Analysis, Harvard University Press.

ScARpetta, S. (1996): "Assessing the Role of Labour Market Policies and Institutional Settings on Unemployment: A Cross-Country Study," OECD Economic Studies.

Schwartz, A. And R. E. ScotT (2003): “Contract Theory and the Limits of Contract Law," The Yale Law Journal, 113, 541-619.

Shaked, A. And J. SutTon (1984): "Involuntary Unemployment as a Perfect Equilibrium in a Bargaining Model," Econometrica, 52, 1351-1364.

Shapiro, C. AND J. E. STIglitz (1984): "Equilibrium Unemployment as a Worker Discipline Device," American Economic Review, 74, 433-444.

SHAVELL, S. (1984): “The Design of Contracts and Remedies for Breach,” Quarterly Journal of Economics, 99, 121-48.

Simon, H. (1957): Administrative Behavior, New York: The MacMillan Company.

Simon, H. A. (1951): “A Formal Theory of the Employment Relationship,” Econometrica, 19, 293-305.

STAHLER, N. (2008): "Firing costs, severance payments, judicial mistakes and unemployment," Labour Economics, 15, 1162-1178.

Stephenson, M. C. (2009): "Legal Realism for Economists," Journal of Economic Perspectives, 23, 191-211.

Sullivan, D. AND T. von WAChter (2009): "Job Displacement And Mortality: An Analysis Using Administrative Data," Quarterly Journal Of Economics, 124, 1265-1306.

Tirole, J. (1999): “Incomplete Contracts: Where do we Stand?” Econometrica, 67, 741-782.

TownsEnd, R. M. (1994): “Risk and Insurance in Village India,” Econometrica, 62, 539-591.

VON WACHTER, T. (2007): "In the Right Place at the Wrong Time: the Role of Firms and Luck in Young Workers' Careers," American Economic Review.

Voos AND Mishel (1986): “The Union Impact on Profits: Evidence from Industry Price-Cost Margin Data," Journal of Labor Economics, 4, 105-133. 
Williamson, O. E. (1975): Markets and Hierarchies: Analysis and Antitrust Implications, New York: The Free Press.

(1991): "Comparative Economic Organization: the Analysis of Discrete Structural Alternatives," Administrative Science Quarterly, 36, 269-96.

Williamson, O. E., M. L. Wachter, AND J. E. HarRis (1975): "Understanding the Employment Relation: the Analysis of Idiosyncratic Exchange," Bell Journal of Economics, 6, 250-278.

Wood, H. G. (1877): A treatise on the law of master and servant, Albany, N.Y.: J.D. Parsons. 


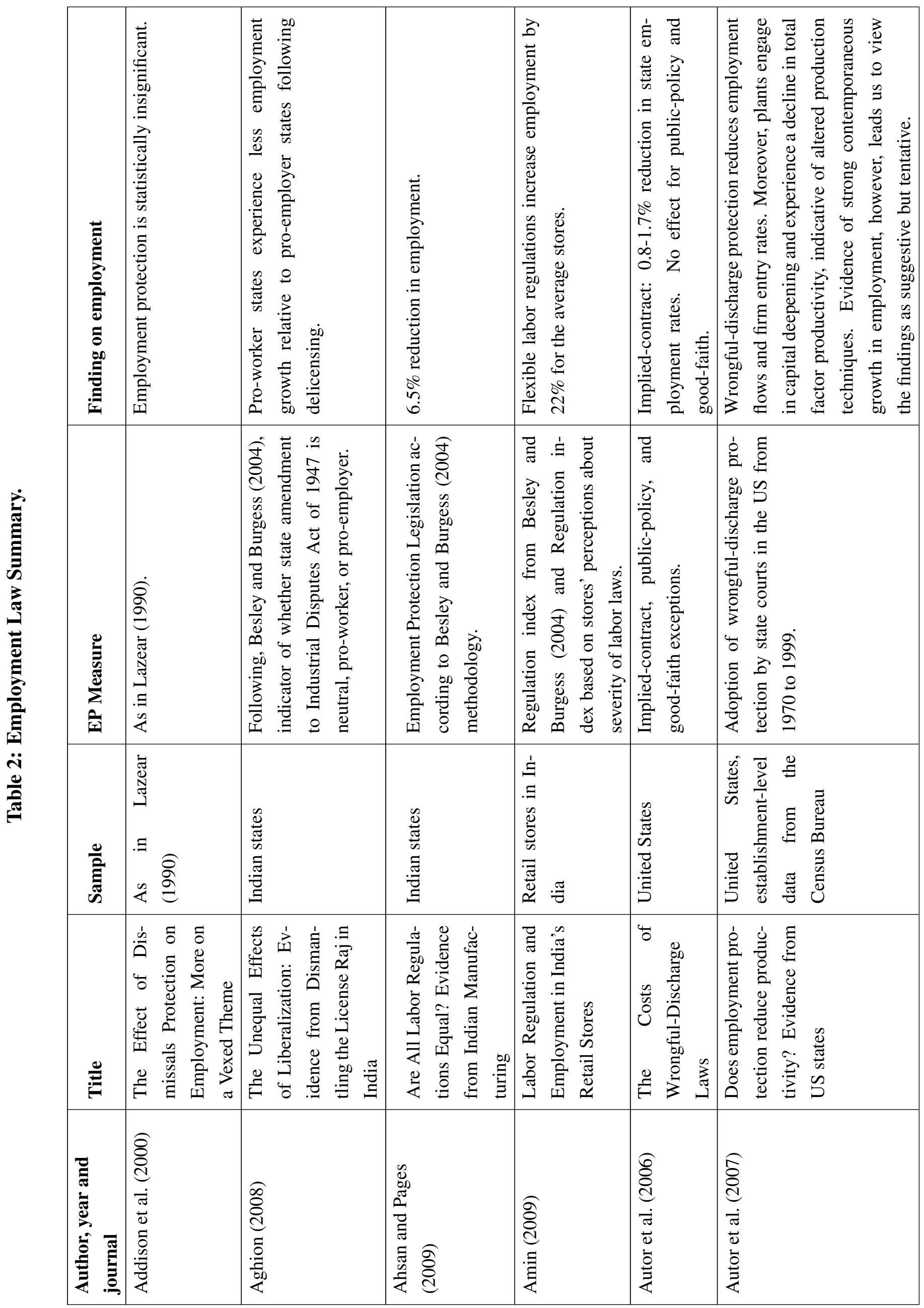




\begin{tabular}{|c|c|c|c|c|}
\hline 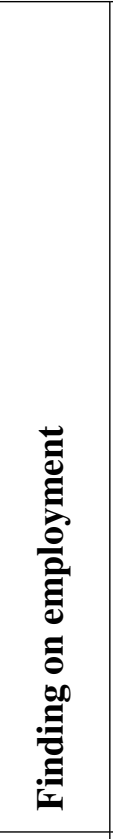 & 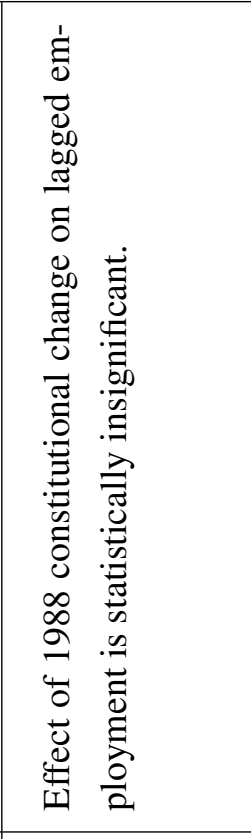 & 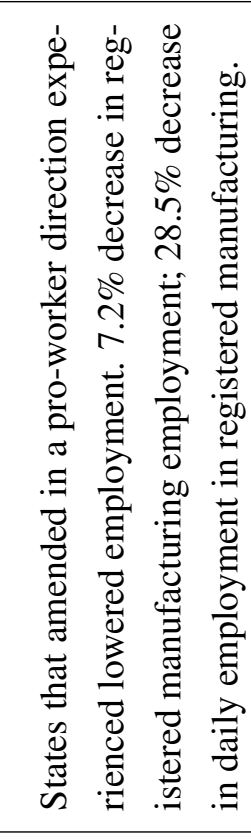 & 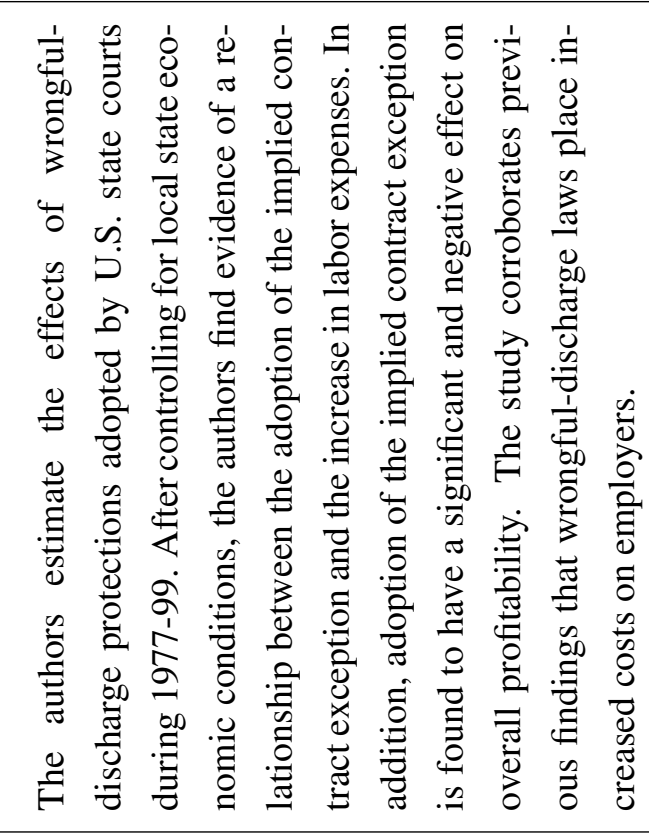 & 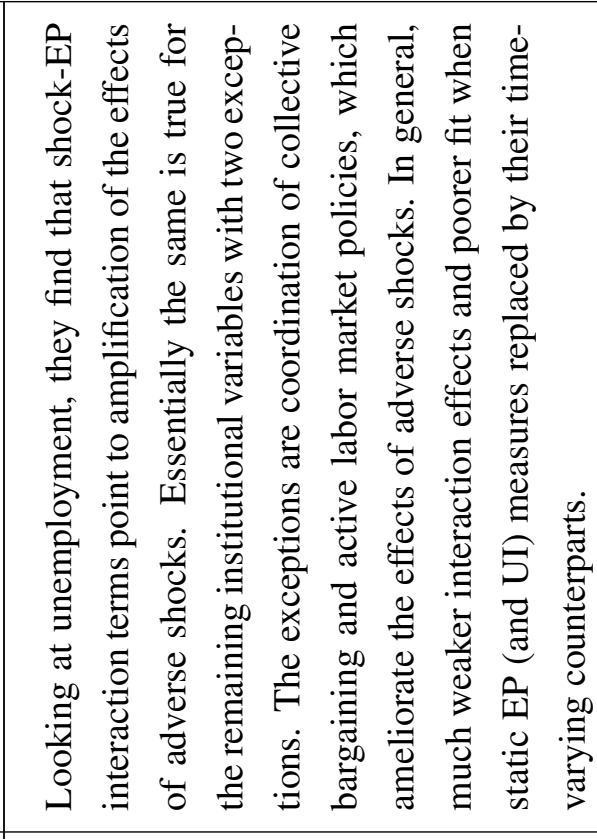 \\
\hline 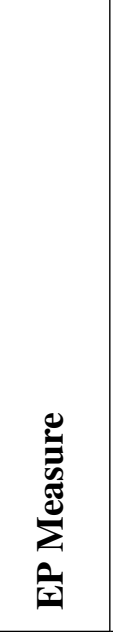 & 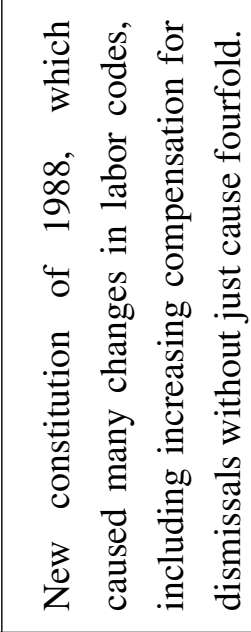 & 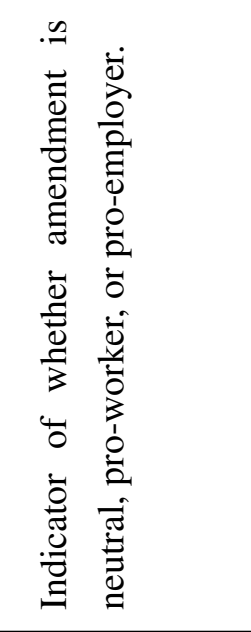 & 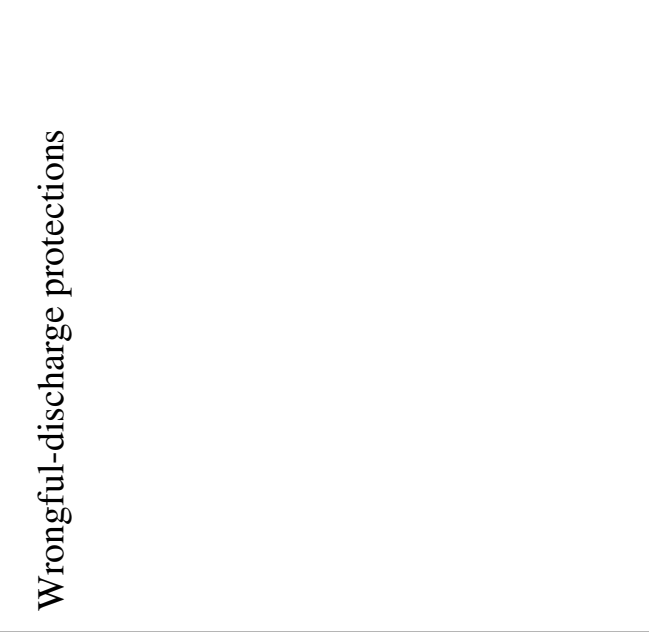 & 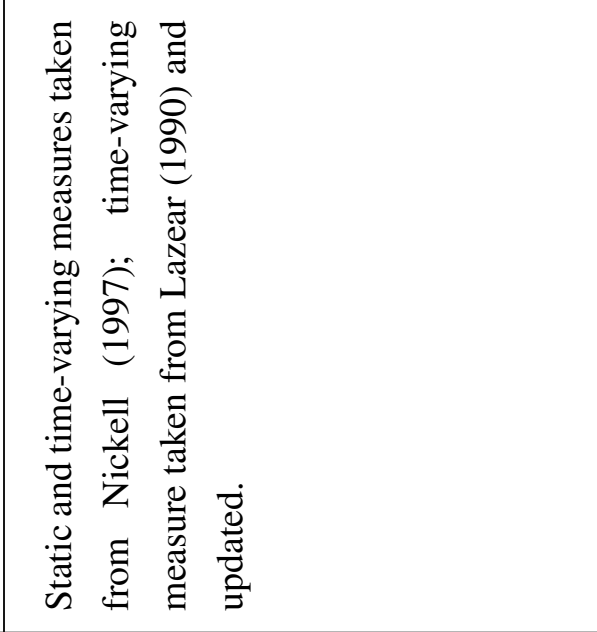 \\
\hline 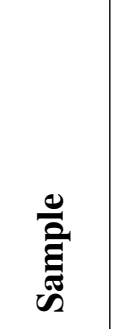 & 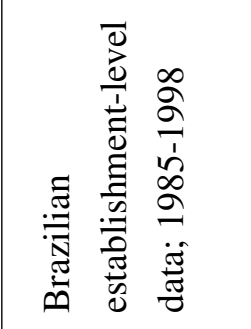 & 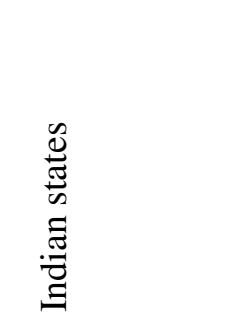 & 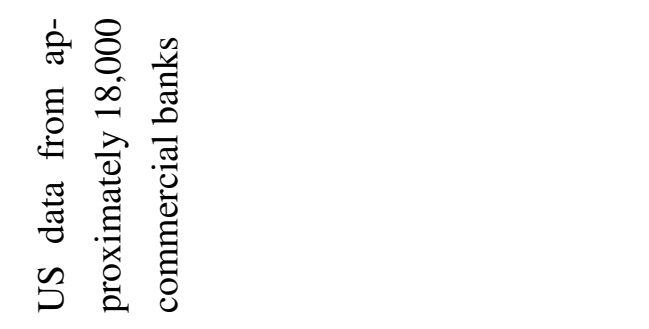 & 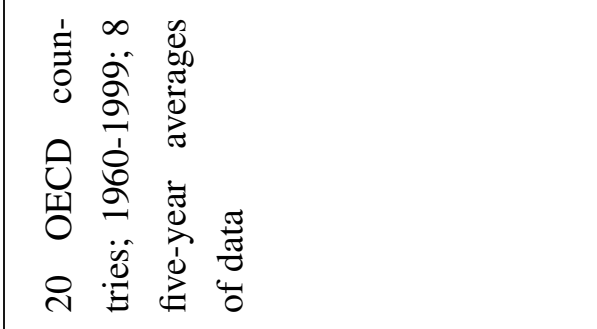 \\
\hline 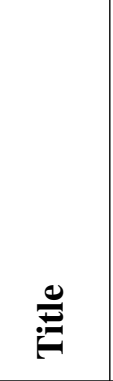 & 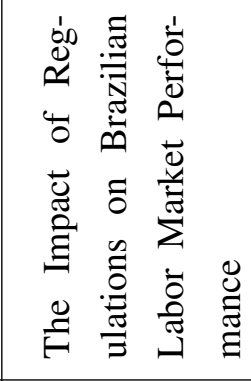 & 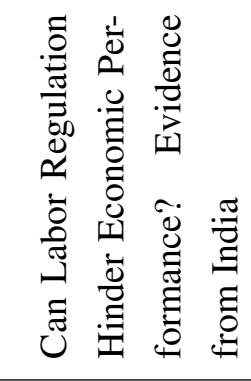 & 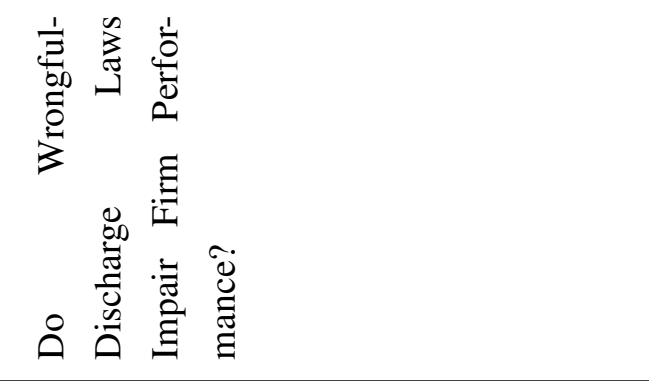 & 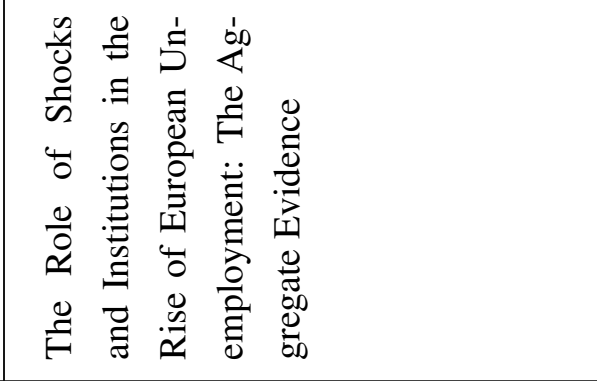 \\
\hline 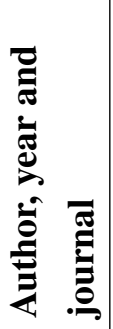 & 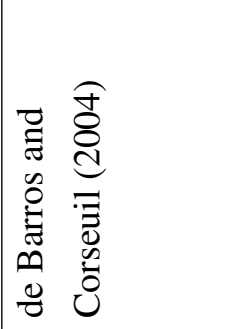 & 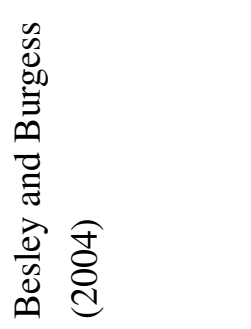 & 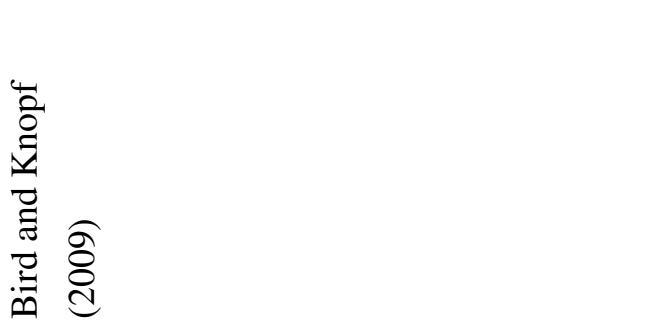 & 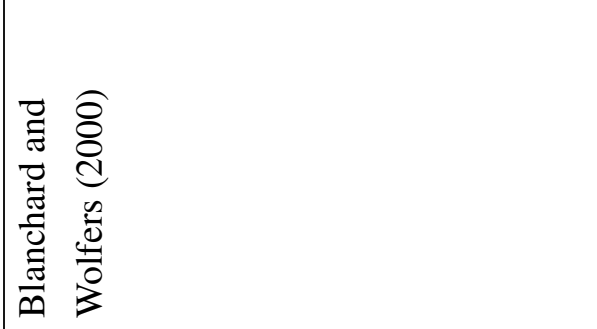 \\
\hline
\end{tabular}




\begin{tabular}{|c|c|c|c|}
\hline 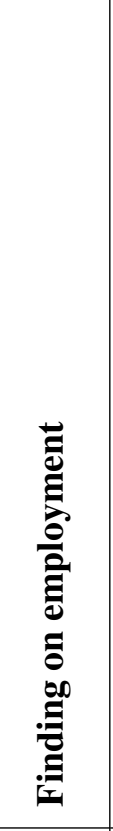 & 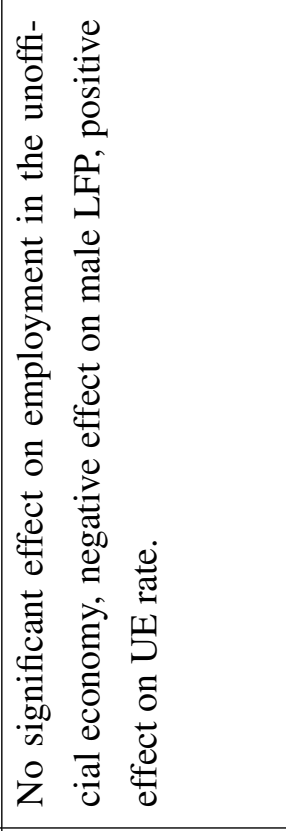 & 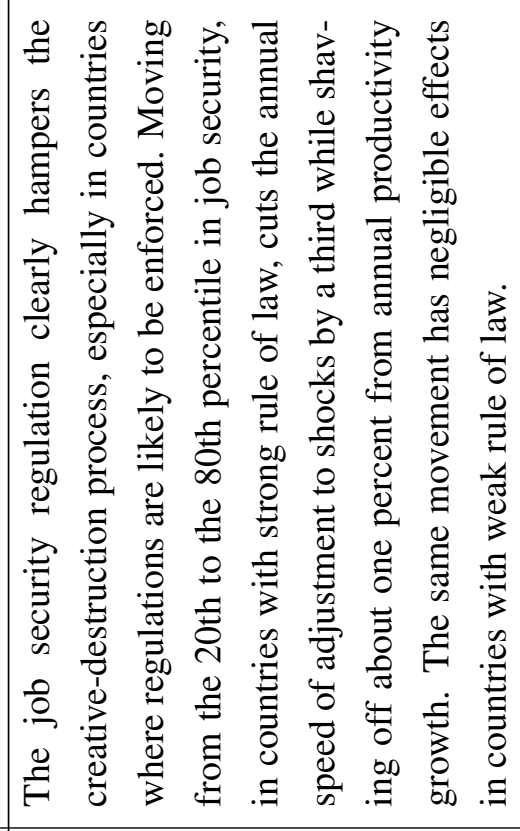 & 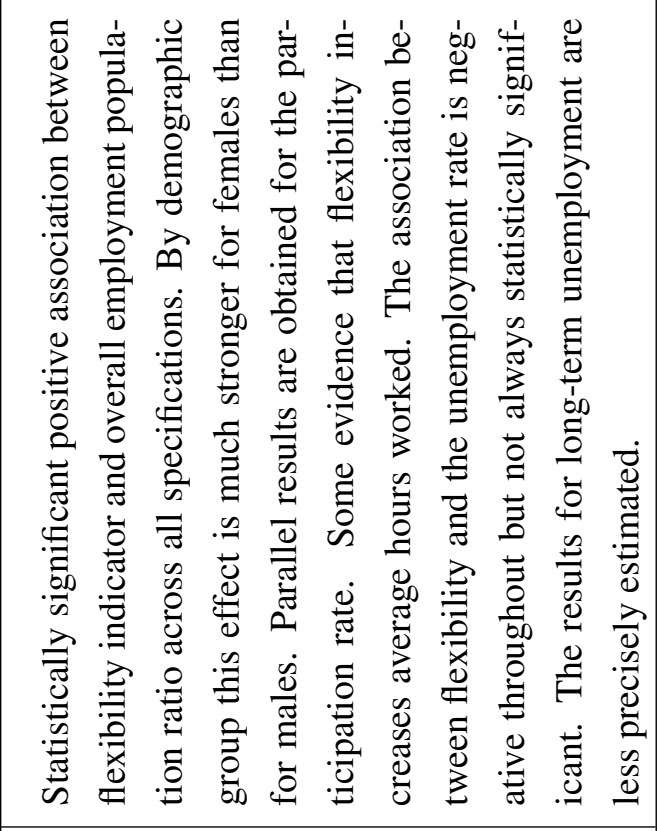 \\
\hline 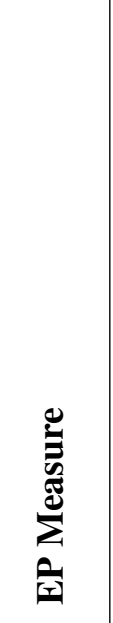 & 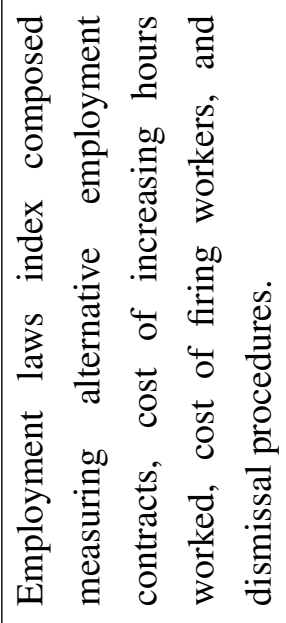 & 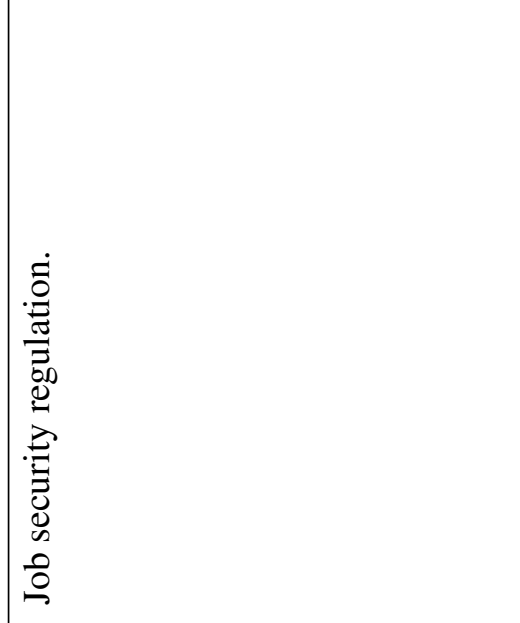 & 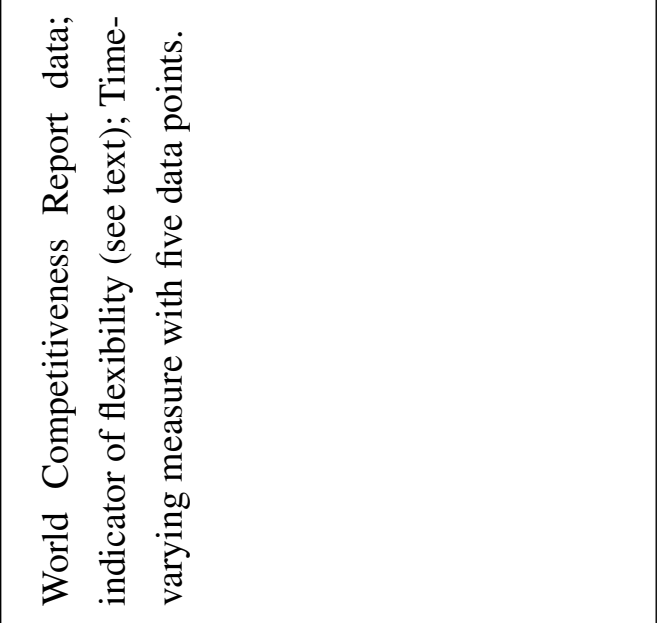 \\
\hline 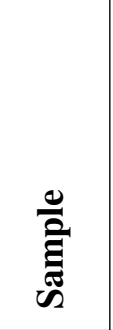 & & 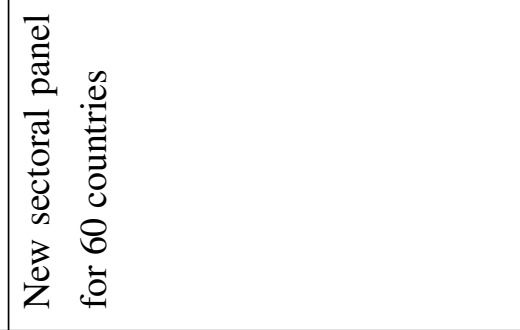 & 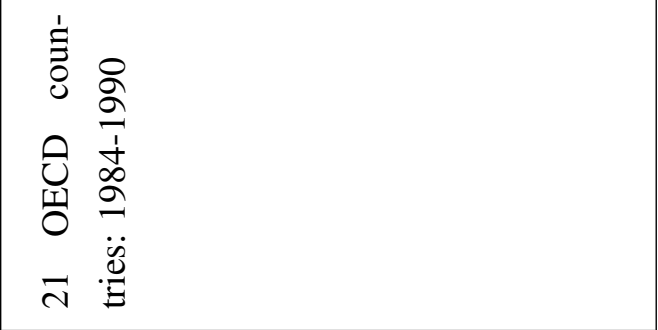 \\
\hline$\stackrel{\varrho}{E}$ & 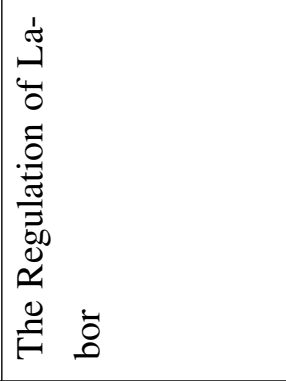 & 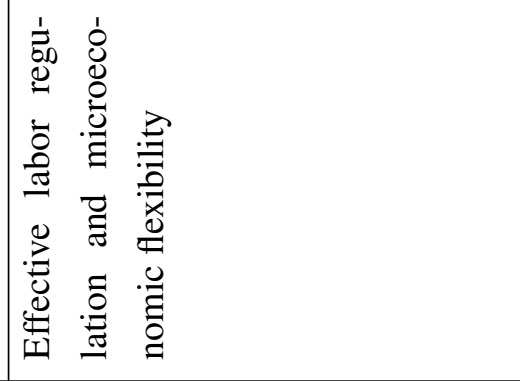 & 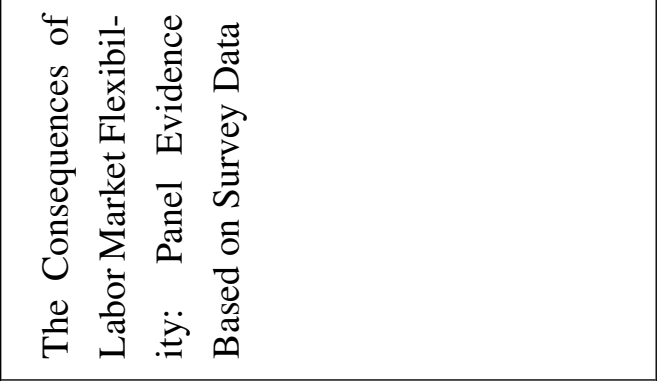 \\
\hline 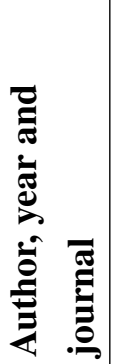 & 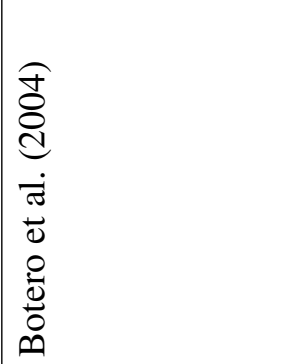 & 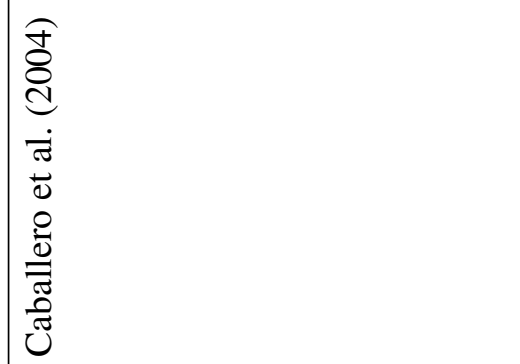 & 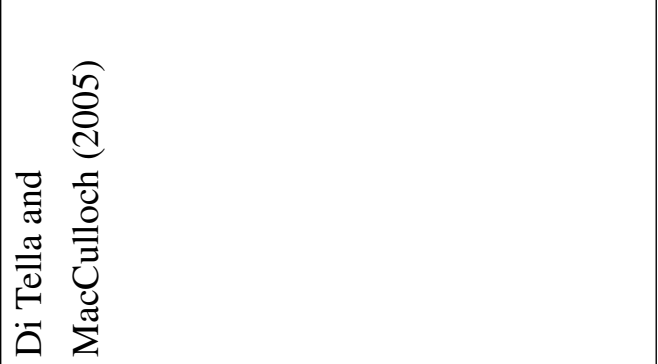 \\
\hline
\end{tabular}




\begin{tabular}{|c|c|c|c|c|c|}
\hline 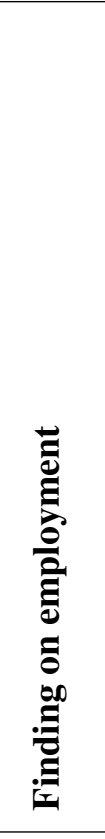 & 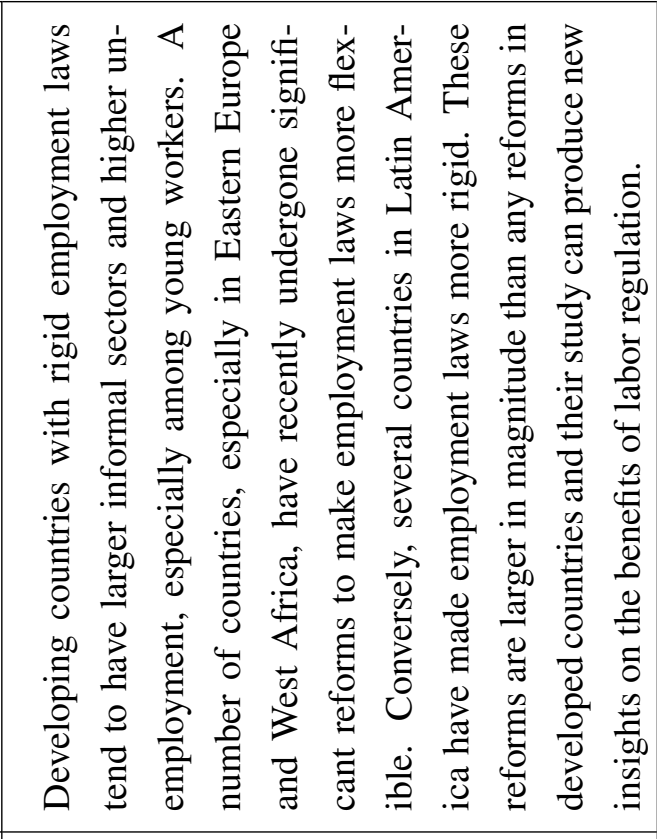 & 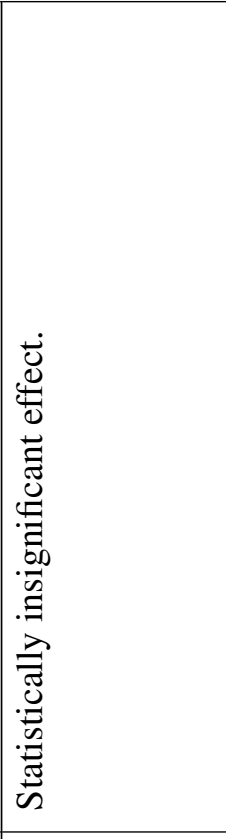 & 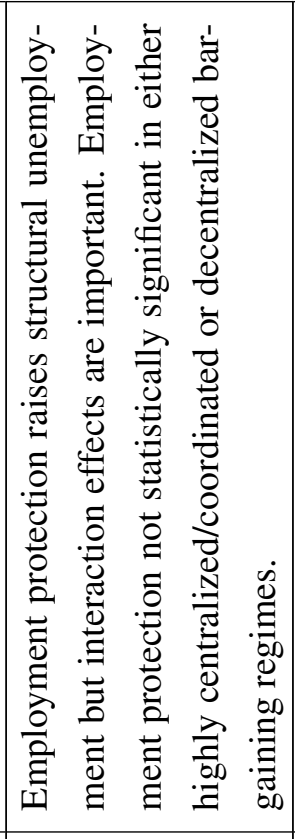 & 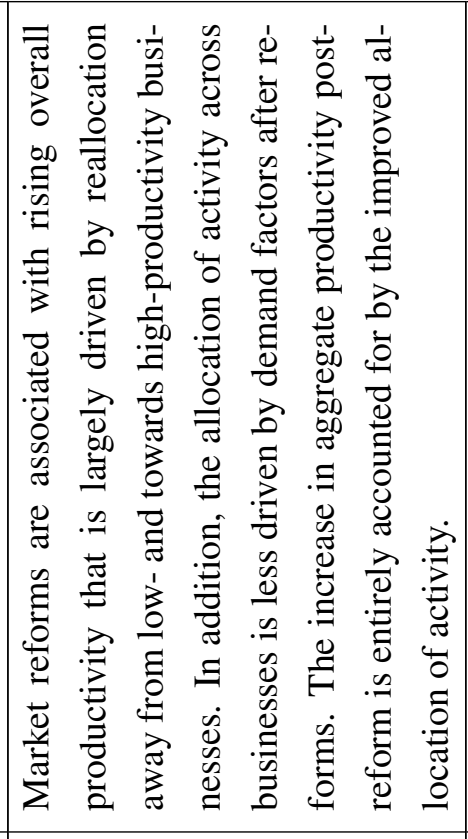 & 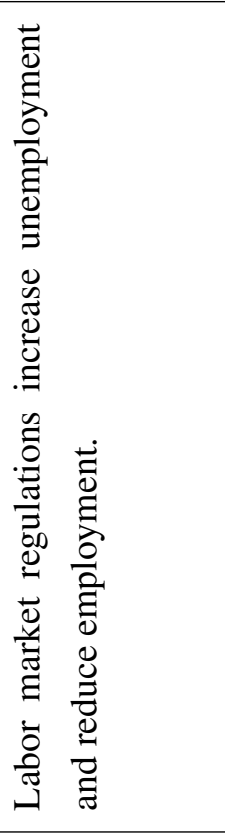 \\
\hline 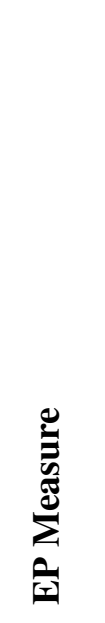 & 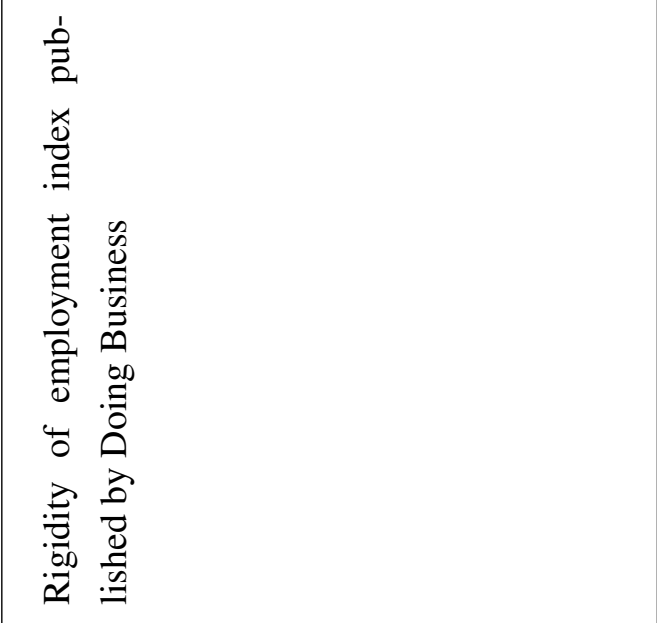 & 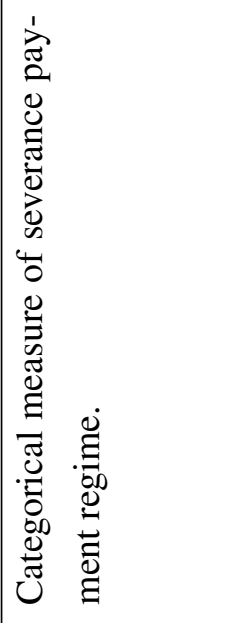 & 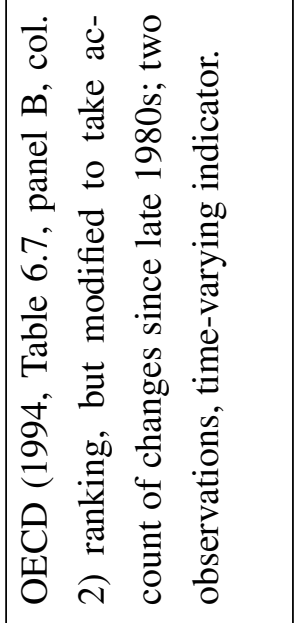 & 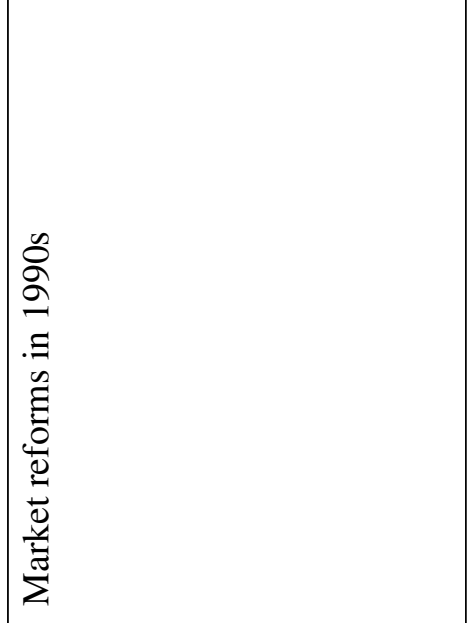 & 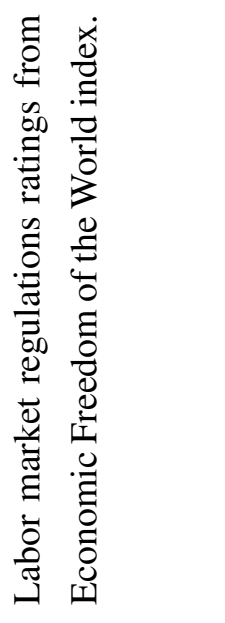 \\
\hline 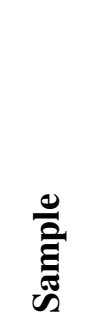 & 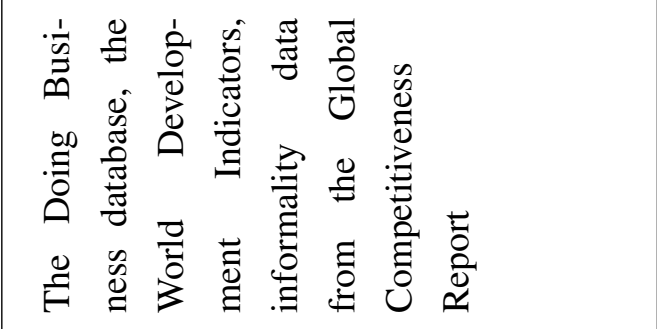 & 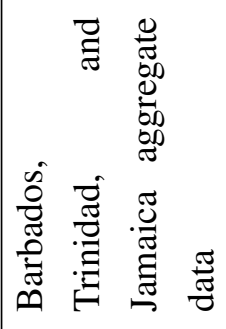 & 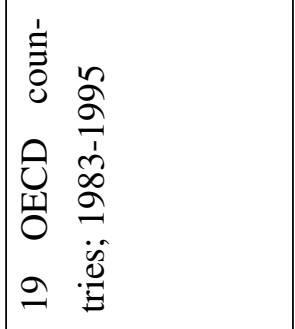 & 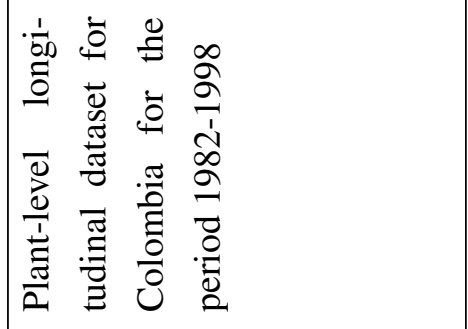 & 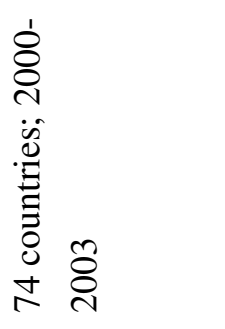 \\
\hline$\stackrel{\varrho}{\Xi}$ & 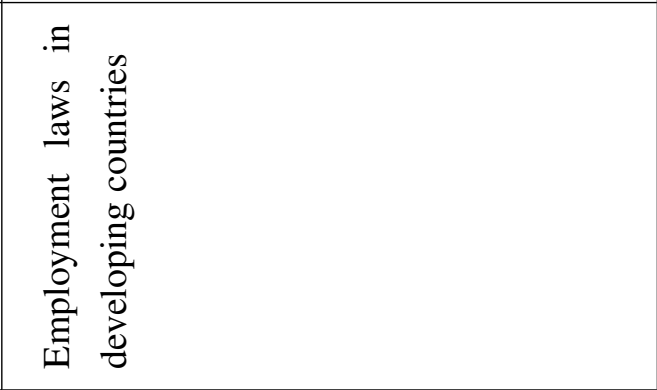 & 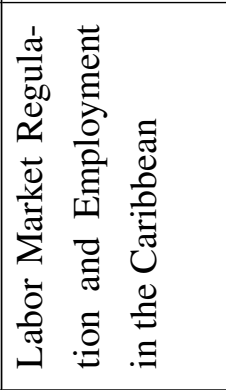 & 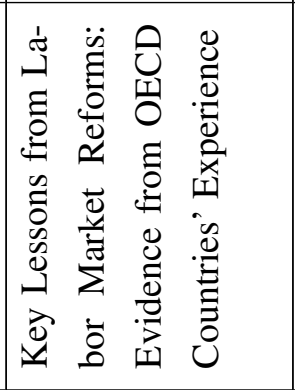 & 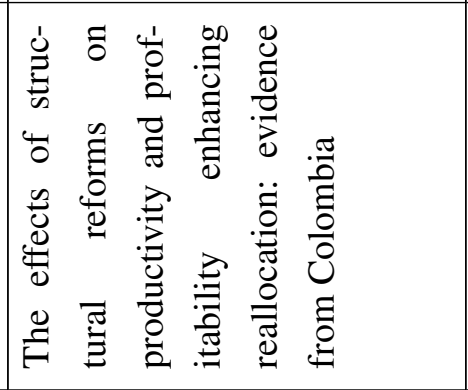 & 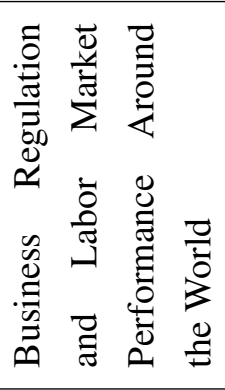 \\
\hline 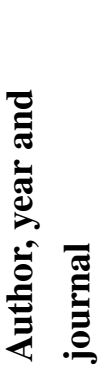 & 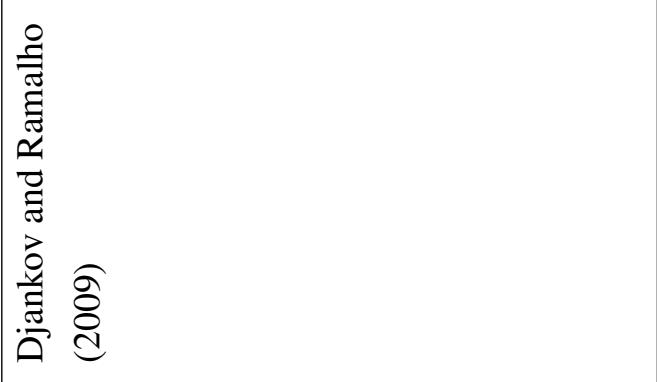 & 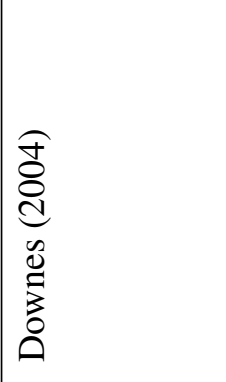 & 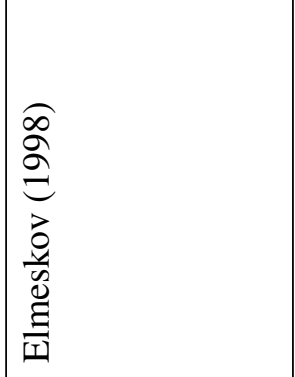 & 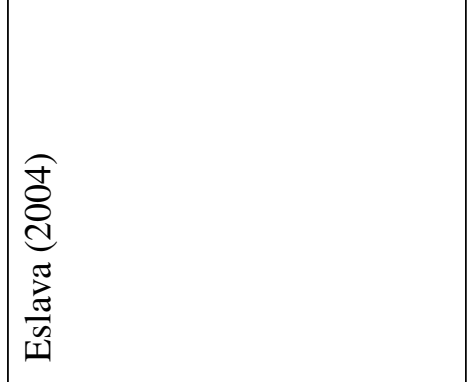 & 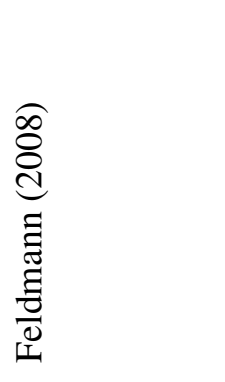 \\
\hline
\end{tabular}




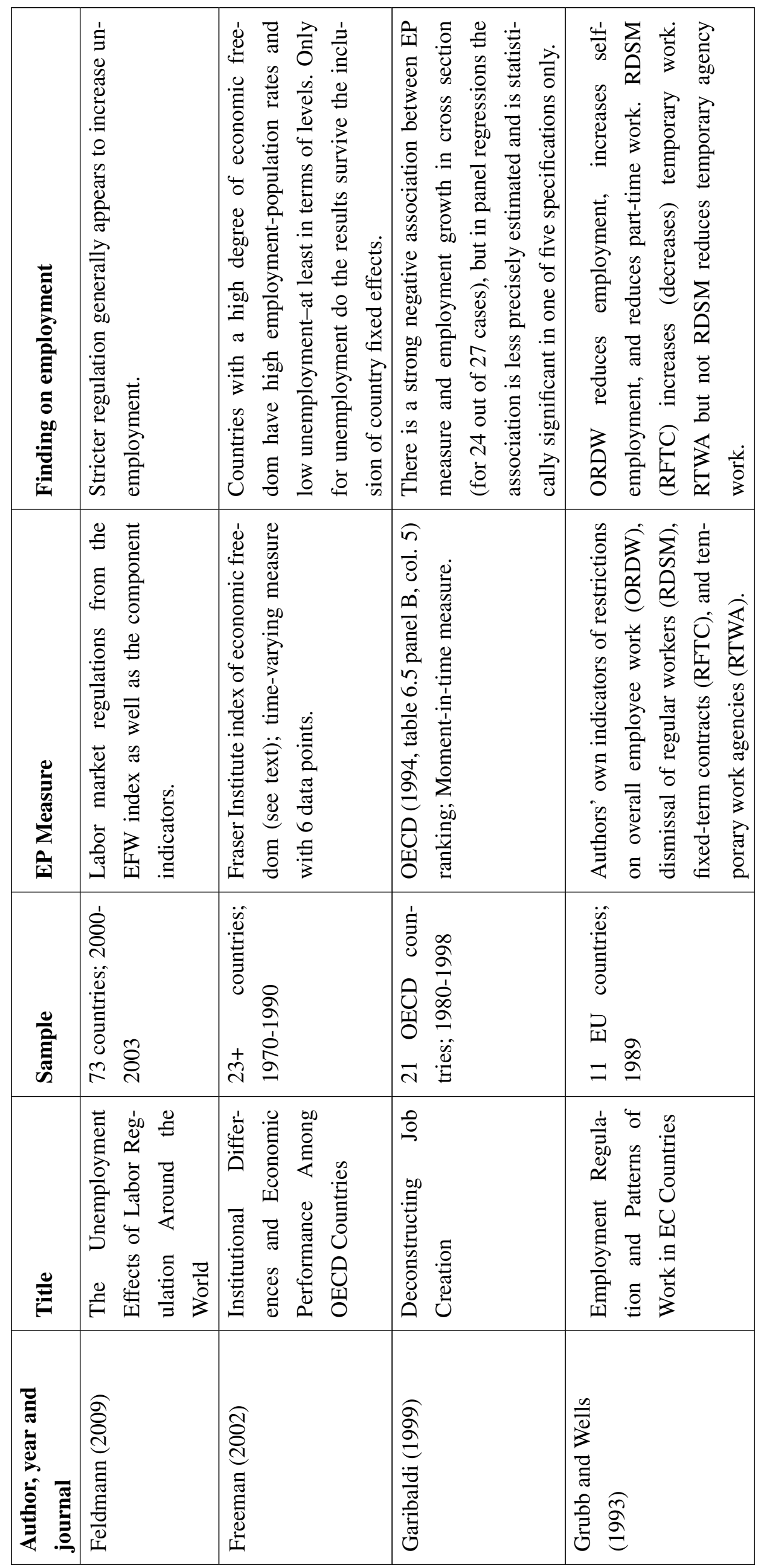




\begin{tabular}{|c|c|c|c|}
\hline 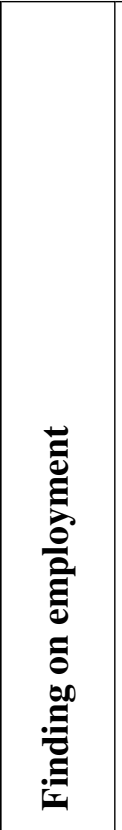 & 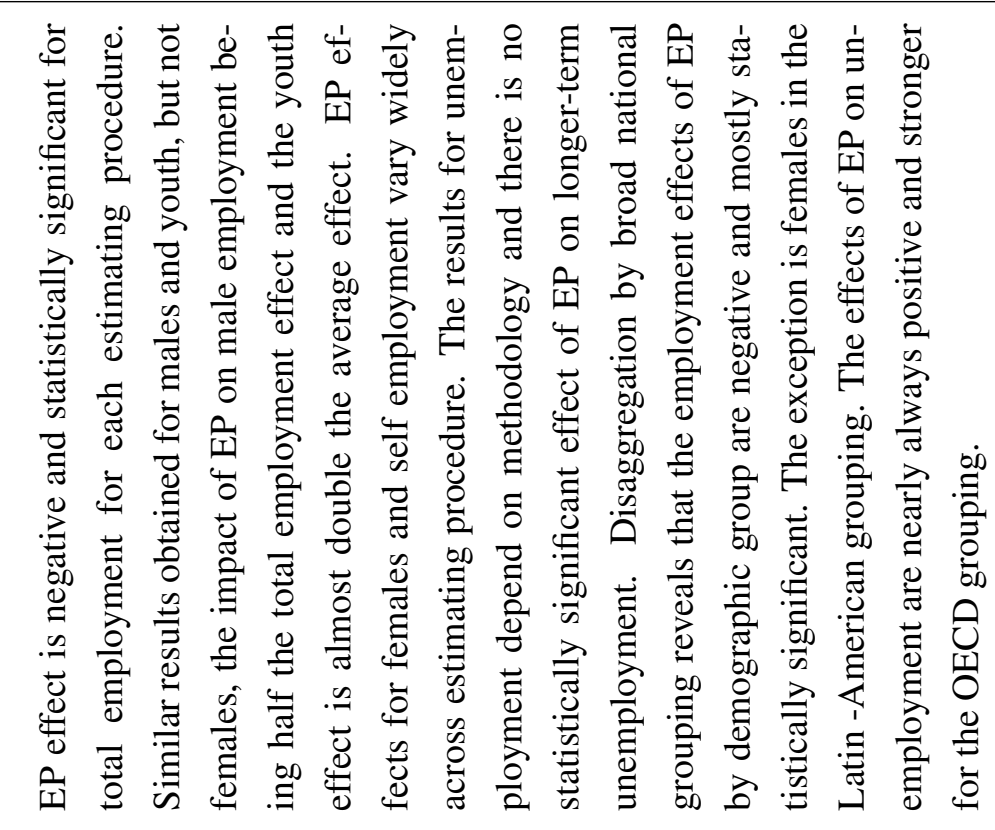 & 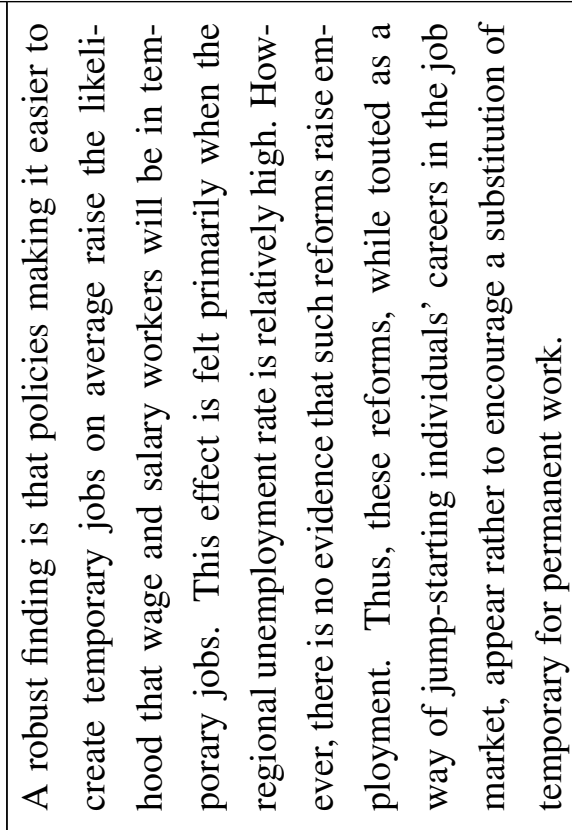 & 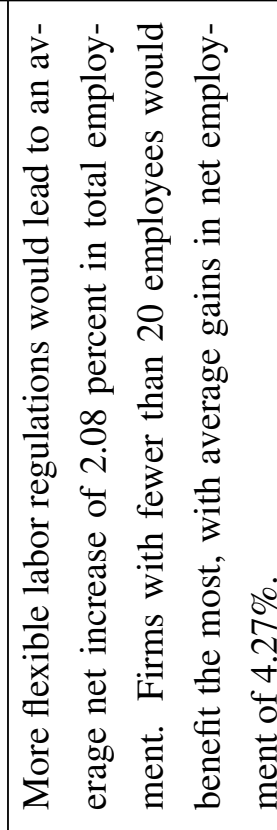 \\
\hline 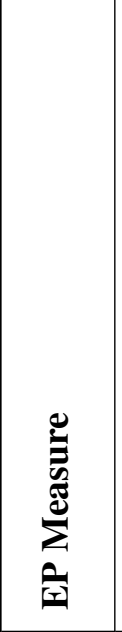 & 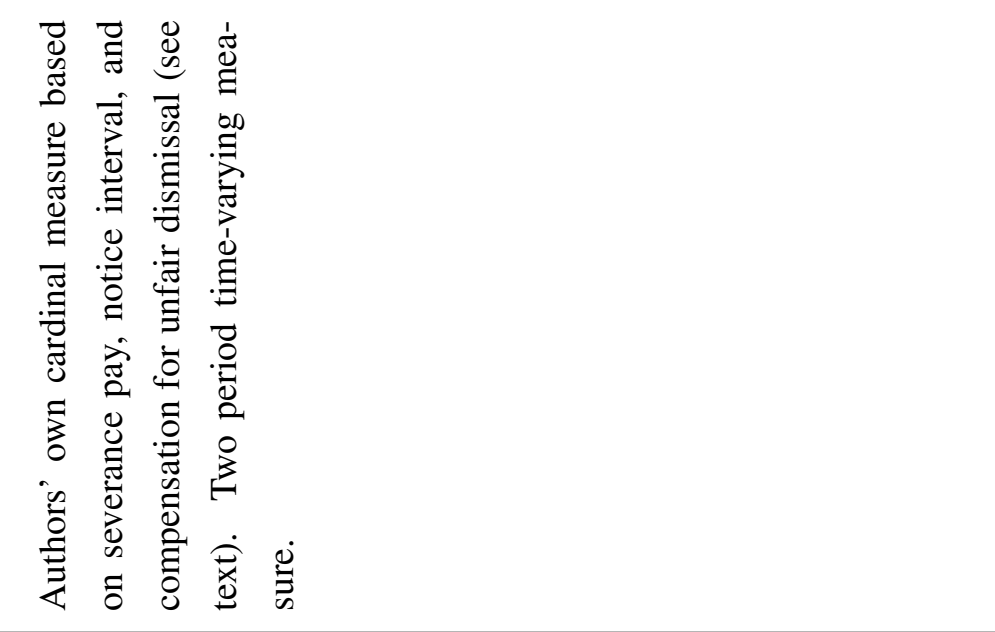 & 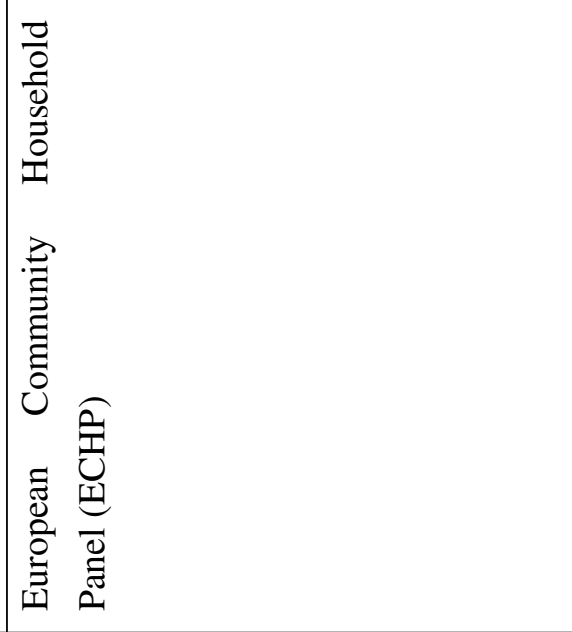 & 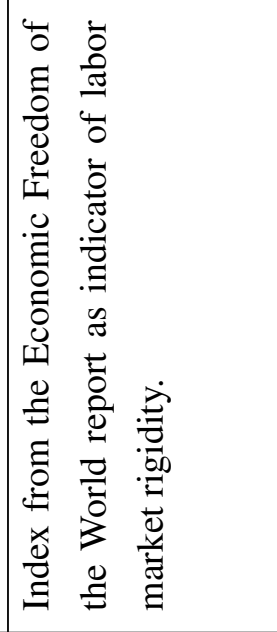 \\
\hline 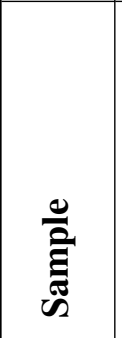 & 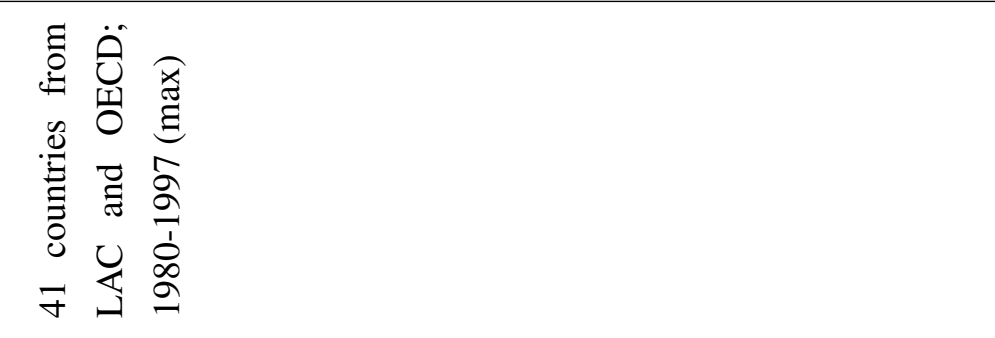 & 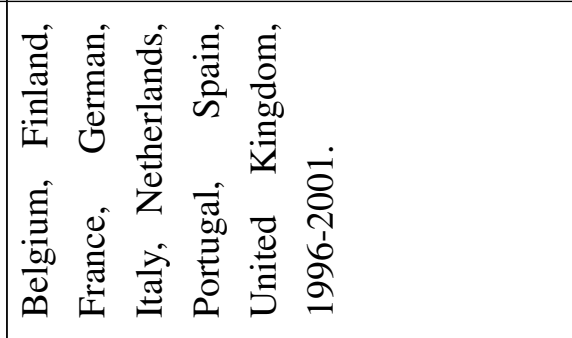 & 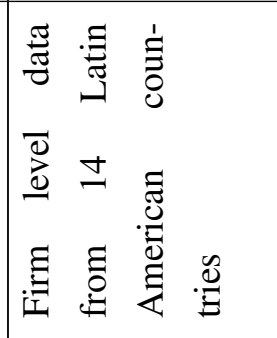 \\
\hline$\stackrel{\varrho}{\Xi}$ & 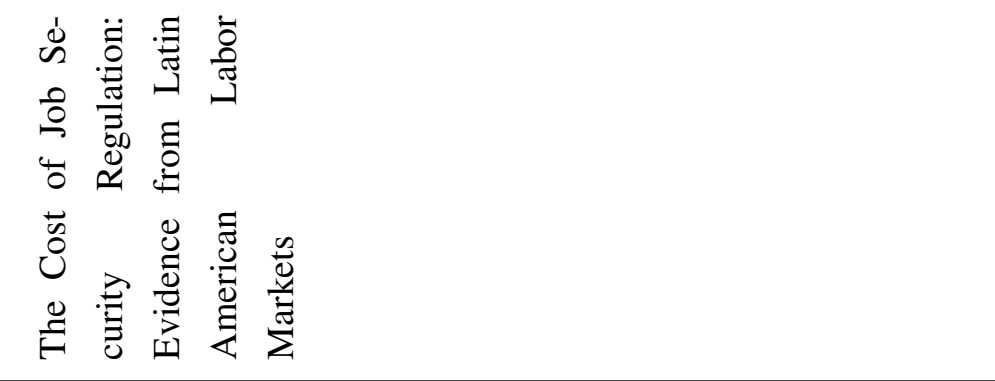 & 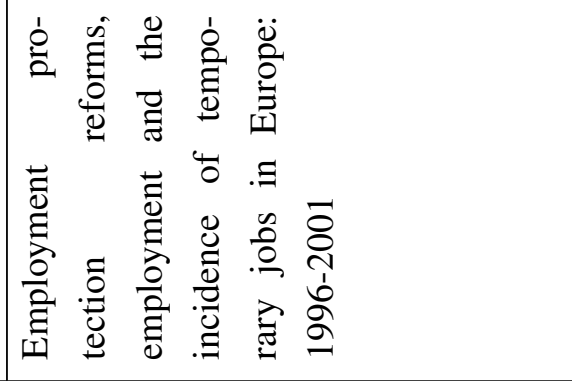 & 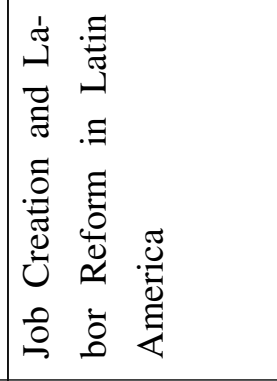 \\
\hline 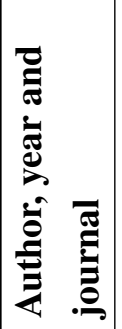 & 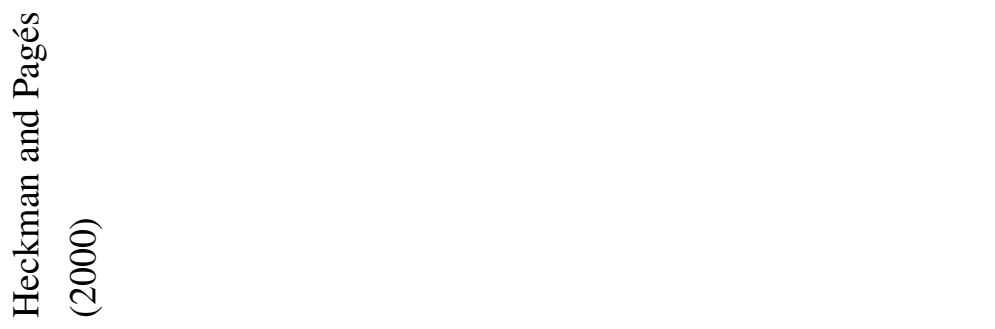 & 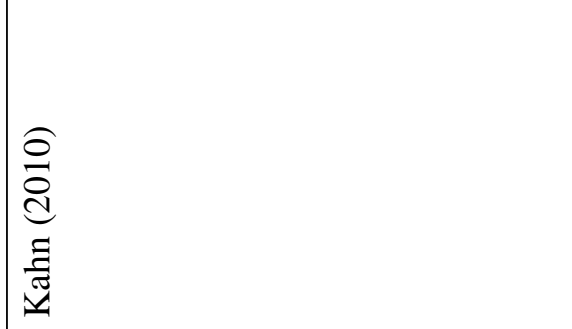 & 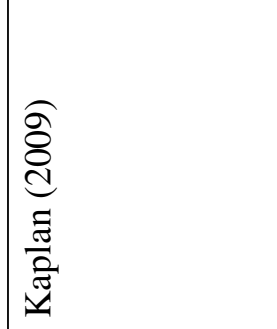 \\
\hline
\end{tabular}




\begin{tabular}{|c|c|c|c|c|}
\hline 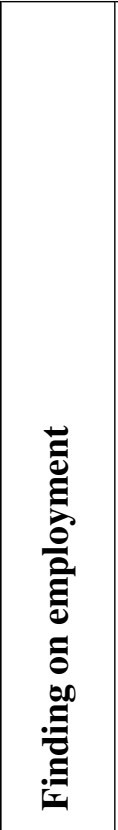 & 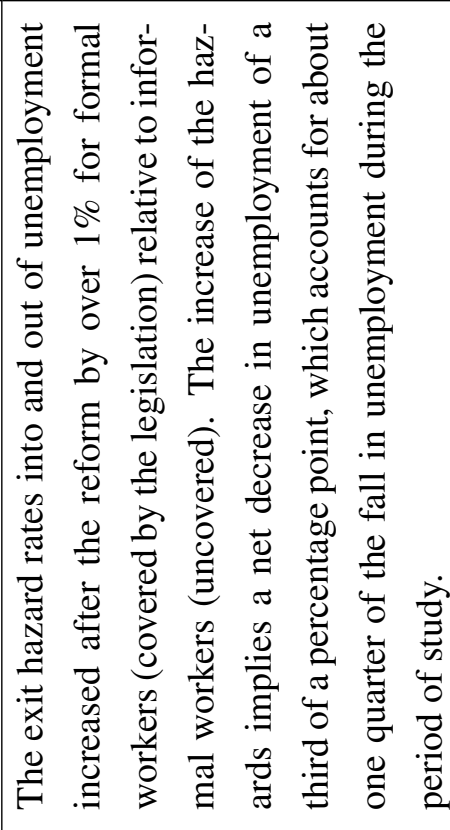 & 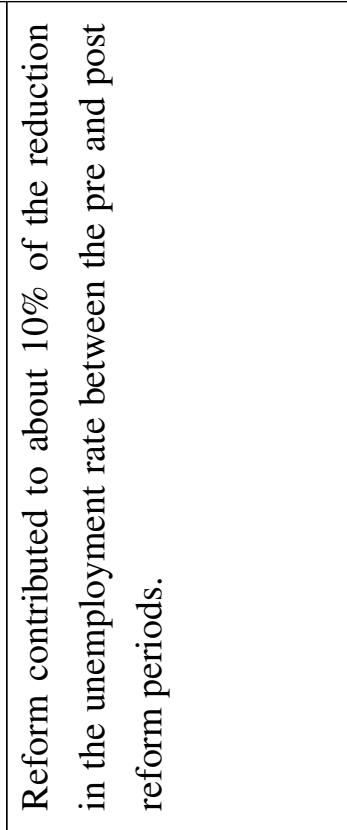 & 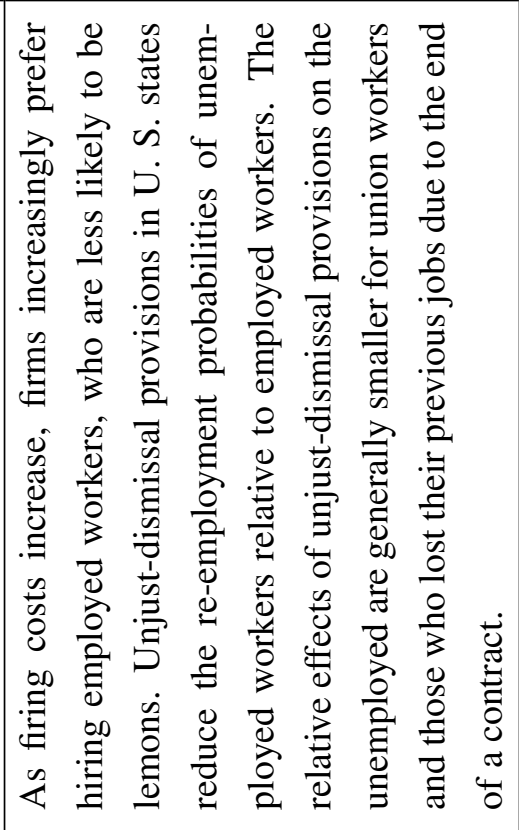 & 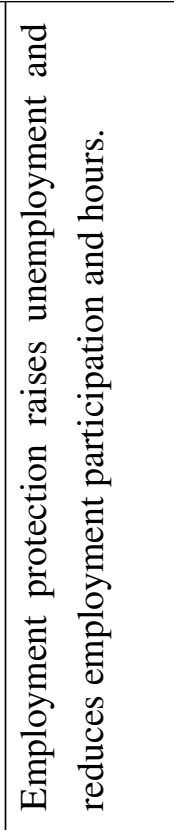 \\
\hline 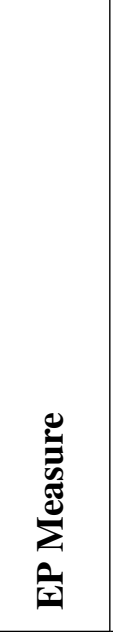 & 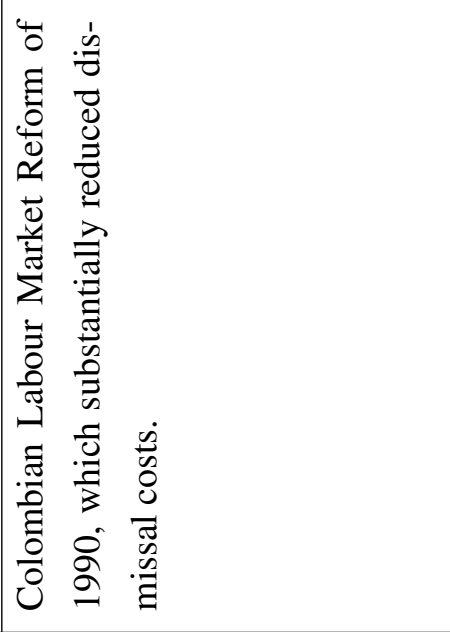 & 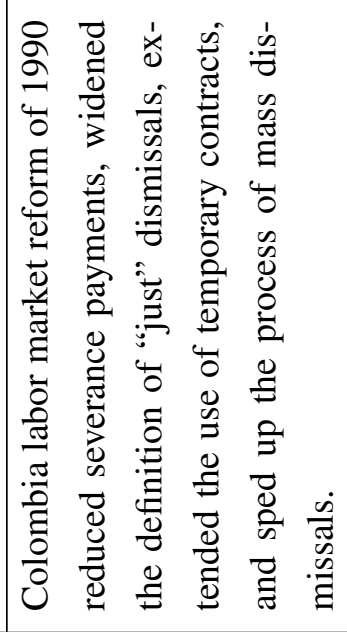 & 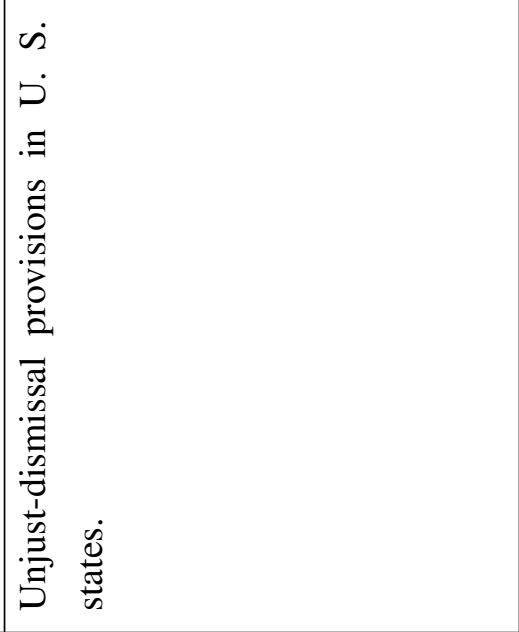 & 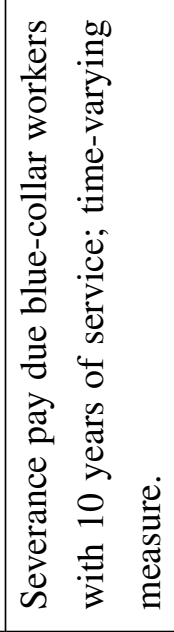 \\
\hline 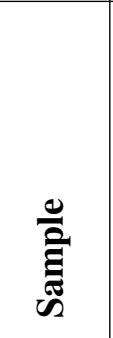 & 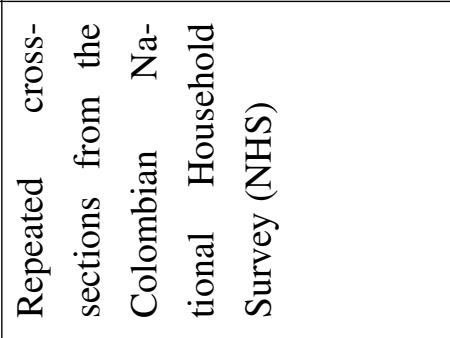 & 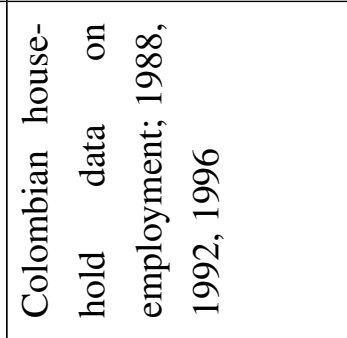 & 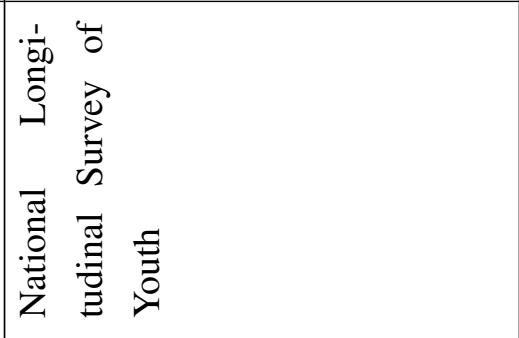 & 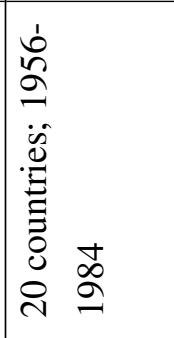 \\
\hline$\stackrel{\varrho}{\Xi}$ & 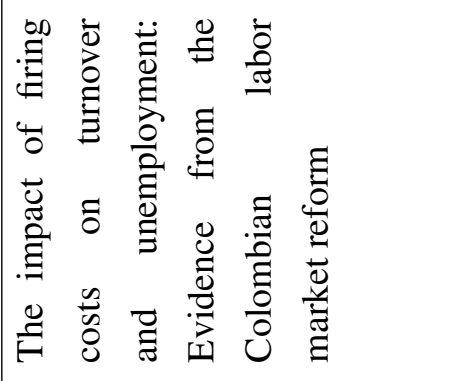 & 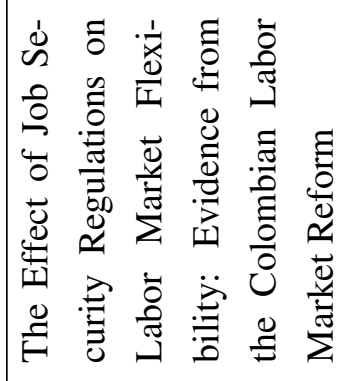 & 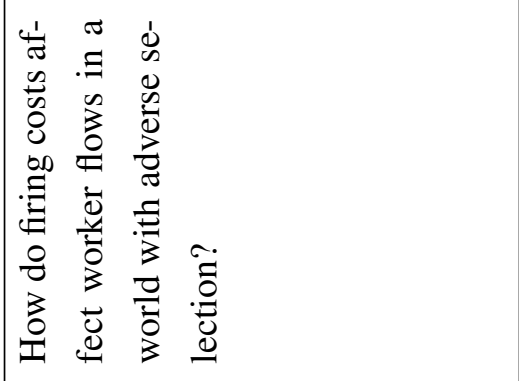 & 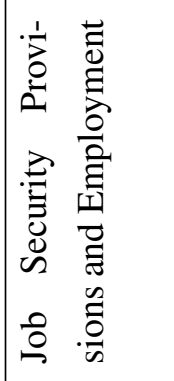 \\
\hline 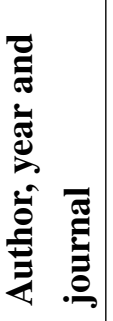 & 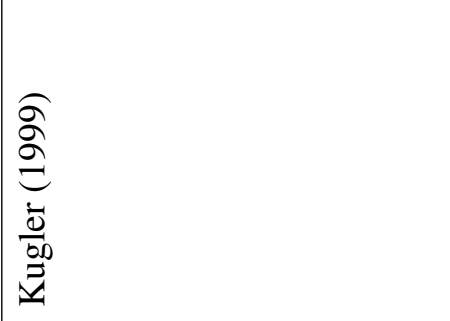 & 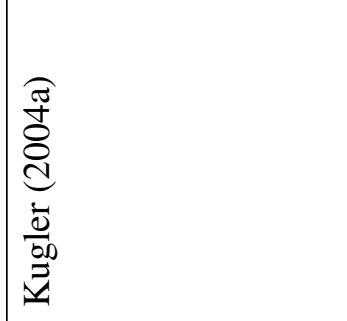 & 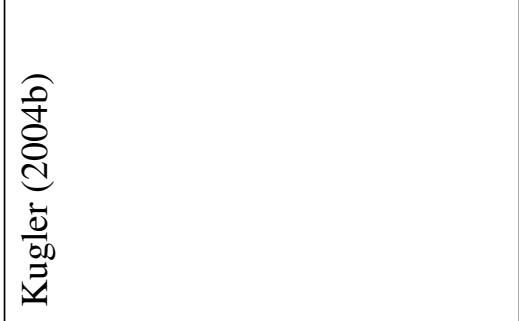 & 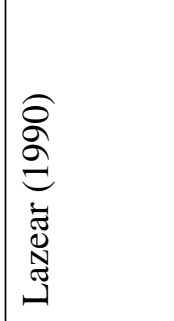 \\
\hline
\end{tabular}




\begin{tabular}{|c|c|c|c|}
\hline 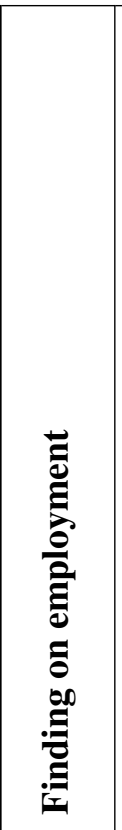 & 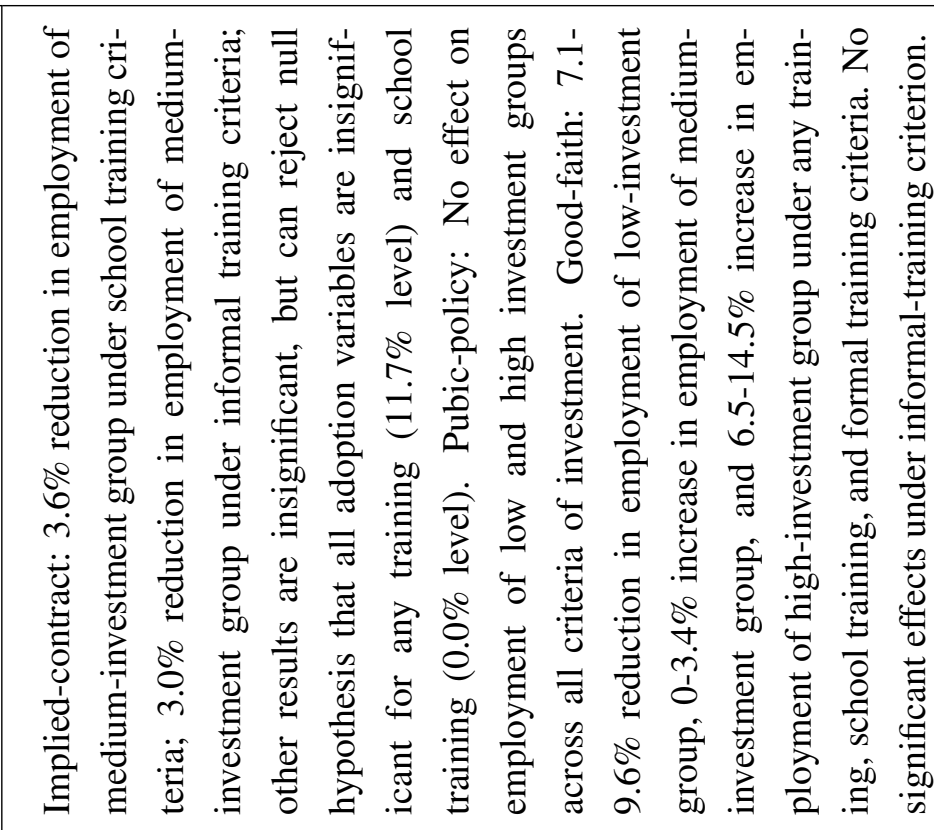 & 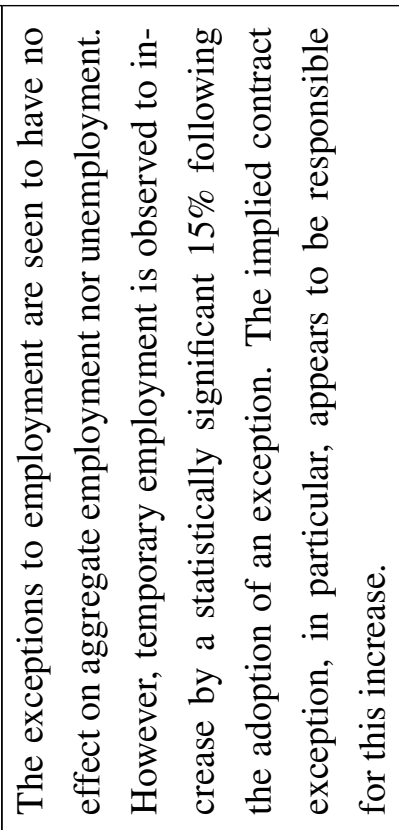 & 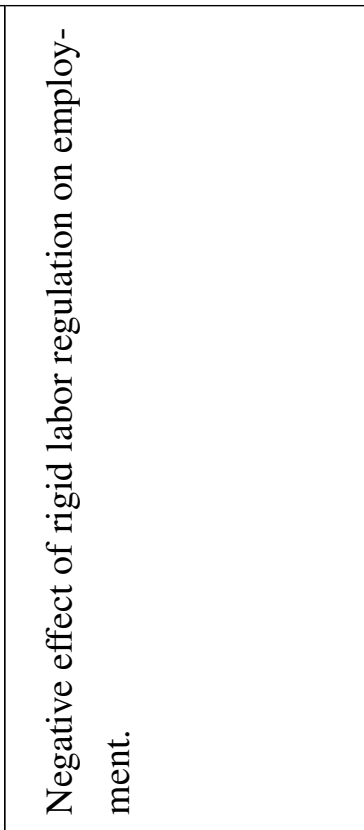 \\
\hline 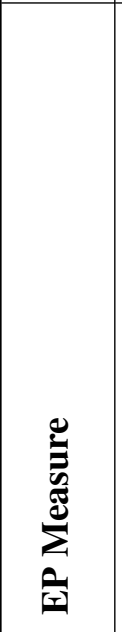 & 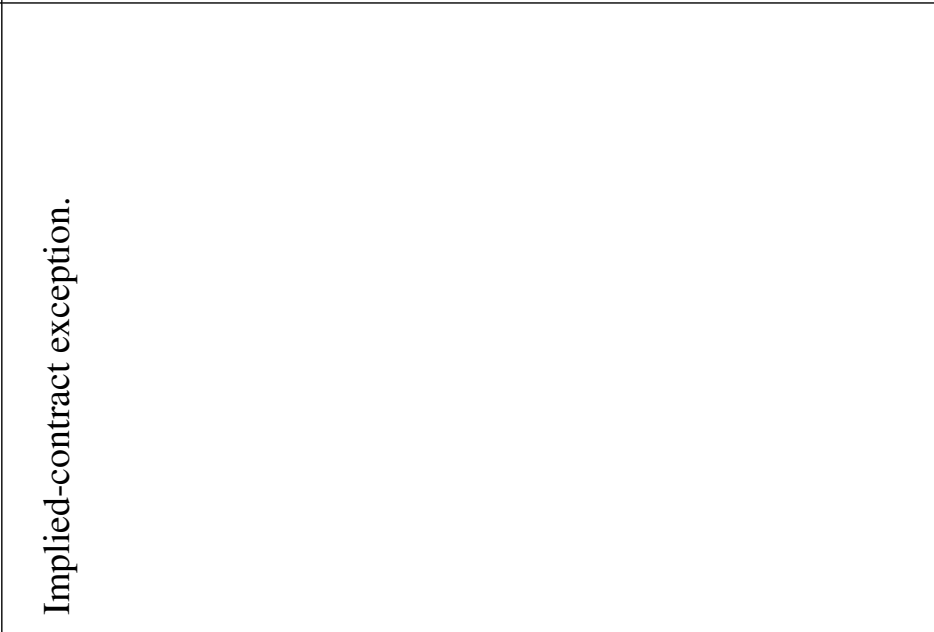 & 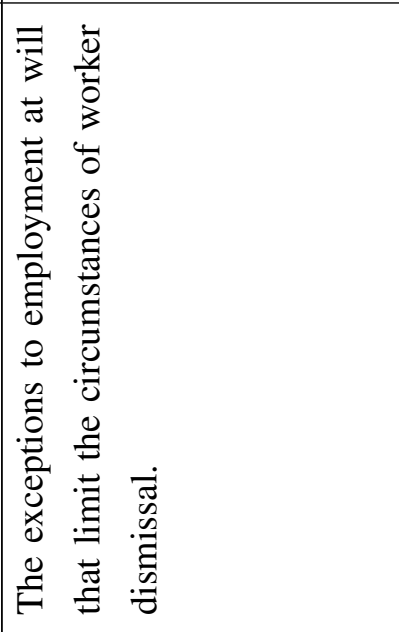 & 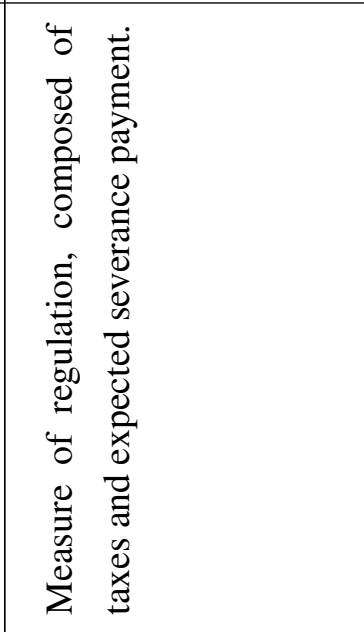 \\
\hline 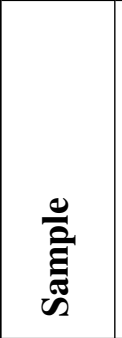 & 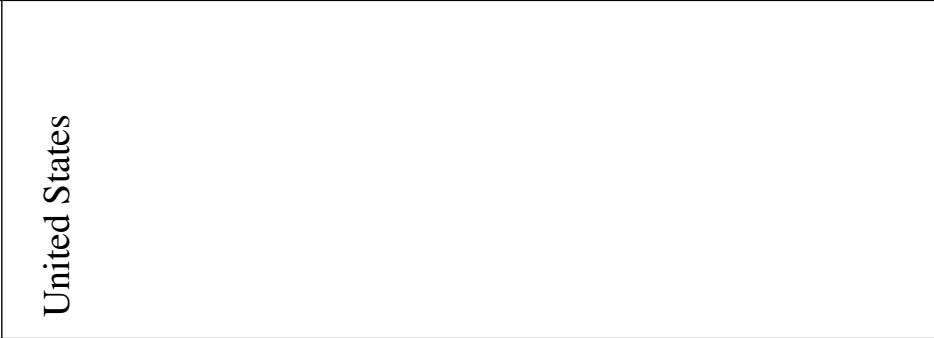 & 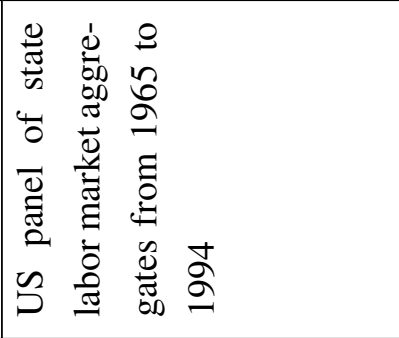 & 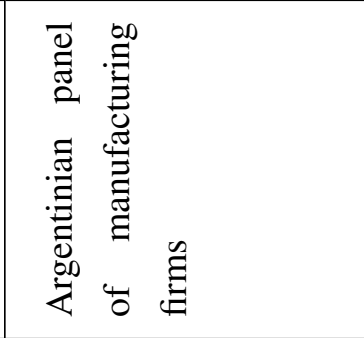 \\
\hline$\stackrel{\varrho}{\Xi}$ & 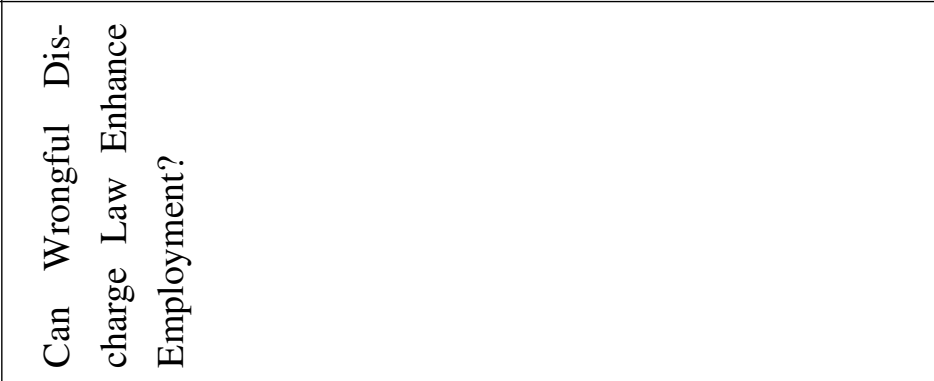 & 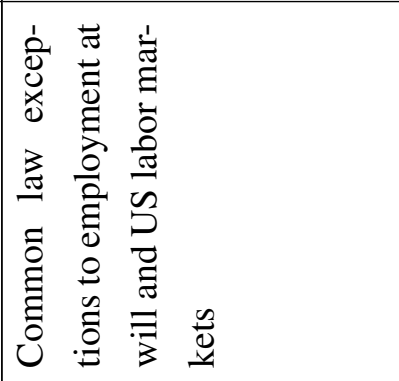 & 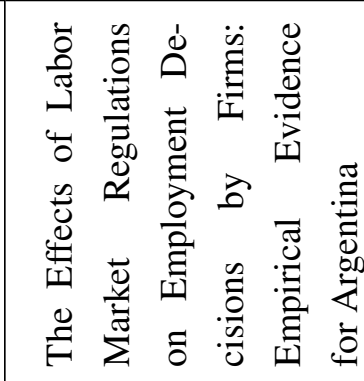 \\
\hline 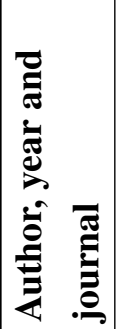 & 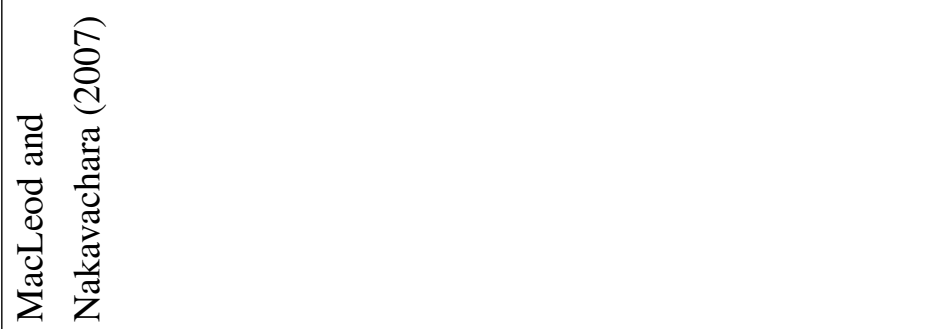 & 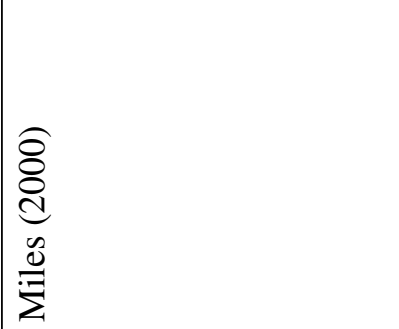 & 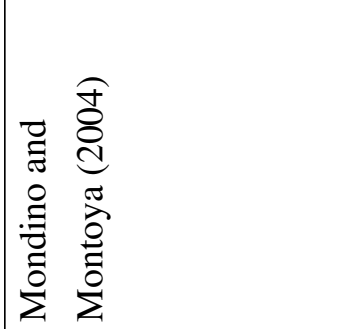 \\
\hline
\end{tabular}




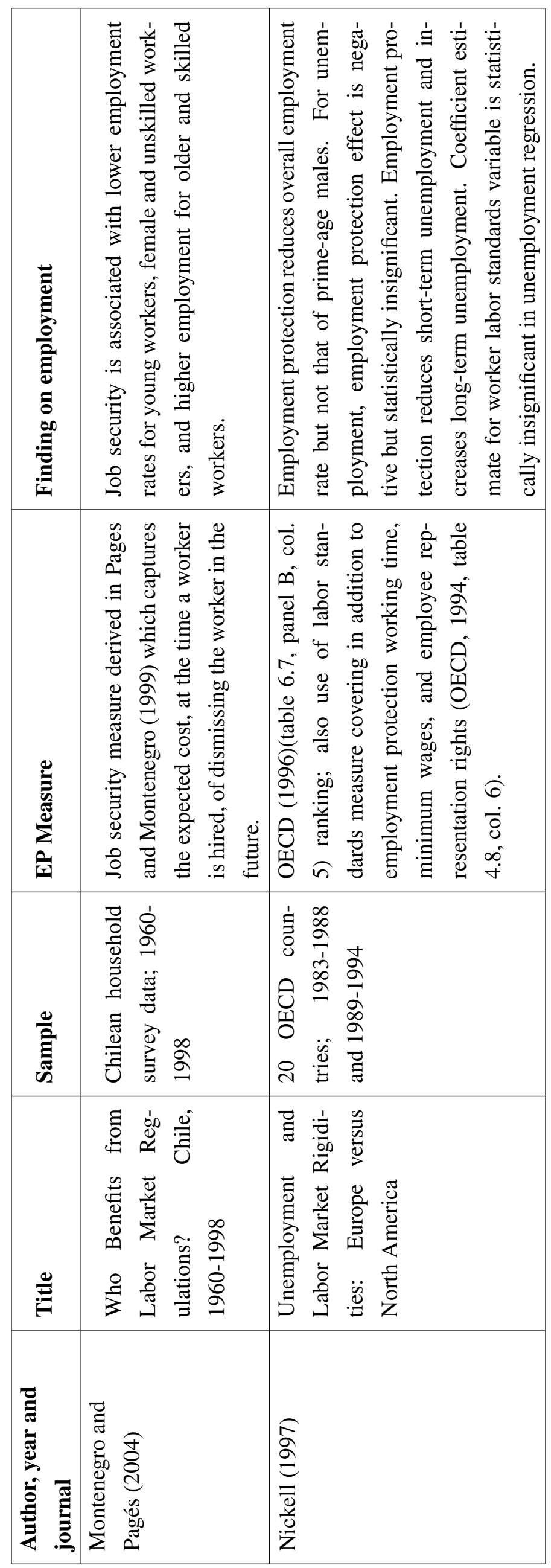




\begin{tabular}{|c|c|c|}
\hline 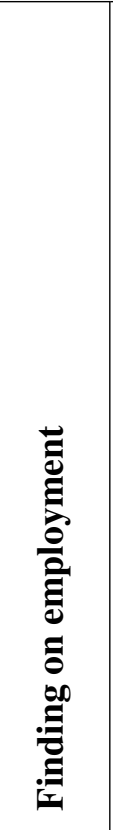 & 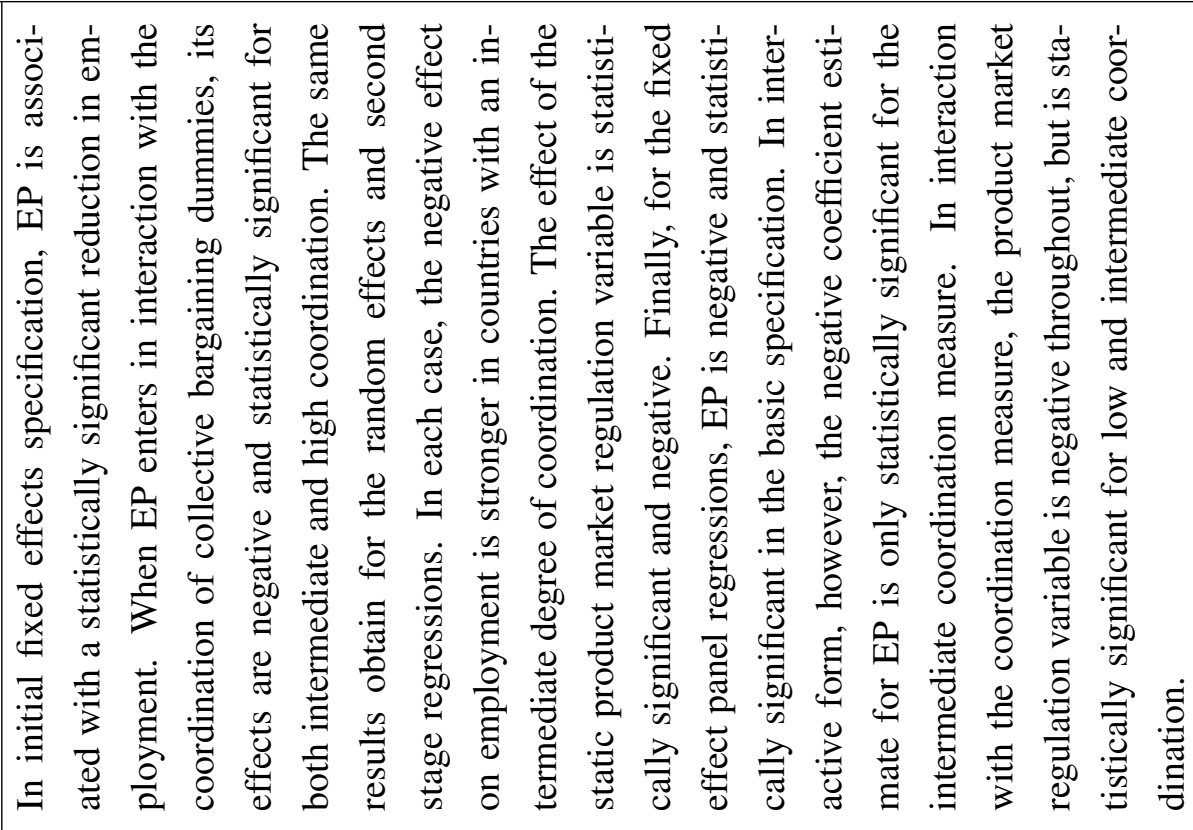 & 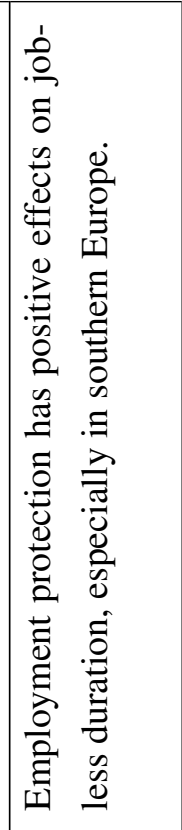 \\
\hline 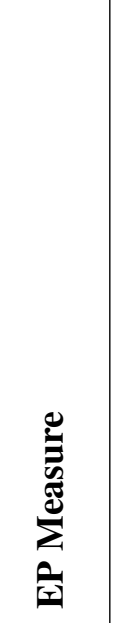 & 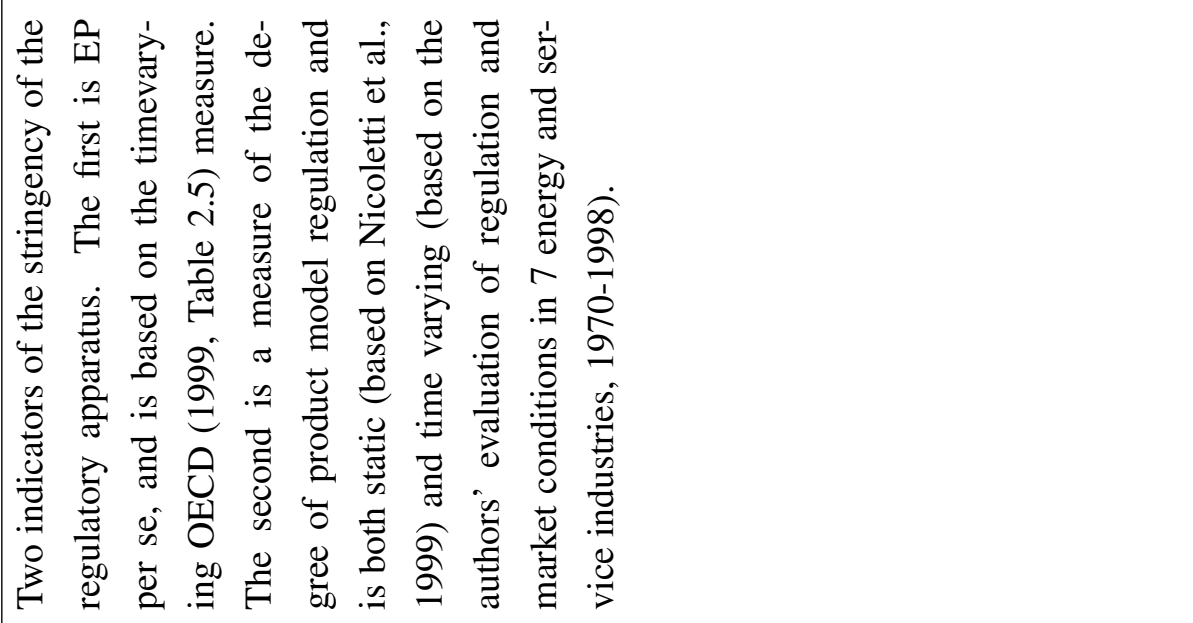 & 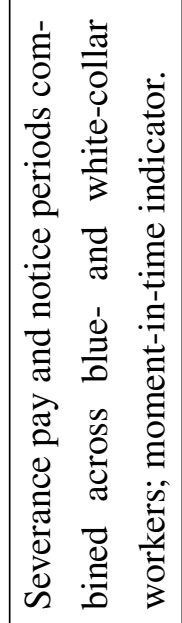 \\
\hline $\begin{array}{l}\frac{.}{\bar{\Xi}} \\
\text { हूँ }\end{array}$ & 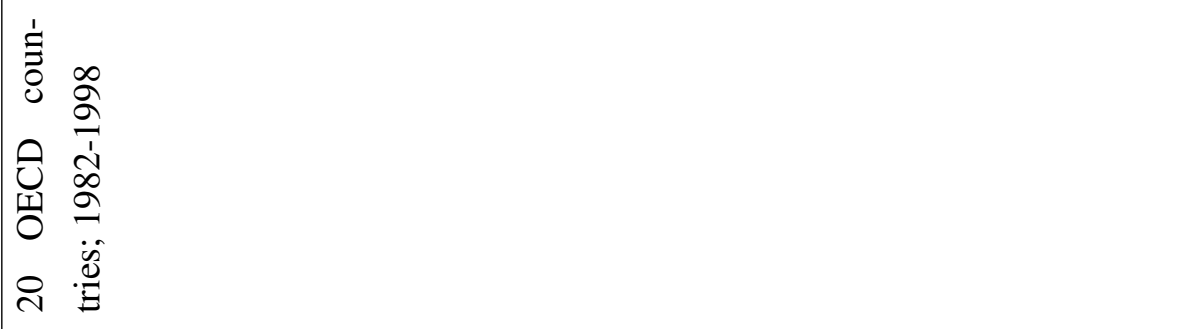 & 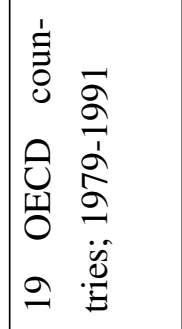 \\
\hline 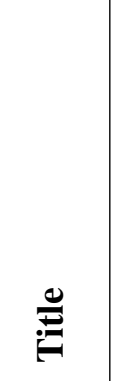 & 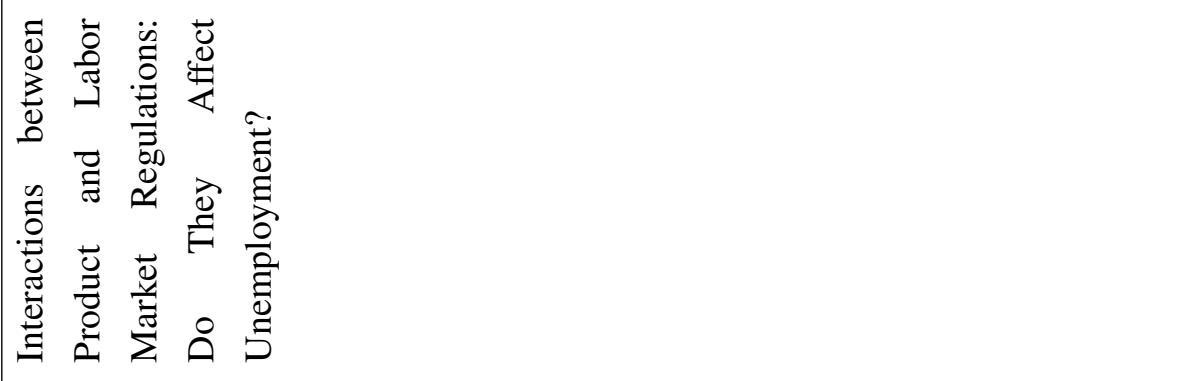 & \\
\hline 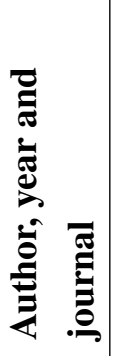 & 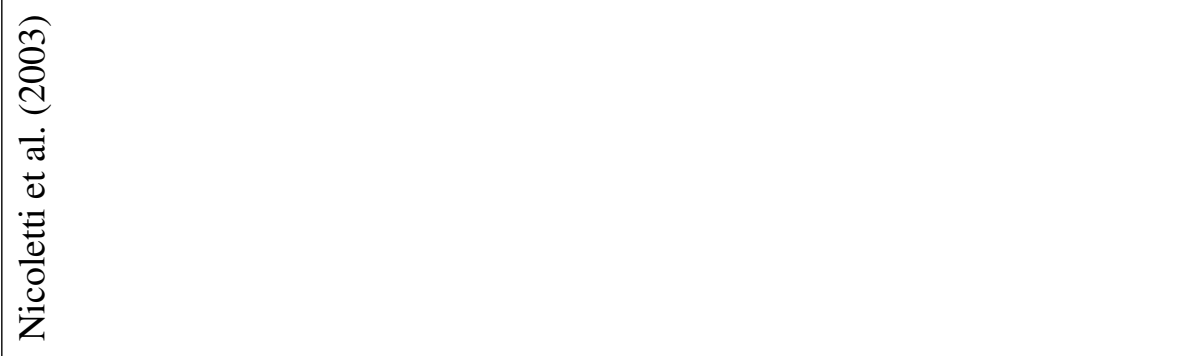 & $\begin{array}{l}\widehat{\widehat{\Omega}} \\
\hat{\sigma} \\
\stackrel{0}{0} \\
\text { İ }\end{array}$ \\
\hline
\end{tabular}




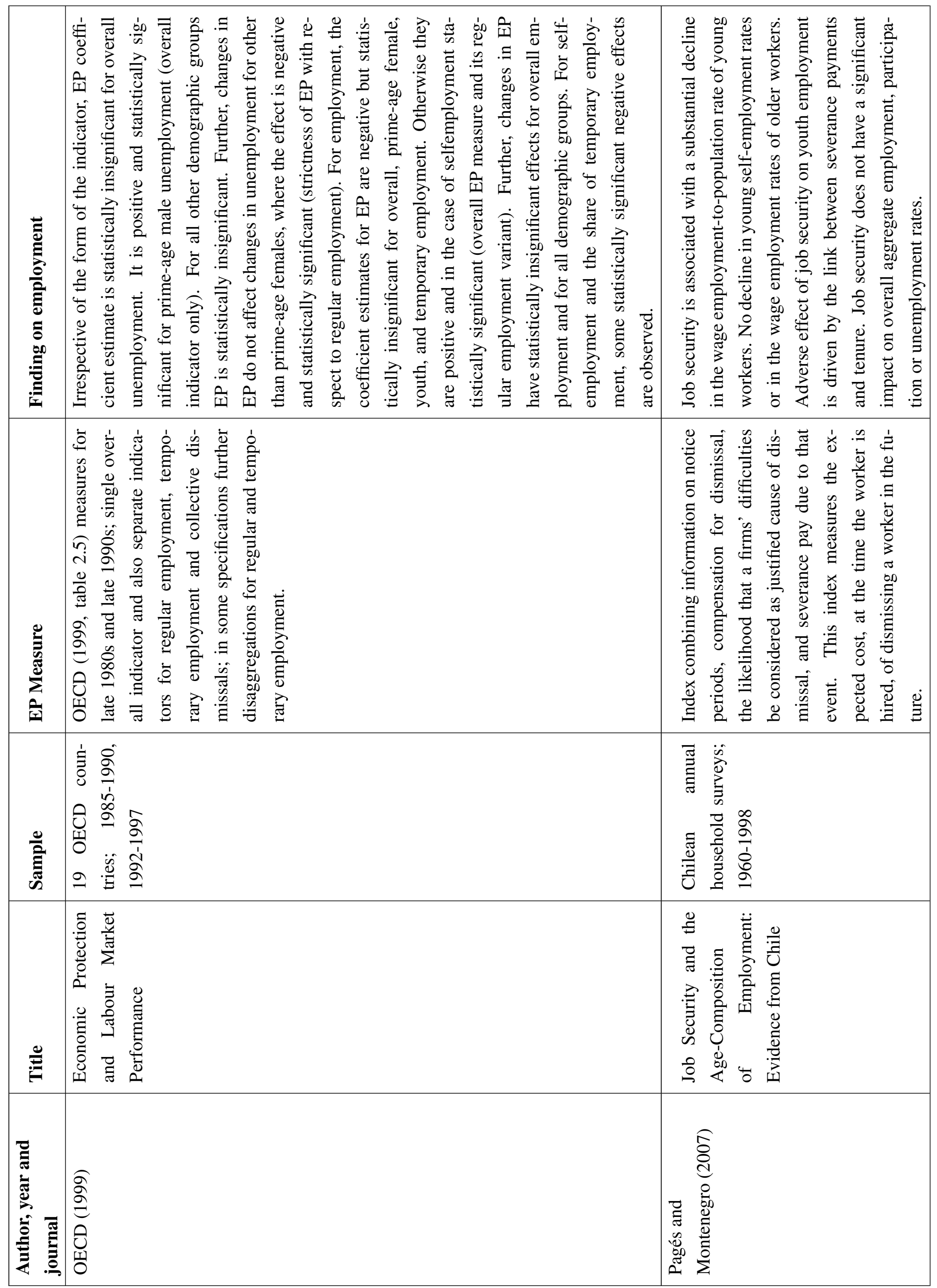




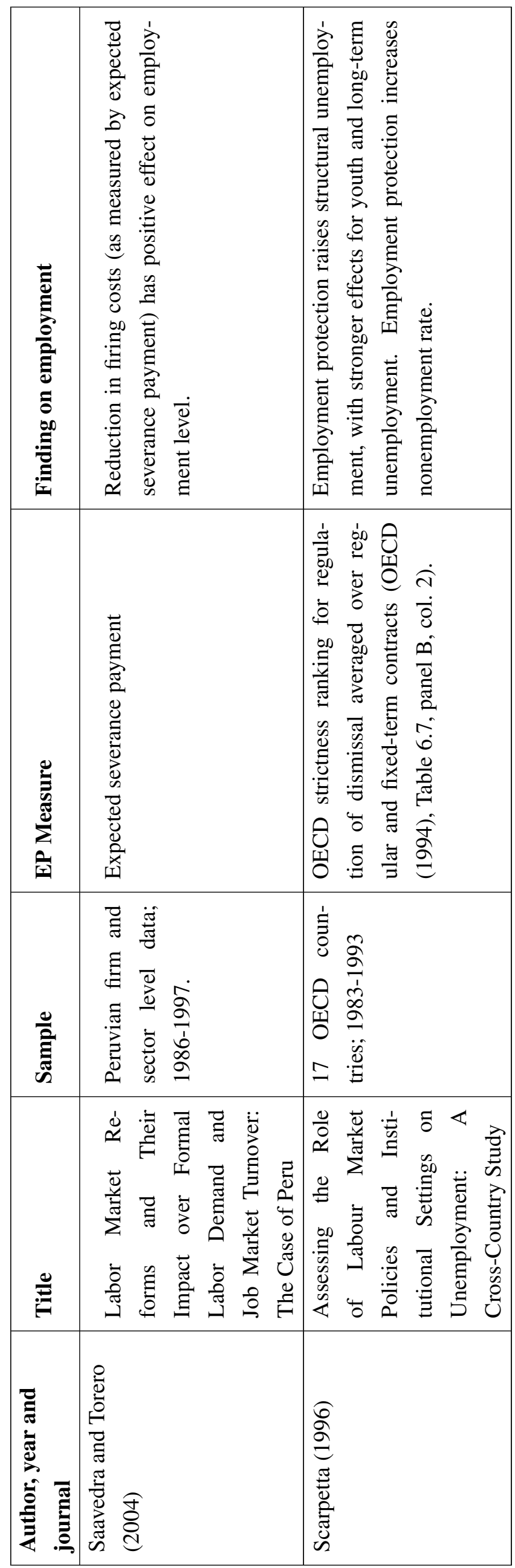




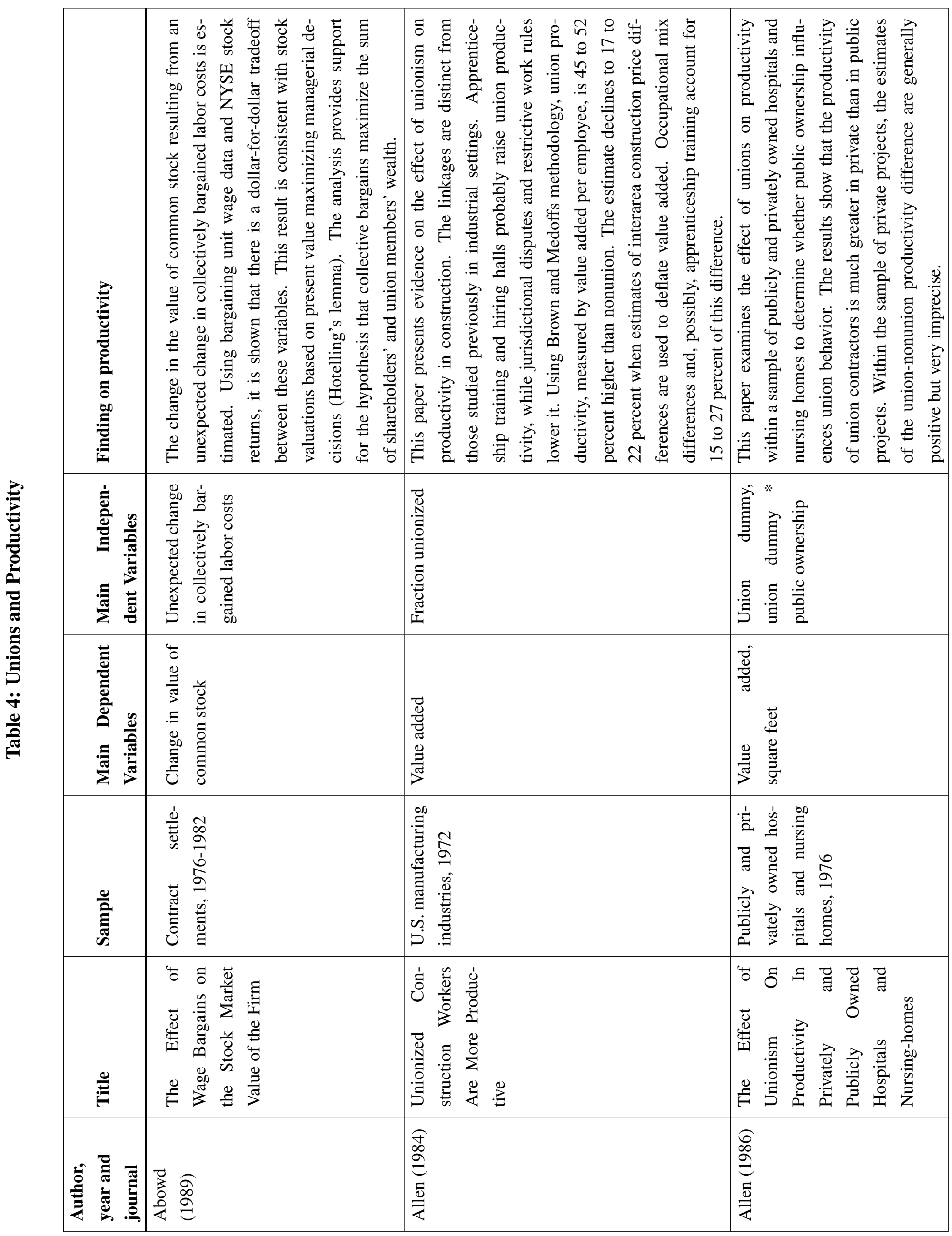




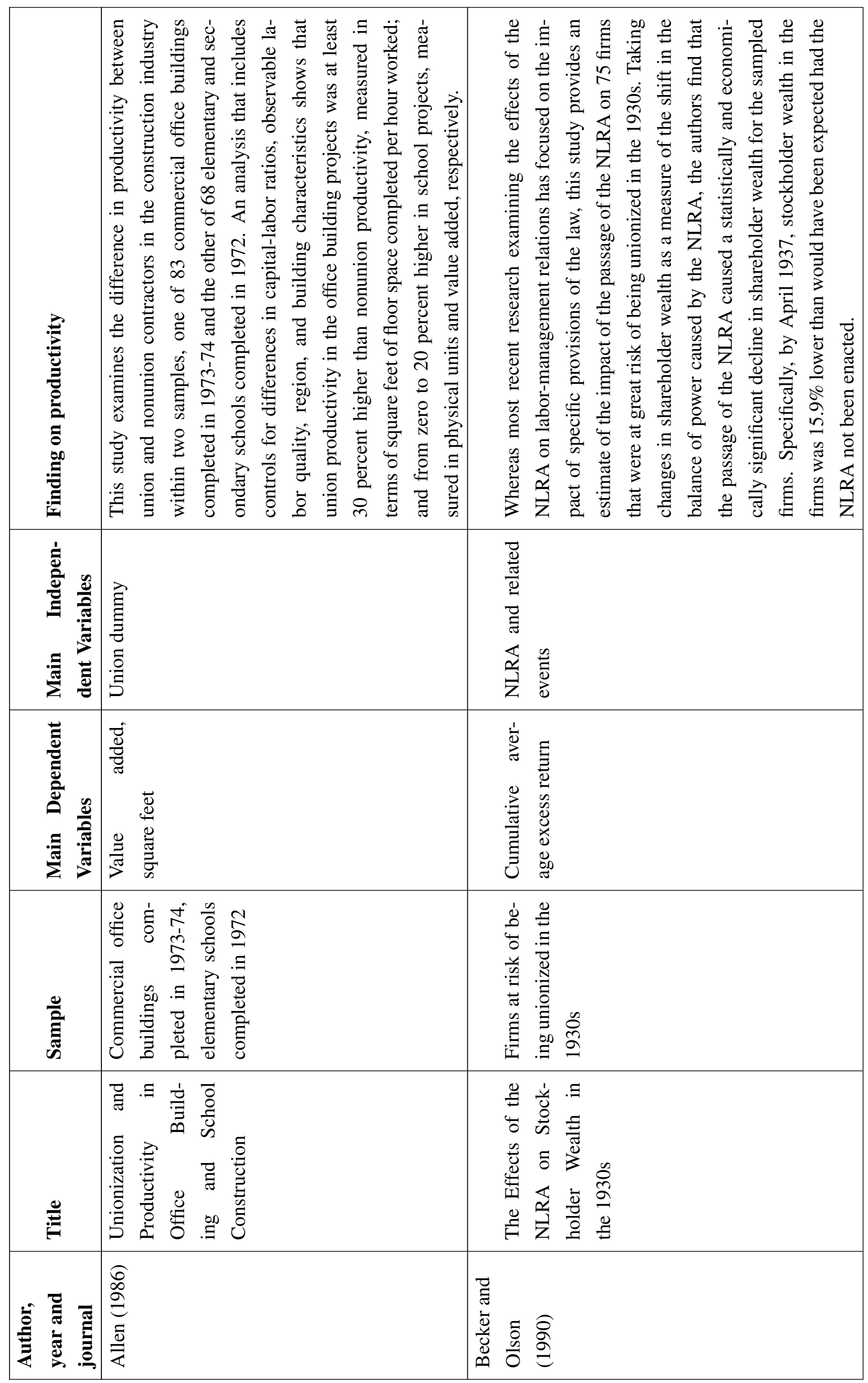




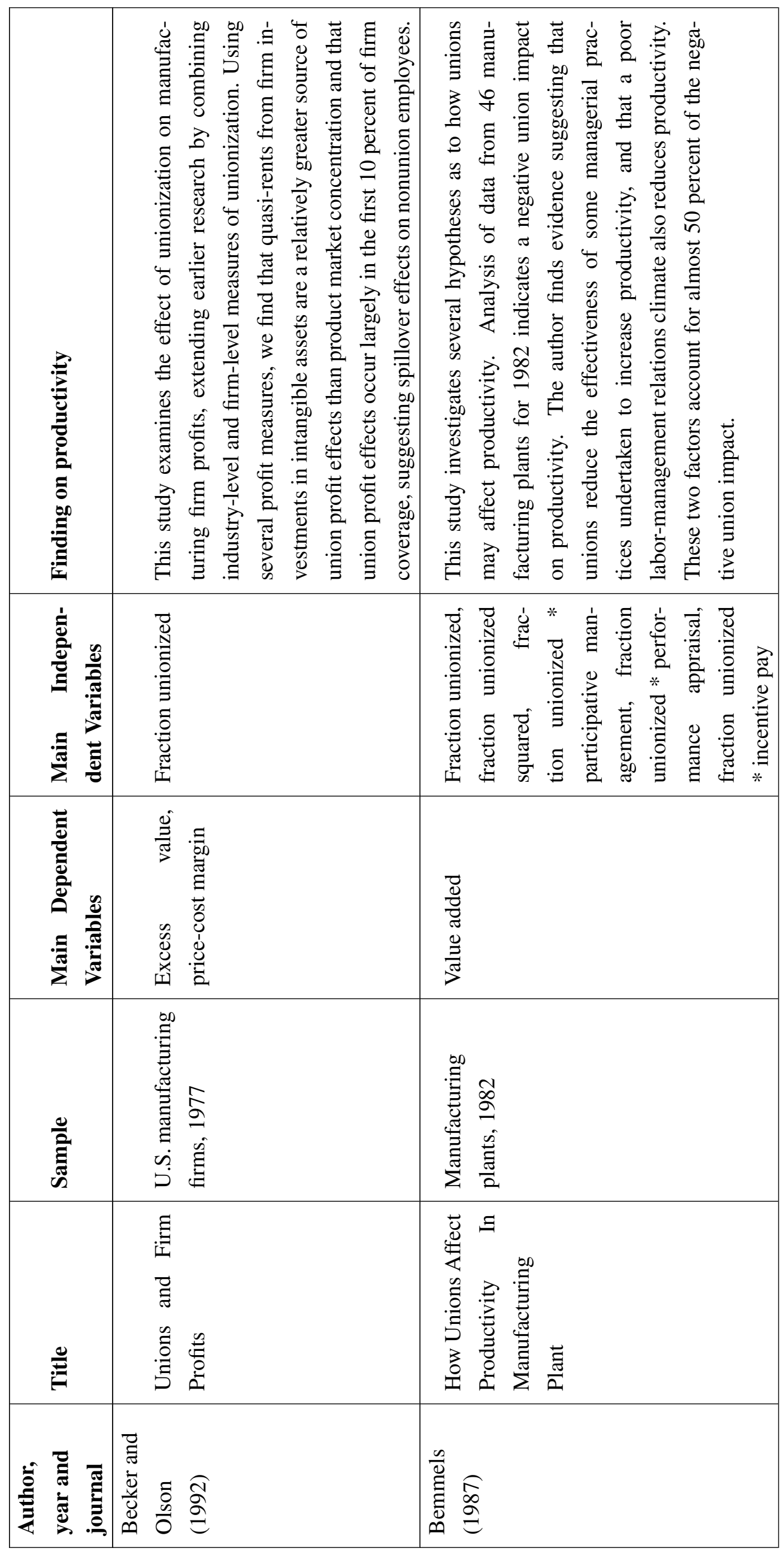




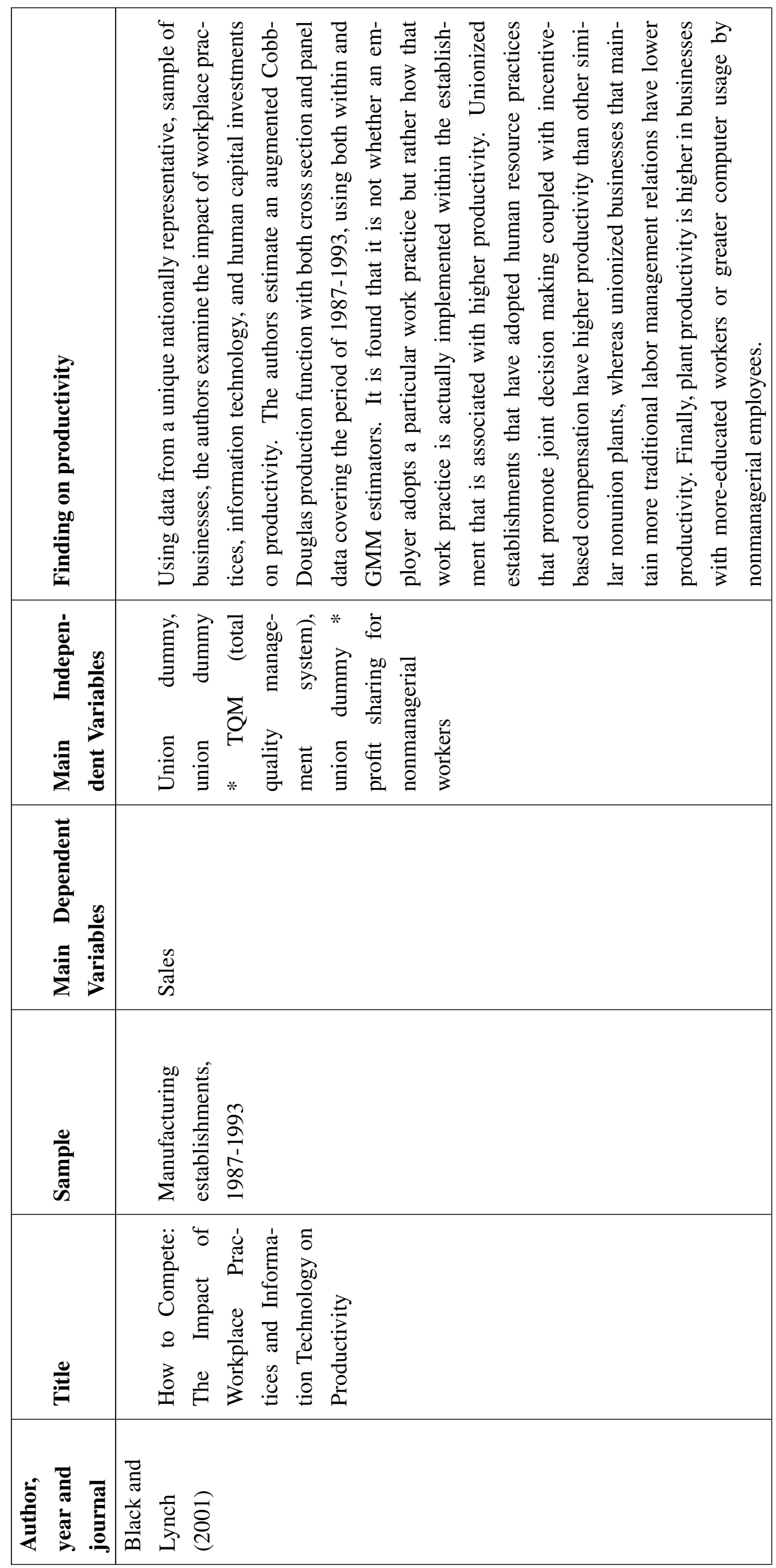




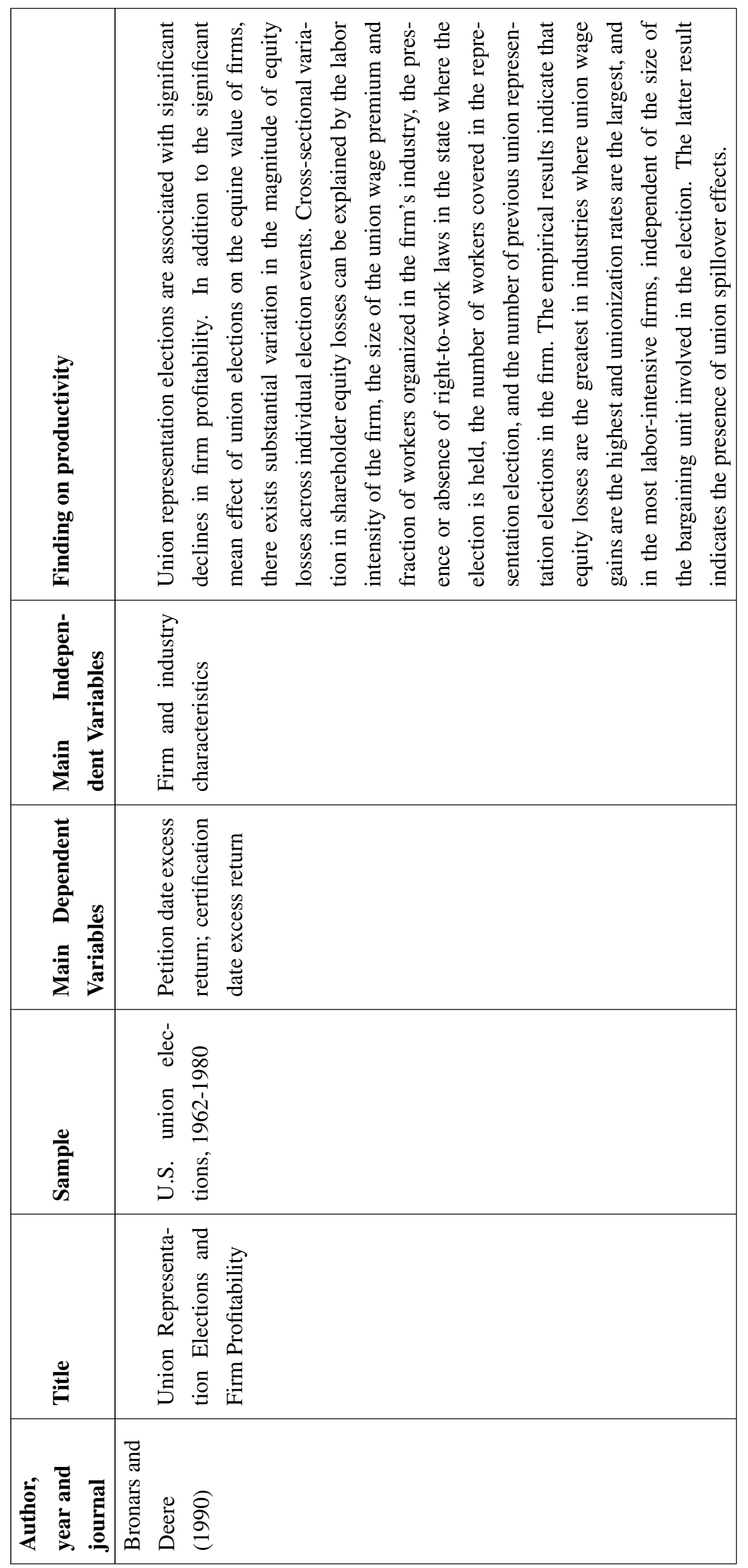




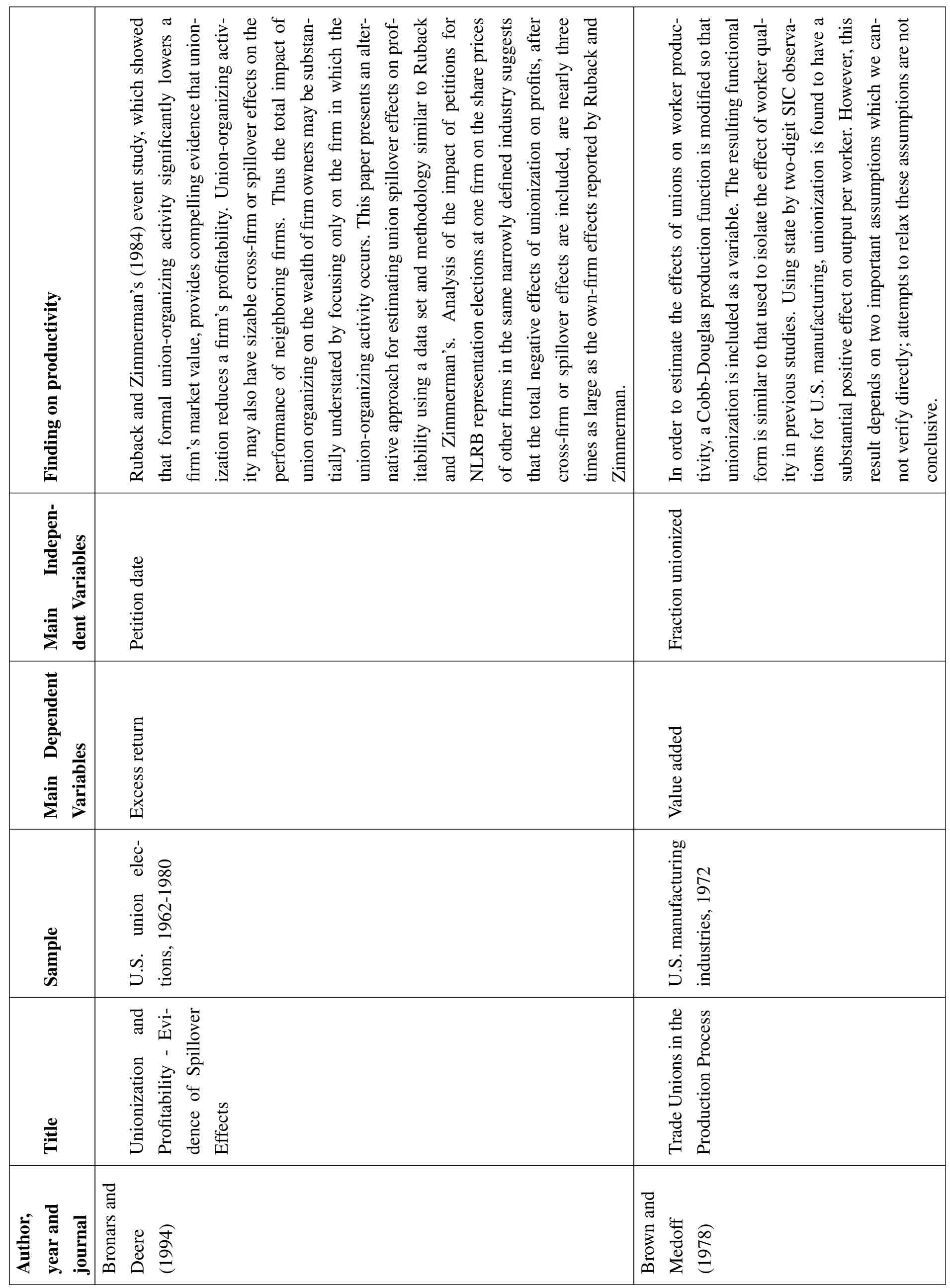




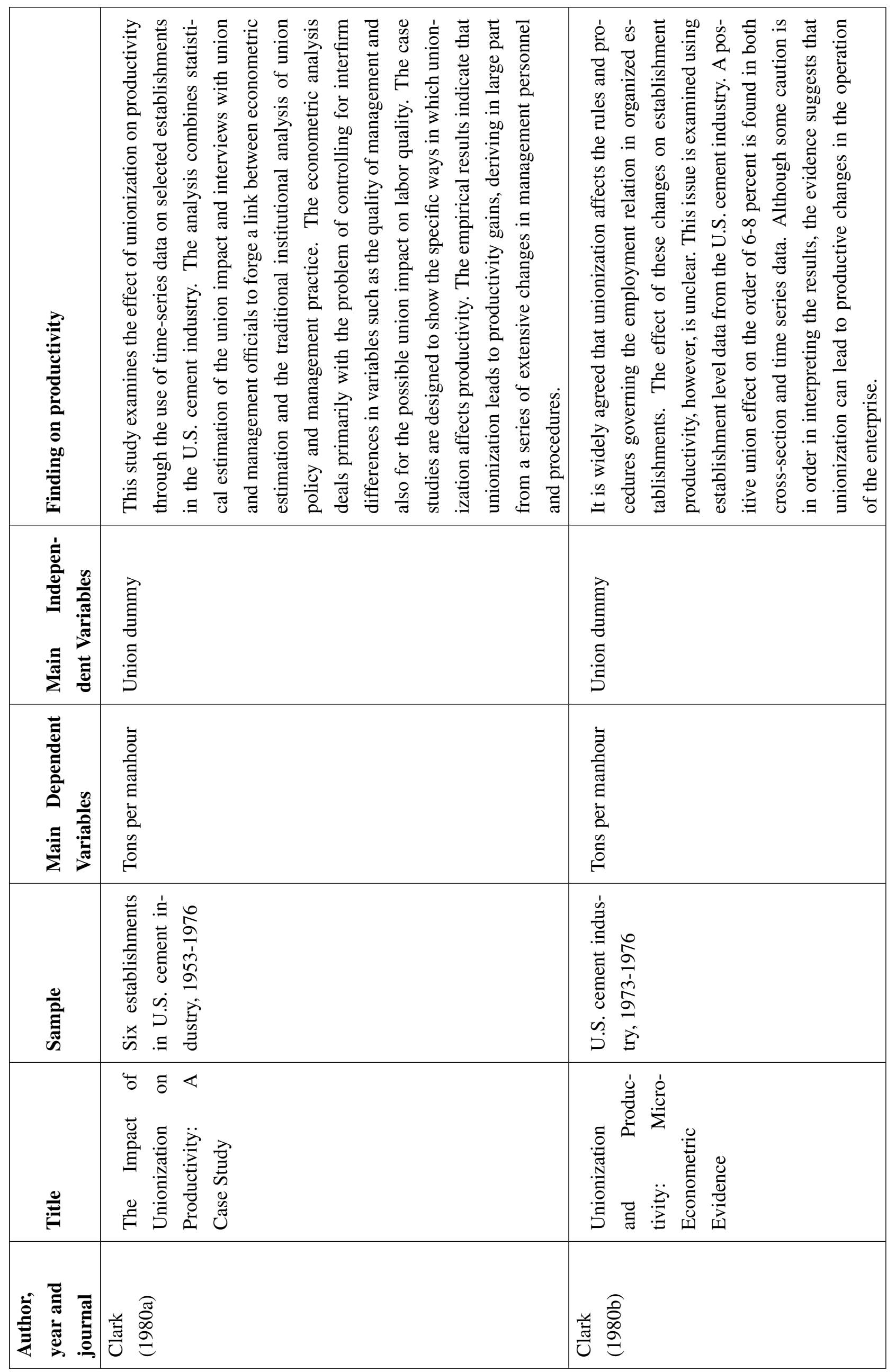




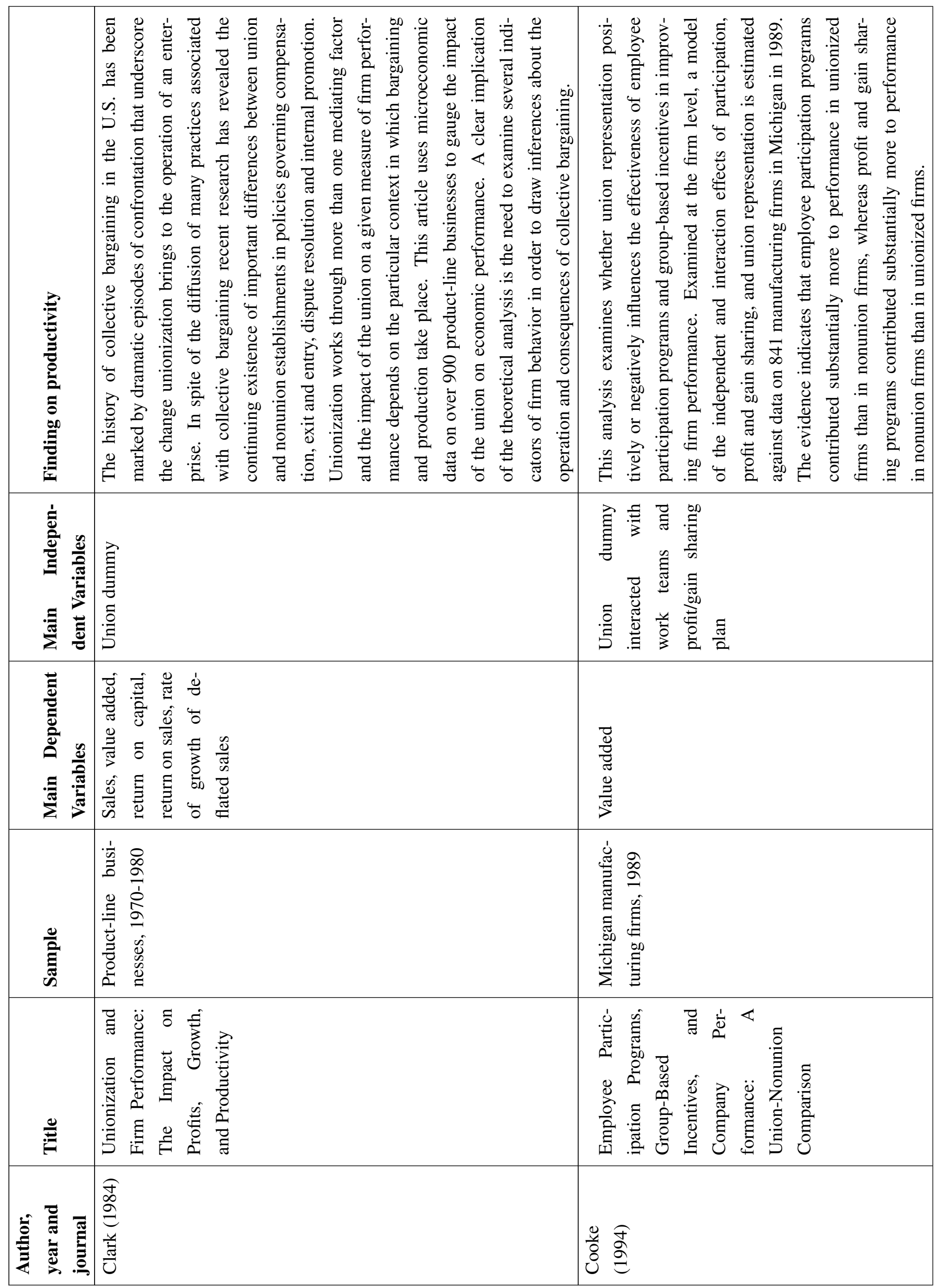




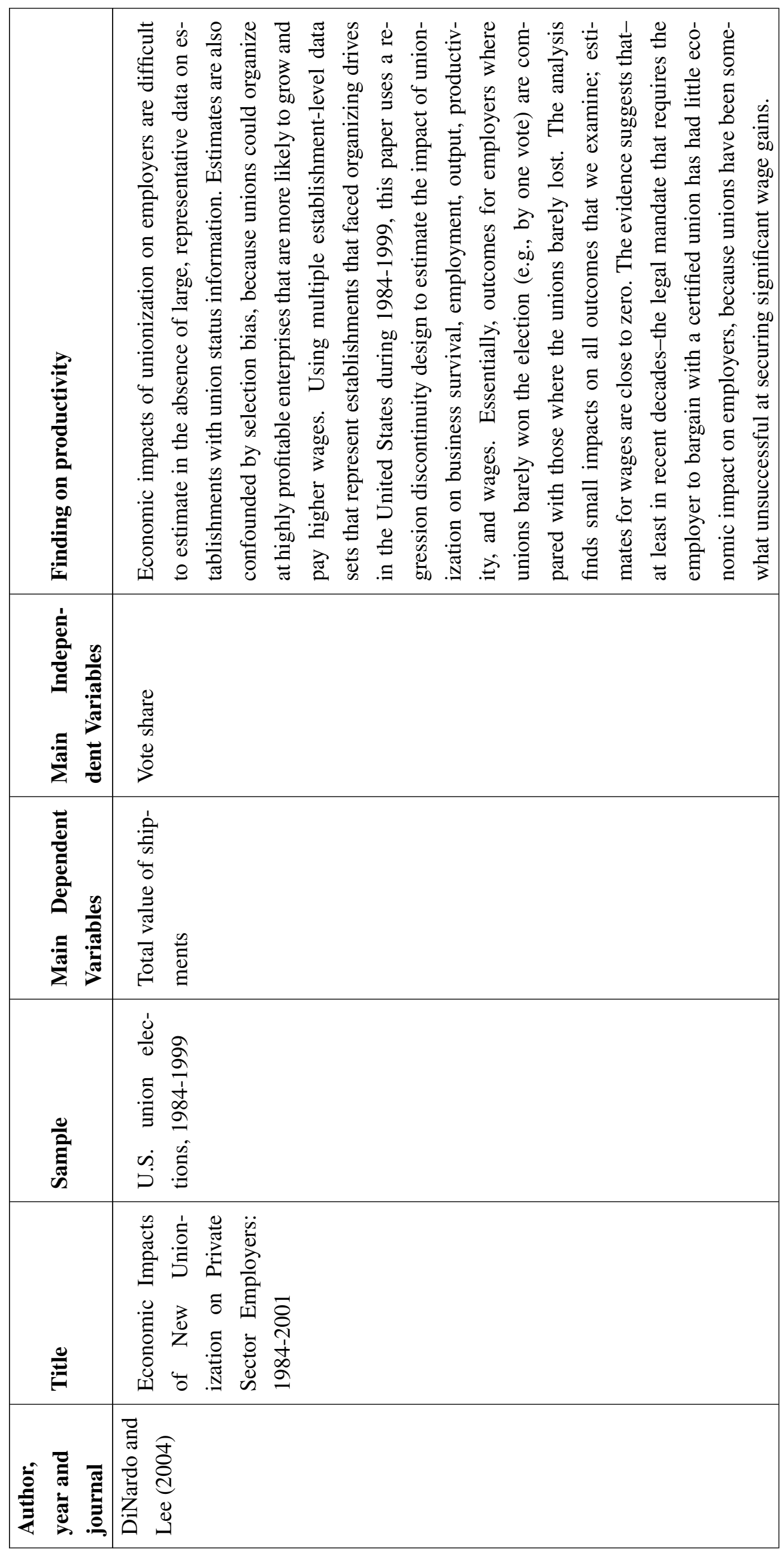




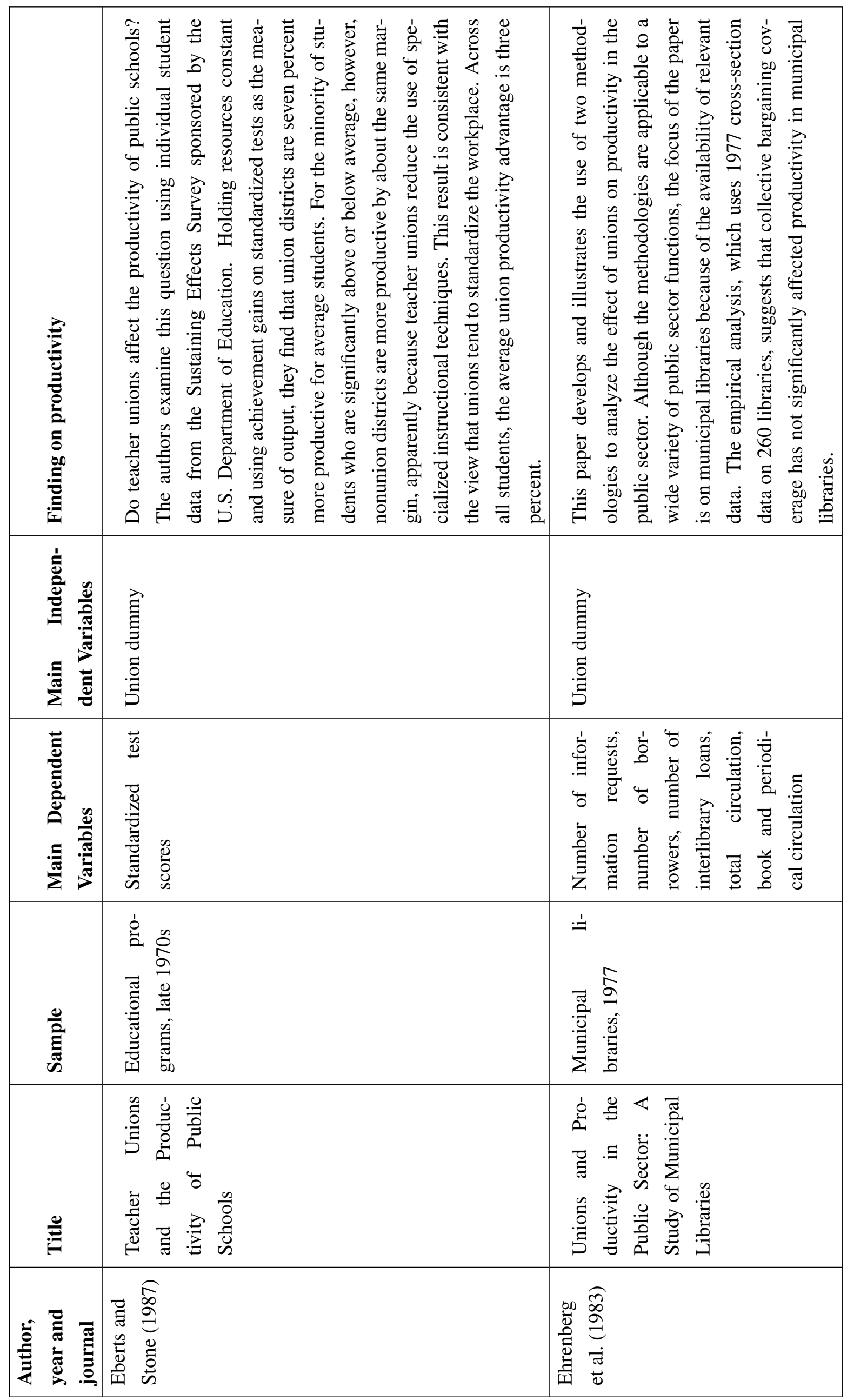




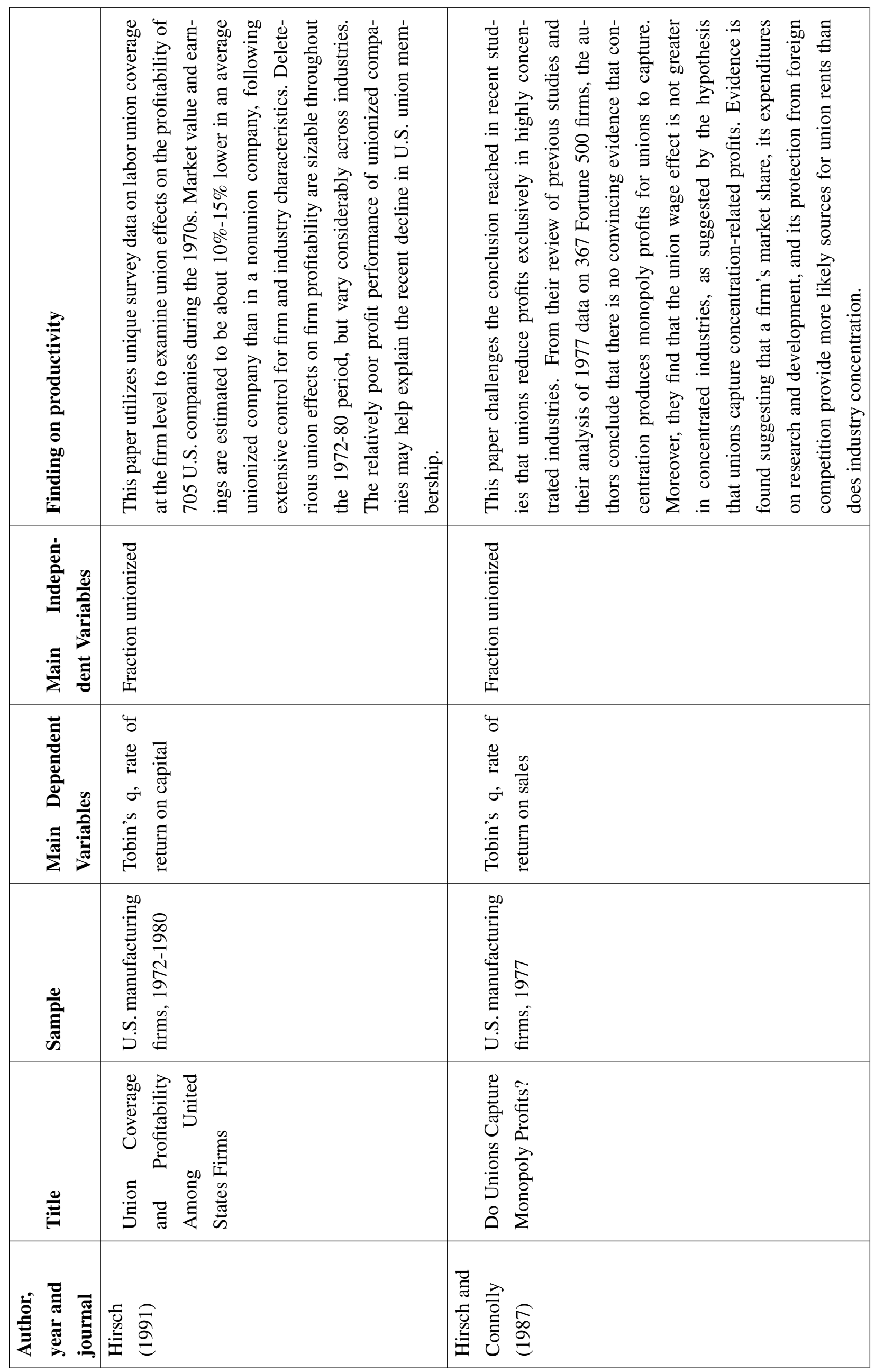




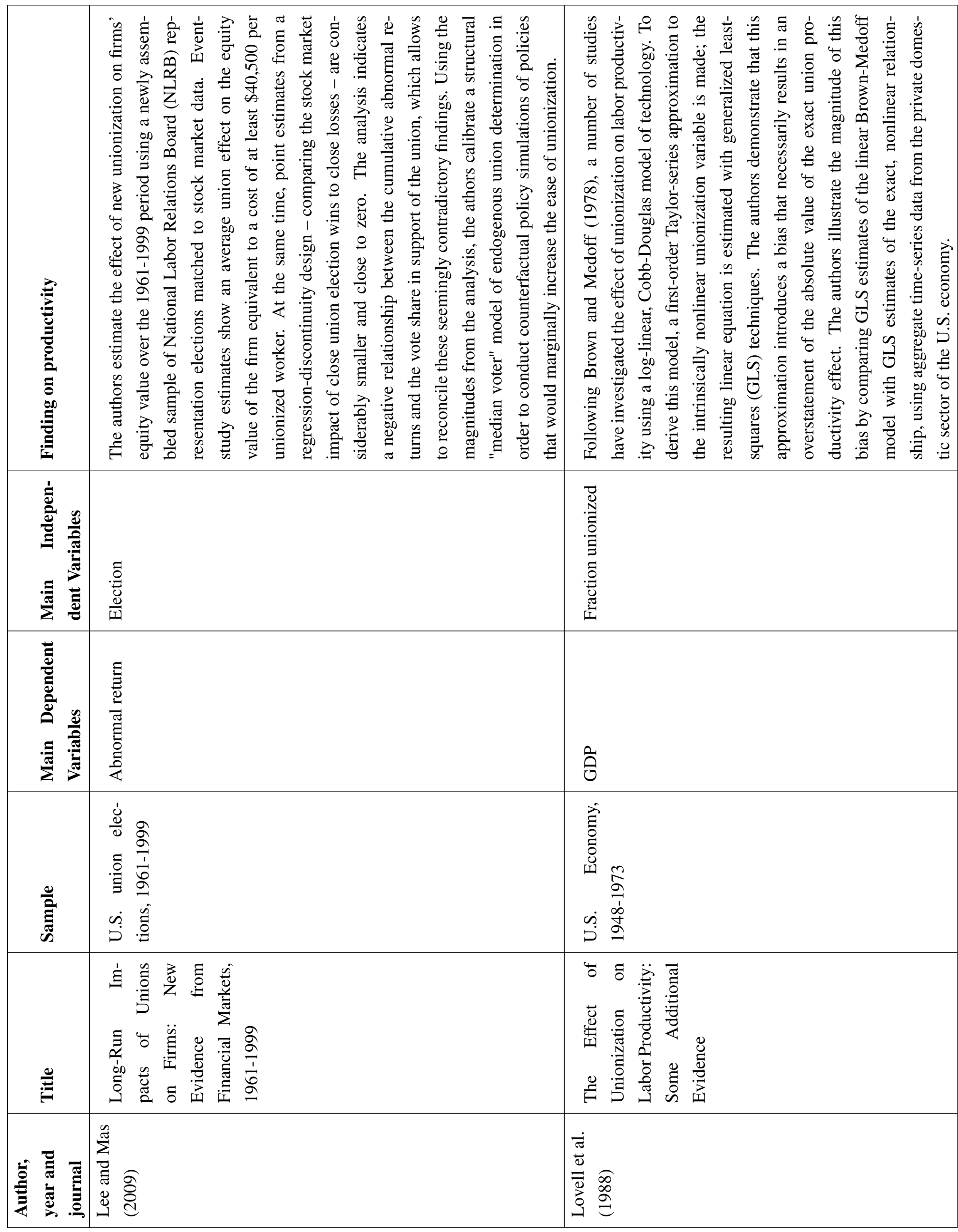




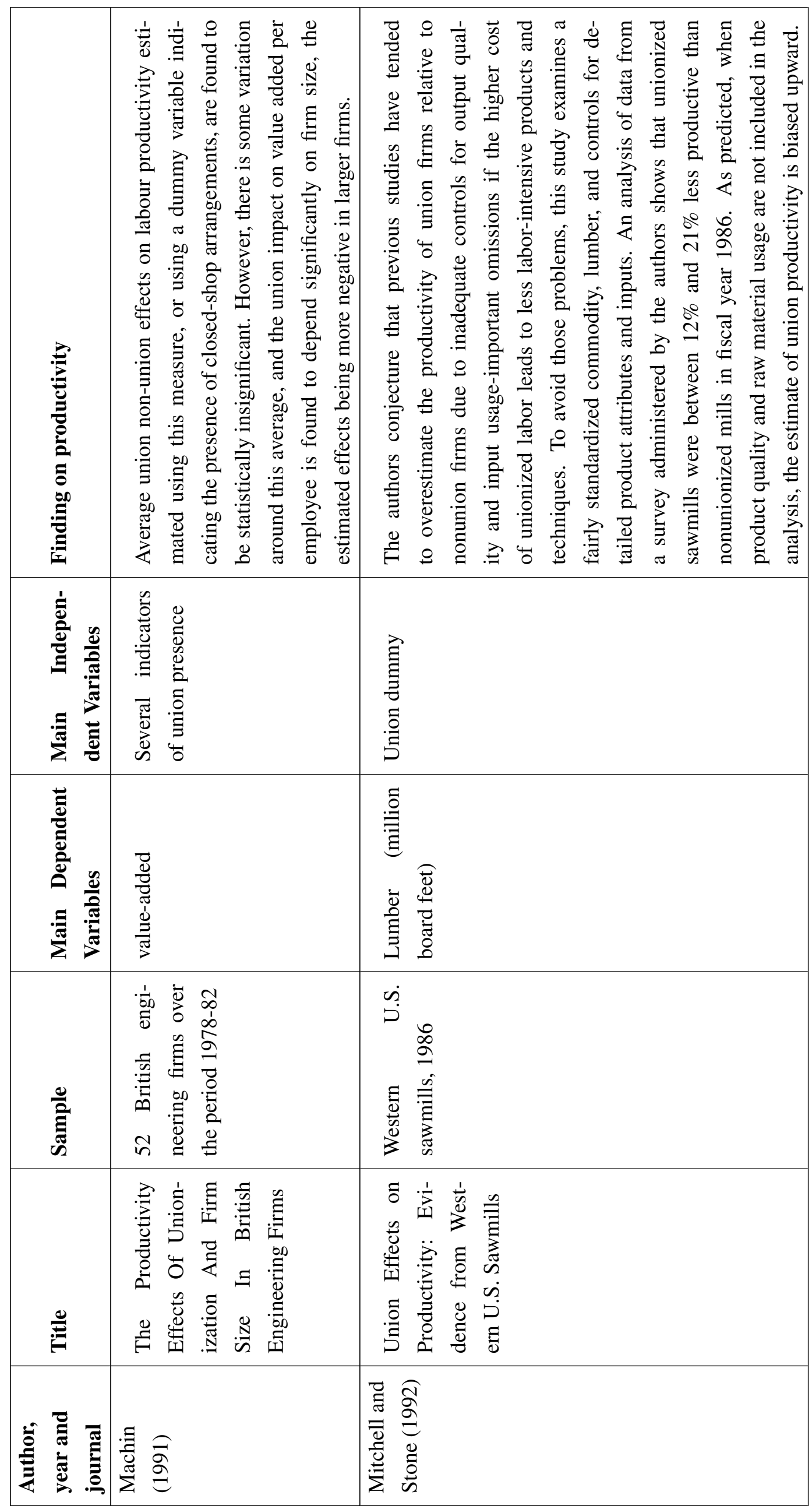




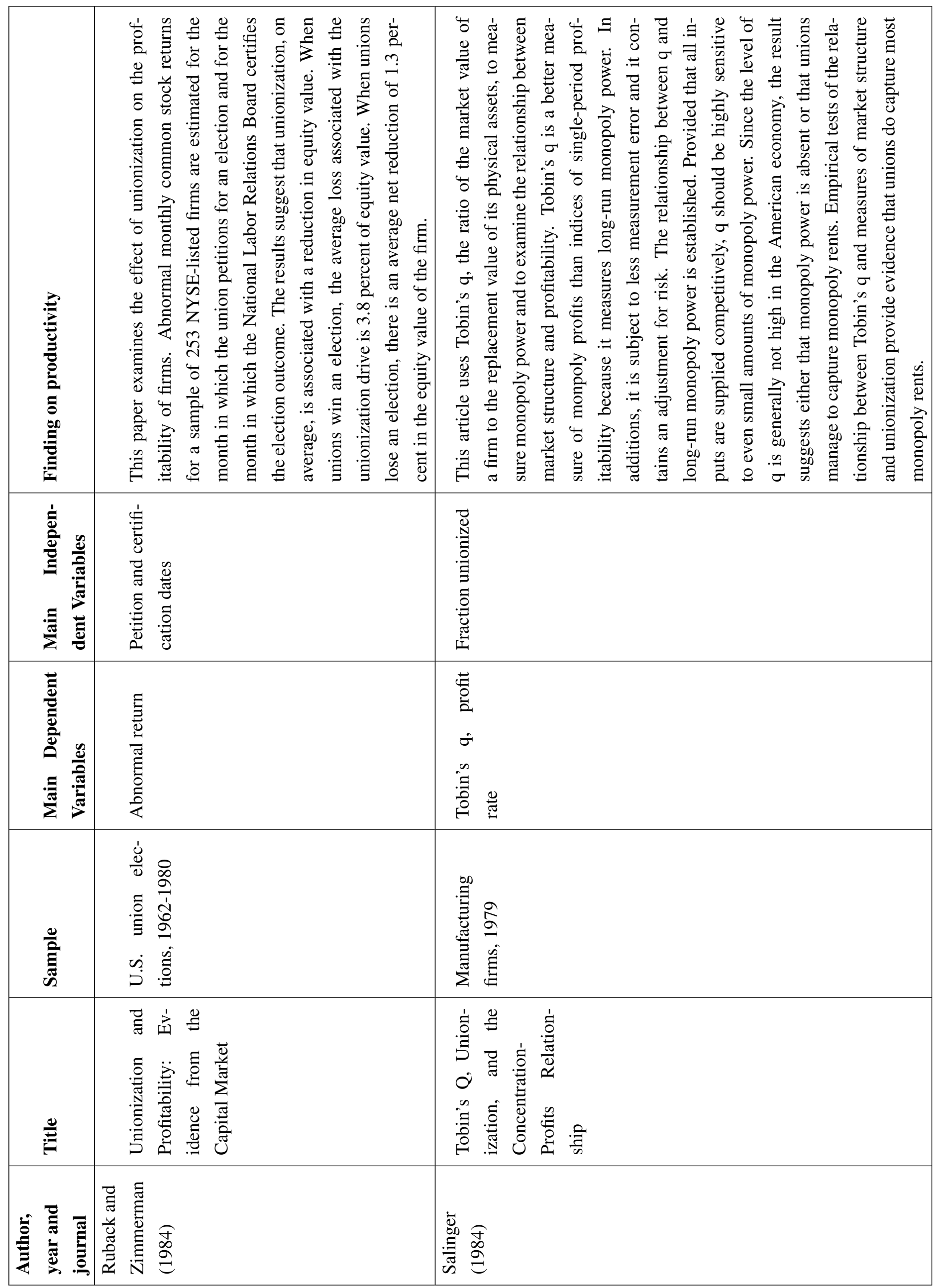




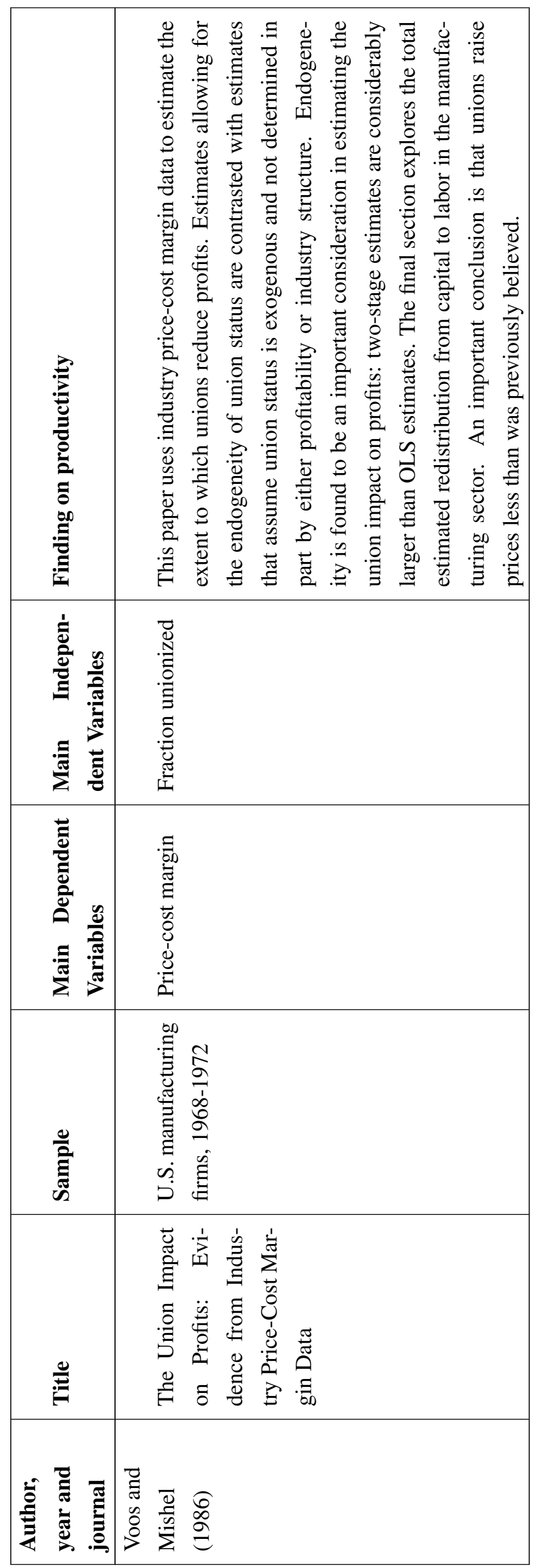

